FLÁVIO ROCHA LIMA PARANHOS

CRÍTICA À TEORIA DA MORALIDADE COMUM COMO FUNDAMENTAÇÃO DO PRINCIPIALISMO

BRASILÍA - DF 


\author{
UNIVERSIDADE DE BRASÍLIA \\ FACULDADE DE CIÊNCIAS DA SÁUDE \\ PROGRAMA DE PÓS-GRADUAÇÃO EM BIOÉTICA
}

FLÁVIO ROCHA LIMA PARANHOS

\title{
CRÍTICA À TEORIA DA MORALIDADE COMUM COMO FUNDAMENTAÇÃO DO PRINCIPIALISMO
}

\author{
Tese apresentada como requisito parcial à \\ obtenção do título de Doutor em Bioética \\ pelo Programa de Pós-Graduação em \\ Bioética da Universidade de Brasília - \\ Linha de Pesquisa: Fundamentos de \\ Bioética e Saúde Pública. \\ Orientador: Prof. Dr. Volnei Garrafa
}

BRASÍLIA - DF 


\title{
FLÁVIO ROCHA LIMA PARANHOS
}

\section{CRÍTICA À TEORIA DA MORALIDADE COMUM COMO FUNDAMENTAÇÃO DO PRINCIPIALISMO}

\author{
Tese apresentada como requisito parcial à \\ obtenção do título de Doutor em Bioética \\ pelo Programa de Pós-Graduação em \\ Bioética da Universidade de Brasília - \\ Linha de Pesquisa: Fundamentos de \\ Bioética e Saúde Pública.
}

Apresentação em 11 de dezembro de 2015.

\section{BANCA EXAMINADORA}

Prof. Dr. Volnei Garrafa (Presidente)

Universidade de Brasilia

Prof. Dr. Gabriele Cornelli

Universidade de Brasilia

Prof. Dr. Wanderson Flor do Nascimento Universidade de Brasilia

Profa. Dra. Ondina Pena Pereira

Universidade Católica de Brasília

Prof Dr. Márcio Fabri dos Anjos

Centro Universitário São Camilo - São Paulo 


\section{RESUMO}

A proposta epistemológica para uma ética biomédica de Tom L. Beauchamp e James F. Childress está contida em sua principal obra, Principles of Biomedical Ethics, atualmente em sua sétima edição (2013). Em resposta a críticas surgidas na década de 1990, os autores introduziram, a partir da quarta edição (1994), sua teoria da moralidade comum como fundamentação de seus princípios. Também esta teoria passou a ser alvo de muitas críticas, questionando até mesmo a possibilidade de existência de uma moralidade comum. A proposta do presente trabalho é, num primeiro momento, discutir a teoria destes autores, assim como de outros que exerceram influência mais direta sobre eles, tais como Bernard Gert, Alan Donagan e W.D. Ross. A seguir são apresentadas algumas abordagens críticas ao principialismo e/ou à teoria da moralidade comum. Então, são discutidas também outras propostas de moralidade comum, incluindo algumas que não se valeram deste termo, mas de outros, tais como "ética verdadeira", "ética natural", ou, ainda, simplesmente "ética". A constatação que se segue a partir da análise tanto das propostas de moralidade comum, como de suas abordagens críticas é a de que não existe uma moralidade comum. O que determinará o comportamento moral será a adesão voluntária a um sistema específico de normas que cada um desejar para si. Vários autores se deram conta dessa dificuldade, e contentam-se com um mínimo, um item básico que pode ser o "respeito mútuo", ou "não causar dor/sofrimento" ou, simplesmente, "diálogo". Mas fica logo evidente que este mínimo é pouco demais, insatisfatório para, efetivamente, solucionar os problemas reais que se apresentam, tanto no terreno mais restrito da ética biomédica, quanto no mais amplo, da bioética. A busca por uma moralidade comum, mesmo com outros nomes, mostrar-se-á sempre infrutífera. Ou não será "comum", ou não será "moralidade". Diante disso, conclui-se pela adequação de uma proposta que, sem desconsiderar a natureza humana, não terá esta como ponto de partida para o estabelecimento de normas, que serão sempre circunstanciais em relação a um objetivo específico. Uma ética de imperativos hipotéticos, bem distantes da moralidade comum principialista. A decisão final deve sempre levar em consideração o maior bem para o maior número de pessoas, exceto quando isso acarretar prejuízo significativo para uma determinada minoria particularmente vulnerável, que, neste caso, deverá receber a intervenção afirmativa do Estado. Tal conclusão leva à opção pela proposta de Garrafa e Porto, da "Bioética Dura", cujo papel seria o de arbitrar e intervir, sempre que necessário.

Palavras-chave: Bioética; Principialismo; Fundamentação Filosófica; Teoria da Moralidade Comum. 


\begin{abstract}
The epistemological proposal for a biomedical ethics of Tom L. Beauchamp and James F. Childress is presented in their main work, Principles of Biomedical Ethics, currently in its seventh edition (2013). In response to criticisms that have emerged in the years 1990, the authors introduced in the fourth edition (1994), their theory of common morality as justification of their principles. This theory also became the target of much criticism, questioning even the possibility of the existence of a common morality. The proposal of this work is, at first, to discuss the theory of these authors, as well as others who exercised most direct influence on them, such as Bernard Gert, Alan Donagan and W.D. Ross. Subsequently, some critical approaches to principlism and/or the theory of common morality presented and discussed. Then we analyze other proposals of theories of common morality, including some that do not make use of this term, but others, such as "true" ethics, "natural ethics", or simply "ethics". The conclusion that follows from the analysis of both the proposals of common morality, as well as their critical approaches is that there is no such thing as a common morality. What determines the moral behavior is the voluntary adhesion to a specific system of standards that each one chooses to follow. Many authors became aware of this difficulty, and settled for a minimum, a basic item that can either be "mutual respect", or "don't cause pain/suffering" or simply "dialogue". However, it soon becomes evident that this minimum is unsatisfactory to effectively solve the real problems that present themselves, both in the narrower field of biomedical ethics, or of bioethics in general. The search for a common morality, even with other names, will always prove itself fruitless. Either it will not be "common", or it will not be a "morality". Given this, we conclude for the appropriateness of a proposal that, without disregard to human nature, will not have this as a starting point for the establishment of norms, which will always be circumstantial in relation to a specific goal. It will be an ethics of hypothetical imperatives, significantly different from the principlist common morality. The final decision should always take into consideration the greatest good for the greatest number of people, except when that may cause significant injury to a certain particularly vulnerable minority, which, in this case, must receive the affirmative intervention by the state. This conclusion leads to the option by the proposal of Garrafa and Porto, "Hard Bioethics", whose role would be to mediate and intervene whenever necessary.
\end{abstract}

Keywords : Bioethics; Principlism; Philosophical Reasoning; Theory of Common Morality. 


\section{SUMÁRIO}

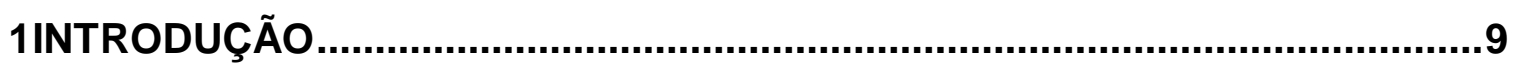

2TEORIAS ÉTICAS COM FUNDAMENTAÇÃO NA MORALIDADE COMUM ..12

\subsection{A TEORIA DA MORALIDADE COMUM DE BERNARD GERT ...............12}

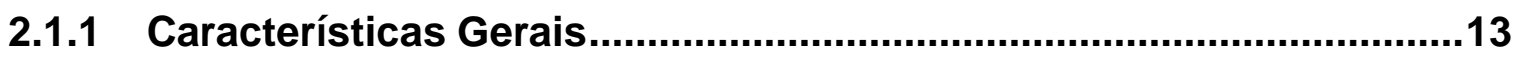

2.1.2 O Sistema Moral de Bernard Gert ..................................................14

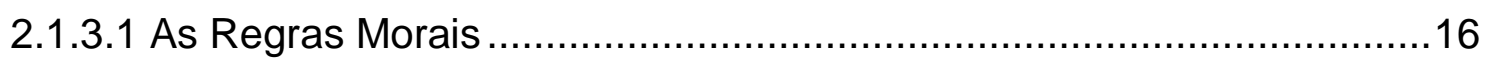

2.1.3.2 A Quem se Aplicam as Regras Morais? ..........................................18

2.1.3.3 Violando as Regras Justificadamente ............................................19

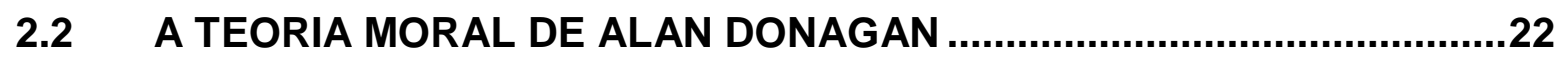

2.2.1 Uma teoria moral é uma teoria de quê? ...........................................22

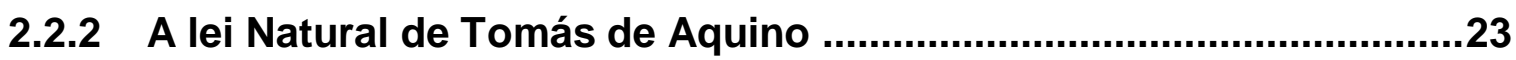

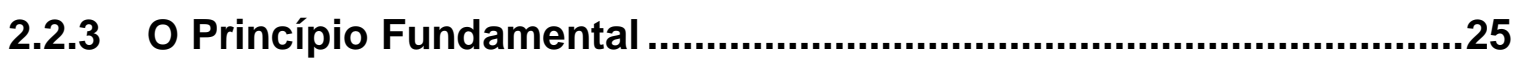

2.2.3.1 A Classificação dos Preceitos de Primeira Ordem ...............................26

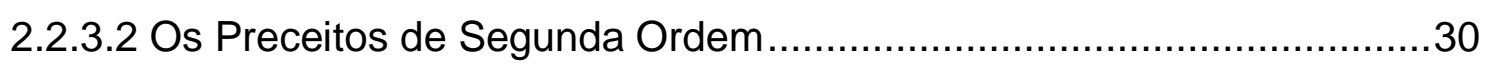

2.2.4 Consistência da Proposta Para uma Teoria Moral de Alan Donagan 31

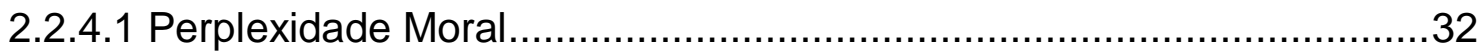

2.2.4.2 Fazer o Mal para Alcançar o Bem .................................................... 34

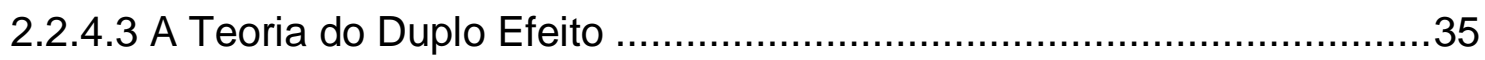

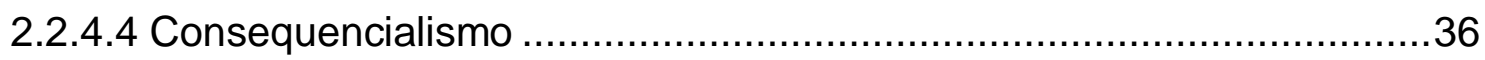

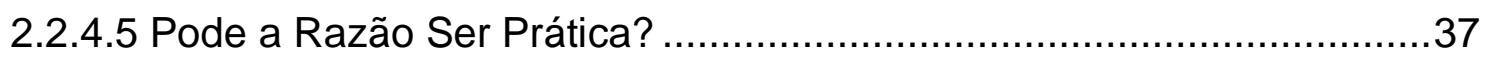

2.3 A TEORIA MORAL DE WILLIAM DAVID ROSS ...................................39

2.3.1 Definições Naturalísticas de "Correto" .............................................40

2.3.2 Definições Não Naturalísticas de 'Correto' .........................................42

2.3.2.1 Obrigações Prima Facie ............................................................... 44

3 A TEORIA DA MORALIDADE COMUM DE BEAUCHAMP E CHILDRESS 50

3.1.1 Moralidade comum como moralidade universal ..................................50

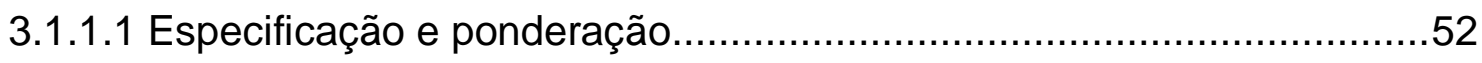

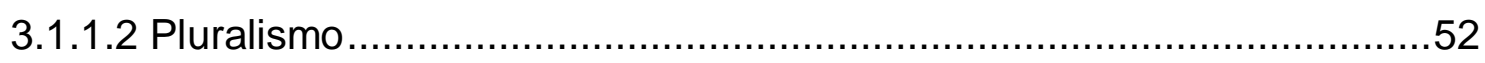

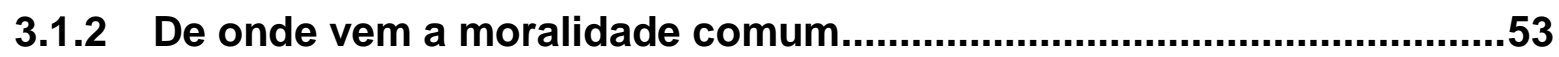

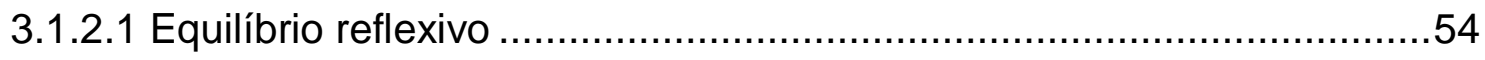


3.1.2.2 Existe mesmo uma moralidade comum?

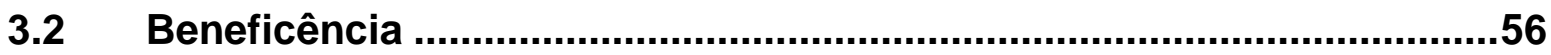

3.2.1 O princípio da beneficência aplicado à pesquisa biomédica ................57

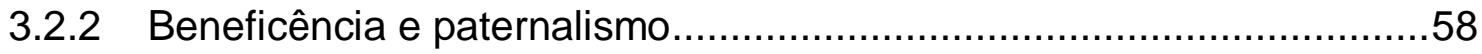

3.2.3 Beneficência versus autonomia delegada .....................................60

3.2.4 Benefício versus custo .............................................................60

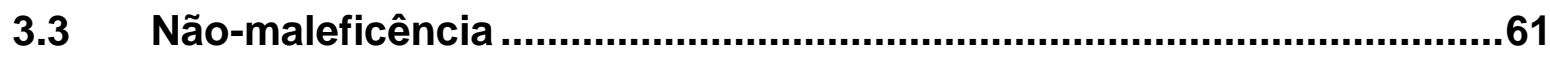

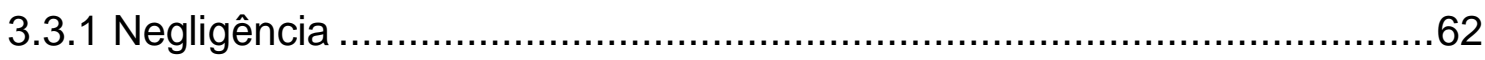

3.3.2 Não-maleficência e ética em pesquisa...........................................62

3.3.3 Deixar de fazer e retirar (interromper) tratamento ...............................63

3.3.4 A regra (doutrina, princípio, teoria) do duplo efeito ............................64

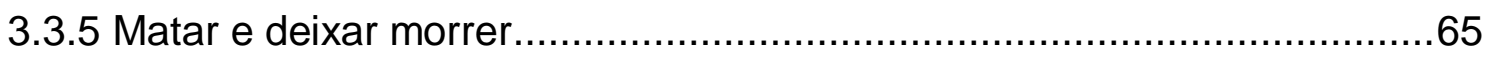

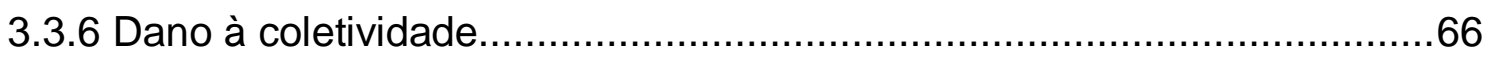

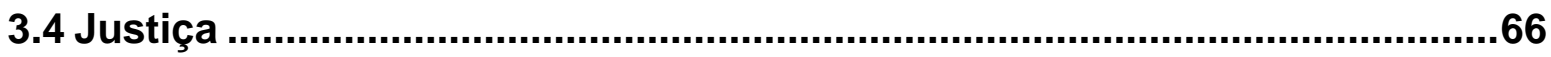

3.4.1 Oportunidades iguais, discriminação injusta ................................67

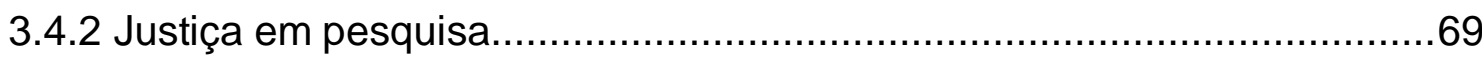

3.4.3 Política Nacional de Saúde .....................................................................70

3.4.4 Alocando, priorizando e racionando recursos ................................71

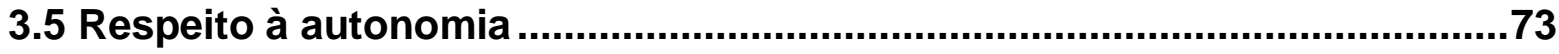

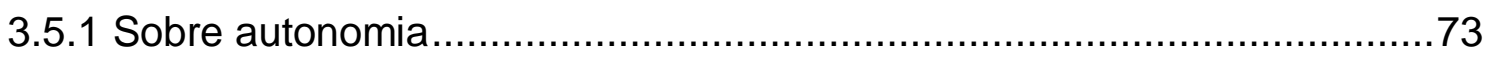

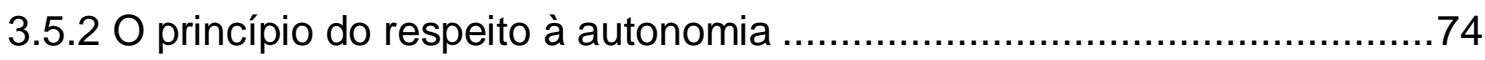

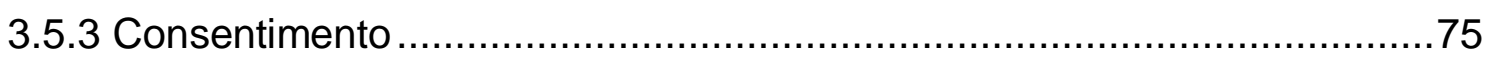

4 CRÍTICAS À MORALIDADE COMUM ........................................................77

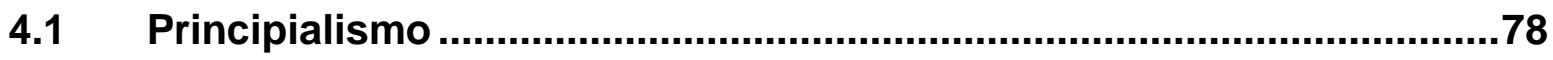

4.2 Fragilidades de uma moral intuitiva do senso comum ........................79

4.3 Questões para o método do equilíbrio reflexivo...................................82

4.4 0 princípio do respeito à autonomia como ponto frágil .......................88

4.5 As críticas ao Principialismo pela persectiva latino-americana...........89 
5 DISCUSSÃO. .96

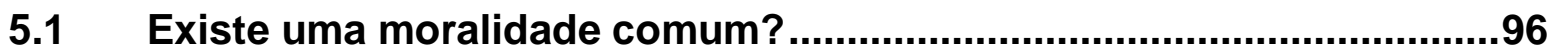

5.2 Do que falamos, quando falamos de moralidade comum? ...................97

5.3 Moralidade comum com outro nome .................................................101

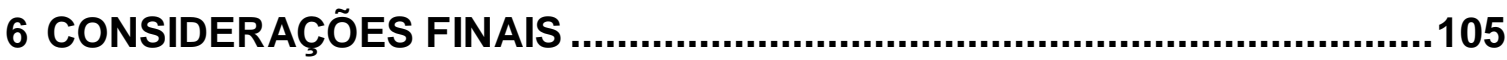

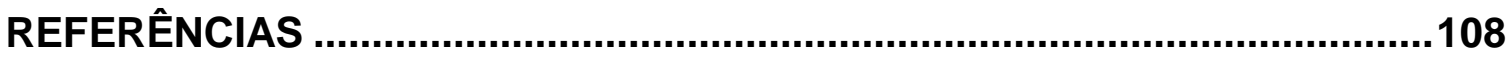




\section{INTRODUÇÃO}

Principles of Biomedical Ethics (1), a principal obra de Tom L. Beauchamp e James F. Childress, está em sua sétima edição. A primeira data de 1979 , com as seguintes nos anos de 1983, 1989, 1994, 2001, 2009, até a atual, de 2013. Segue influenciando o pensamento bioético mundial como quando foi publicada pela primeira vez. São aproximadamente quarenta anos de uma hegemonia epistemológica impressionante. Creditar isso apenas ao fato de que se trata de uma obra com origem nos Estados Unidos seria um erro. Embora seja verdade que a hegemonia político-econômica do país exerça sua força em todos os campos do conhecimento, abrindo o caminho para iniciativas vindas de lá, há sempre a necessidade de que algum mérito esteja por trás.

O principal mérito de Principles of Biomedical Ethics é sua simplicidade intuitiva. Beauchamp e Childress (1) valeram-se de princípios norteadores da interação entre pacientes e profissionais da saúde, notadamente médicos, que já estavam incorporados em seu dia-a-dia. Beneficência e não-maleficência seriam os primeiros, os mais tradicionais, já com longa tradição no arsenal epistemológico bioético, muito antes do neologismo 'bioético' ser criado. Respeito à autonomia e justiça são "invenções" recentes. Particularmente o respeito à autonomia, já que era o paternalismo declarado que prevalecia nas relações entre o profissional da saúde e paciente e, por extensão, profissional de pesquisa e participante.

A simplicidade intuitiva de Principles of Biomedical Ethics, entretanto, não deve levar a crer que os autores não se apoiaram na tradição filosófica para construir seu arcabouço. Embora já fosse possível identificar a fonte em que beberam desde as primeiras edições, foi a partir da quarta edição (1994) que eles próprios decidiram nomeá-la - a moralidade comum. (1) Tratava-se de uma tentativa de resposta às críticas surgidas a partir do início da década de 1990, algumas das quais a serem analisadas aqui.

A moralidade comum de Beauchamp e Childress tem exatamente as características necessárias a um projeto que se pretende capilar e asséptico. Capilaridade conseguida pela simplicidade, e assepsia, pela aparente neutralidade. 'Moralidade', como os próprios autores lembram logo no início de Principles of 
Biomedical Ethics (2) é um termo amplo, que abarca regras de conduta aceitas de forma geral pelas pessoas. Os autores não o fazem, mas poderiam ter lançado mão da etimologia latina da palavra 'moral', que remete a 'costumes'. Será moralmente correto aquilo com que estamos acostumados. Como será discutido adiante, há um enorme problema com essa abordagem ética. Por ora, basta chamar a atenção para a grande conveniência dessa abordagem para a proposta de Beauchamp e Childress. Sendo seus princípios aquilo com que as pessoas estavam acostumadas, percebe-se como nem seria preciso adicionar a palavra 'comum' à moralidade.

Beauchamp e Childress, entretanto, precisavam reforçar essa característica pretensamente universalista de sua proposta, não abrindo mão, pois, do termo 'comum'. Seus princípios seriam 'comuns' a todos, aceitos por todos. Mas 'moralidade comum' não é um termo criado por eles, tem raízes na tradição filosófica, particularmente as propostas britânicas e americanas a partir do século XX. Uma dessas propostas, apesar de não utilizar o termo 'moralidade comum', é a que mais se aproxima da proposta de Beauchamp e Childress, justamente por sua natureza essencialmente intuitiva(1). Trata-se da proposta de W.D. Ross, um conhecido tradutor de Aristóteles para a língua inglesa. Sua principal obra de filosofia moral, Foundations of Ethics (1939), lança as bases de uma moral 'vulgar', a moral do vulgo, intuitiva.(3)

Além de Ross, Beauchamp e Childress ainda citam como fontes inspiradoras para sua moralidade comum, Alan Donagan (4) e Bernard Gert (5), além de integrantes de seu próprio grupo no Kennedy Institute of Ethics, da Universidade de Georgetown.

A fortuna crítica à proposta principialista é grande. De forma geral, as críticas de autores com origem em países ricos têm seu foco na fundamentação filosófica. Já os autores com sua origem em países em desenvolvimento, embora sem perder de vista as falhas filosóficas, têm seu foco na aplicação prática. Aos últimos incomoda mais a pretensa assepsia e neutralidade do Principialismo, enquanto aos primeiros, a simplicidade, interpretada como falta de consistência. Ambas perspectivas críticas são pertinentes e relevantes, e ambas serão analisadas aqui. Trata-se de responder a uma pergunta importante: a moralidade comum, como fundamentação ao Principialismo, é satisfatória? Existe mesmo tal coisa como uma 
'moralidade comum'?

O objetivo desse trabalho é avaliar criticamente a teoria da moralidade comum como fundamentação ao principialismo de Beauchamp e Childress. Para tanto, seguirá o seguinte caminho. Primeiramente, analisaremos as propostas de Bernard Gert, Alan Donagan e W.D.Ross, citados por Beauchamp e Childress como criadores de suas próprias teorias de moralidade comum. Em seguinda, apresentaremos as características da proposta principialista de Beauchamp e Childress. Então, passaremos às críticas à teoria da moralidade comum e ao Principialismo de Beauchamp e Childress. A partir destes três primeiros passos, lançamo-nos à tentativa de uma resposta para a questão se a moralidade comum é satisfatória. É o momento em que nos deparamos com outra questão fundamental, a saber, se existe de fato uma moralidade comum, já que há diferentes propostas, incluindo algumas que não se utilizam do termo 'moralidade comum', mas, na prática, equivalem a uma. Nas considerações finais, apresentamos nossa conclusão e ousamos arriscar uma proposta normativa própria. 


\section{TEORIAS ÉTICAS COM FUNDAMENTAÇÃO NA MORALIDADE COMUM}

\subsection{A TEORIA DA MORALIDADE COMUM DE BERNARD GERT}

O principialismo, tal como concebido por Beauchamp e Childress, tem lançado mão, de forma crescente, de uma teoria moral conhecida como 'moralidade comum'. Na última edição de seu Principles of Biomedial Ethics (2013), os autores dedicam vários capítulos para a justificação de sua abordagem à bioética a partir dos quatro princípios - respeito à autonomia, não-maleficência, beneficência e justiça. $O$ primeiro e o último capítulos são particularmente dedicados à apresentação e desenvolvimento da teoria da moralidade comum. Já no primeiro, os autores reconhecem que não são os únicos a se valer de tal teoria. Em uma nota, afirmam: "Embora haja apenas uma moralidade comum universal, há mais de uma teoria da moralidade comum"(6). Citando, em seguida, algumas delas. Entre as citadas, uma chama a atenção, por se tratar de um crítico do principialismo - Bernard Gert.

No último capítulo, Beauchamp e Childress tentam desenvolver melhor sua teoria da moralidade comum, quando, novamente, citam (desta vez mais detidamente) a de Gert (7). É digno de nota, entretanto, que os autores não discordem essencialmente de Gert, mas, apenas, das críticas deste ao principialismo:

Como nós, eles entendem a moralidade comum como moralidade universal,
que não é relativa a culturas, indivíduos, religiões ou associações
profissionais. Entretanto, Gert (e seus colaboradores) rejeitam tanto a
linguagem quanto a substância de nossa versão dos princípios, ao colocar
suas próprias regras imparciais e ideais morais como um sistema alternativo
superior para a ética biomédica.(8)

Mais adiante, os autores voltam à teoria da moralidade comum de Gert para concordar com ele na medida em que consideram não haver razão para que as normas da moralidade comum não possam ser justificadas por uma teoria ética geral, ainda que ele, Gert, não o tenha conseguido de forma conclusiva.(9)

Embora Beauchamp e Childress demonstrem crescente preocupação com a elaboração de uma teoria moral que dê sustentação a sua abordagem bioética, não o fizeram de forma aprofundada e sistemática como os demais autores que eles 
próprios citam, entre eles, Bernard Gert (5). O objetivo do presente artigo é apresentar a teoria da moralidade comum de Gert, a partir da obra de sua autoria Common Morality. Deciding What to Do.(5)

\subsubsection{Características Gerais}

De acordo com Bernard Gert, moralidade comum é o sistema moral que as pessoas usam implicitamente quando tomam decisões e fazem julgamentos. Por "as pessoas" entenda-se a humanidade toda. Ou quase toda. Excetuam-se aqueles que, pela idade ou estado mental incapacitante, não possam ser considerados agentes morais (ainda que continuem sendo recipientes morais). Já temos aqui então a primeira característica nuclear da moralidade comum - seu apelo a uma natureza humana universal.(10)

Sendo próprio da natureza humana a razão, sê-lo-á igualmente que esta seja um pré-requisito da aplicação correta da moralidade comum. Todo ser humano racional se valerá dela para tomar suas decisões. O que não significa dizer, de acordo com Gert, que concordarão sempre(10). A moralidade comum permite discordâncias, e até mesmo que estas sejam igualmente legítimas. Temos, então, a segunda característica nuclear: a moralidade comum não é rígida. Embora uma tal característica seja óbvia, já que a nenhum autor ocorreria propor um sistema de normas morais fechado, está aqui um dos principais problemas da teoria de Gert, como pretendemos mostrar adiante.

A existência de uma moralidade comum, ou DA moralidade comum, como quer Gert (e Beauchamp e Childress) é quase intuitiva. Vem da constatação de que todas as pessoas concordam tacitamente em se comportar em relação uns aos outros a partir de regras não escritas, mas aceitas por todos (10). Por exemplo, todos concordam que matar, causar dor ou incapacidade, ou ainda retirar a liberdade ou prazer de qualquer outro agente moral será imoral, a não ser que haja uma justificativa adequada para tal ação (11). Da mesma forma, todos os agentes morais concordam que ações tais como salvar vidas, aliviar ou prevenir dor, curar ou prevenir incapacidades, e impedir a perda de liberdade ou prazer são ações moralmente boas, a não ser que ao fazê-las viole-se uma regra moral.(11) 
Outra característica importante e que também diz respeito à natureza humana é o reconhecimento de nossa falibilidade e fragilidade, o que forçosamente (se seguirmos Gert) nos faz obedecer ao que manda a moralidade comum, pois não queremos sofrer dano de qualquer espécie, portanto desejamos que todos observem as regras tacitamente aceitas para isso. Interessante notar que uma outra abordagem à ética diferente (a partir das virtudes, do filósofo Alasdair Maclntyre) também tem esse ponto de partida (12). E assim como se pode questionar a Maclntyre por que a constatação de qualquer característica humana tem como consequência a observância de uma determinada norma moral, assim também a Gert.(13)

A moralidade comum teria ainda, de acordo com Gert, quatro pontos principais de potencial discordância. O primeiro seria quem merece a consideração da moralidade comum. Fetos, por exemplo, estão completamente cobertos pela proteção das regras da moralidade comum? O segundo ponto seria acerca da diferente gradação para os diferentes danos que cada um pode dar. O que seria pior, morte ou coma permanente? (Para citar um caso extremo). O terceiro ponto de potencial discordância seria o fato das pessoas poderem estimar diferentemente as consequências danosas de um determinado ato. Por último, as diferentes possibilidades de interpretação de uma determinada regra moral.(14)

Como uma grande gramática, acredita Gert, a moralidade comum provê um sistema universal para todos os códigos morais particulares.(15)

\subsubsection{O Sistema Moral de Bernard Gert}

O sistema moral no qual está contida a moralidade comum compõe-se, basicamente, de regras morais, ideais morais e um procedimento de dois passos usado intuitivamente por todas as pessoas para decidir se uma determinada violação de uma regra ou ideal é legítima (16). Tal procedimento será detalhado brevemente.

Faz parte do sistema da moralidade comum que haja espaço para discordâncias. Ou seja, embora se componha de regras universais, estas não necessariamente serão sempre universalmente aceitas e acatadas. E quais seriam estas regras? 
1- Não mate

2- Não cause dor

3- Não incapacite

4- Não prive da liberdade

5- Não prive do prazer
6- Não engane

7- Mantenha suas promessas

8- Não trapaceie

9- Obedeça a lei

10- Faça seu dever

Propositadamente, mantivemos aqui a configuração escolhida por Gert em seu livro, que foi deliberada. O motivo é que divide as dez regras em duas metades, podendo a primeira ser reduzida a uma - Não cause dano - e a segunda a outra Não viole a confiança.(17)

Também deliberada foi a escolha do número de regras - dez. A justificativa, entretanto, é pouco convincente:

Tendo dez regras morais, como esta formulação tem, vale-se de uma tradição bem conhecida. Que apresentando exatamente dez regras leva alguns filósofos a tentarem mais intensamente encontrar falhas como um "bônus" não pretendido. Esta formulação também resulta nas regras sendo divididas de forma bacana em duas categorias distintas, sendo as cinco primeiras as que proíbem diretamente causar todo tipo básico de dano, e as segundas proibindo as ações que indiretamente causam esse tipo de dano.(18)

Os ideais morais não são especificados por Gert, por considerá-los óbvios. Por outro lado, sua força seria inferior à das regras morais, o que significa dizer que, ao contrário das regras, as pessoas não são obrigadas a seguir os ideais morais. Não causar dor, uma regra moral, torna-se, em linguagem mais fraca, portanto de ideal moral, prevenir que alguém sinta dor. A primeira seria uma obrigação, a segunda, não. A não ser que faça parte dos deveres do agente moral, por exemplo, um médico. Se este não prevenir dor estará quebrando a regra moral "faça seu dever".(19)

Neste ponto vale interromper a descrição do sistema moral de Gert para discutir algumas críticas pertinentes. A primeira vem de Beauchamp e Childress. Ao 
rebaterem as críticas que Gert faz ao principialismo, os autores citam o problema da subestimação dos ideais morais perante as regras morais. Gert erra, acreditam eles, ao colocar o princípio da beneficência como "apenas" um ideal, portanto "abaixo" de uma regra, portanto não obrigatório. Tal erro não seria apenas um erro de julgamento (beneficência como não merecedora do status de regra moral), mas também uma incoerência do sistema de Gert. Afinal, no que diz respeito à ética biomédica, fazer o bem sempre cairá na categoria de fazer seu dever, pois se trata de profissionais da saúde.(20)

Uma crítica mais contundente, embora não seja dirigida especificamente a Gert, diz-Ihe respeito na medida em que trata do papel dos ideais morais. Trata-se da proposta de uma mudança radical de perspectiva, com origem na Bioética Latinoamericana - a Bioética de Intervenção (21). Por tal perspectiva, responsabilidade, cuidado, solidariedade, comprometimento, alteridade, tolerância, prevenção de danos, precaução frente ao desconhecido, prudência com relação aos avanços e novidades e proteção dos excluídos sociais, doa mais frágeis e desassistidos (22), uma lista que Gert classificaria como de ideais morais (com a exceção de prevenção de danos), portanto não obrigatórios, tornam-se imperativos categóricos.

\subsubsection{As Regras Morais}

Não mate. Deve ser interpretada como "não cause perda permanente da consciência", pois, a não ser que alguém tenha algum tipo de crença religiosa que endosse a ideia de que mesmo sem consciência (permanentemente) o ser humano está vivo, a regra "não mate" se aplica a casos em que o dano sofrido não resultou em morte. Mas não é o mesmo que causar perda de consciência temporariamente, que se encaixaria na regra moral "não incapacite".(23)

Não cause dor. De maneira geral, toda pessoa racional deseja não ter dor, embora haja casos em que em que, mesmo mantendo sua racionalidade, pode desejar sentir dor (sentimento desagradável). Por exemplo, passear em montanha russa ou ver filme de terror.(24)

Não provoque incapacidade. Cegar uma pessoa, arrancar-lhe um braço seriam exemplos claros de quebra desta regra moral. Mas não estariam incluídas 
apenas as possibilidades de incapacidade física, como também mental e, mesmo, volitiva. Por exemplo, fornecer à pessoa algumas drogas, lícitas ou não.(25)

Não prive da liberdade. Neste caso não estariam incluídas as perdas de liberdade por incapacidade (por exemplo, se alguém provoca que outrem perca os membros inferiores, este terá sua liberdade de movimento bastante comprometida, mas, nesse caso, estaremos diante da quebra da regra moral "não provoque incapacidade", ou ainda "não cause dor"). Coerção pode ser considerada como uma quebra desta regra. Discriminação também (por exemplo, na seleção para um emprego).(26)

Não prive do prazer. Parar de coçar as costas de alguém não, mas tomar o sorvete de alguém sim, caracteriza-se como uma quebra desta regra.(27)

Não engane. Esta redação, acredita Gert, é mais adequada do que a mais comum "não minta" porque pretendendo enganar contando uma mentira é apenas uma forma de enganar. E mesmo que a pessoa não esteja certa de que está enganando (por exemplo, quando ajuda a espalhar um boato), está quebrando esta regra moral.(28)

Mantenha suas promessas. Trata-se da primeira das dez regras que não é formulada como uma negação, uma proibição. Mas poderia: "Não quebre suas promessas". Está assim para que se pressuponha que algo já foi prometido, e não deve ser desrespeitado.(29)

Não trapaceie. Não deve, de acordo com Gert, ser vista apenas como outra forma de dizer "não minta" ou "não engane" ou "mantenha sua promessa". Pois trapacear nem sempre envolve enganar, por exemplo, "no caso de um chefe trapacear num jogo de golfe e seus subordinados não falam nada".(30)

Obedeça a lei. Ainda que se considere que possa haver leis injustas (leis discriminatórias, por exemplo), a maioria será boa e justa, e obedecê-las é visto por todos como moralmente louvável. A diferença entre um sistema moral e o legal é que do primeiro não se espera que se resolva todos os casos, enquanto do segundo, sim. Um sistema moral não tem a obrigação de dar uma resposta definitiva e unânime. Um sistema legal, por mais que a decisão seja ruim, tem o dever de 
fornecer a resposta final a um dilema.(31)

Faça seu dever. Enquadram-se aqui tanto os casos das pessoas com dever profissional (médico, advogado, professor, etc), como familiar (pais) e também circunstancial. Neste último caso, entretanto, Gert faz uma diferenciação. Se alguém está circunstancialmente em posição de ajudar outrem (salvar de afogamento, por exemplo), é obrigado apenas se a situação lhe trouxer risco insignificante. Em qualquer outra situação, não será regra moral, mas apenas ideal moral (louvável, mas não obrigatório).(32)

\subsubsection{A Quem se Aplicam as Regras Morais?}

As regras morais se aplicam aos agentes morais, que serão todos e apenas aqueles seres humanos capazes de compreender completamente as regras morais, assim como prever as consequências de sua eventual quebra. Do que se depreende que animais não humanos, crianças e pessoas com problemas mentais incapacitantes não podem ser agentes morais. Mas do que não se deve depreender, entretanto, que não tenham direito à proteção conferida pelas regras morais. Ser um agente moral implica ser totalmente responsabilizável pelos próprios atos. Um agente moral pode ser julgado moralmente. Não faz sentido julgar moralmente um não agente moral (33). Posto dessa forma, parece clara a fronteira entre aqueles que estão abarcados pela proteção conferida pelas regras morais e aqueles que não estão. Mas certamente não é o caso. O feto, por exemplo, a partir de quando "merece" a consideração das regras morais? E os animais? Nenhum? Somente os mais próximos ao homem? Somente os mais inteligentes? Tais questões são dilemas persistentes da ética e que o sistema moral de Gert não pretende resolver. O que não chega a ser problemático, até pelo contrário, é honesto que o reconheça.

O problema começa quando, ainda tentando resolver a questão de a quem se aplica seu sistema de moralidade comum, Gert se perde num labirinto sem saída possível, muito parecido, por sinal, com o caso de Beauchamp e Childress. Estes, para justificar sua teoria da moralidade comum experimentalmente, propõem uma saída questionável. Para provar que a moralidade comum existe, de acordo com eles, seria necessário fazer um desenho de experimento cuja amostragem se 
compusesse de pessoas que, de saída, aceitassem a premissa de que os princípios são sua base de julgamento moral (senão todos, pelo menos a não-maleficência) (34). Caricaturando, é quase como se alguém quisesse testar a hipótese de que todos gostam de sorvete de morango colhendo, como amostra, apenas pessoas que dizem gostar sorvete de morango. Um enorme viés de seleção.

Gert faz algo semelhante. Para ser um agente moral, este não só tem de ter um mínimo de inteligência e maturidade para compreender as regras da moralidade comum, assim como ter a capacidade de prever as consequências de sua quebra, mas também deve ser munido de certas crenças - as crenças requeridas de todos os agentes morais. Quais seriam? Por exemplo, o reconhecimento da fragilidade e falibilidade do ser humano. Ainda, o que desejam as pessoas racionais, que as pessoas racionais não desejam ser mortas, ter dor, sofrer incapacidade, ter a liberdade retirada, ser enganada ou trapaceada, enfim, o agente moral no sistema da moralidade comum é aquele que, de saída, aceita as premissas da proposta de uma moralidade comum. Um argumento circular que não responde, nem à pergunta se existe de fato uma moralidade comum, nem quem se habilita como agente moral.

A crítica mais óbvia aqui será a de Carson Strong:

\begin{abstract}
Em outras palavras, temos de imaginar a hipotética situação na qual todas as pessoas plenamente informadas, racionais e imparciais devem estimar as consequências. É claro que várias pessoas racionais [que, mesmo se encaixando nessa caracterização] não têm o conhecimento da cultura norteamericana. Portanto, podem não estimar as consequências que seriam tidas como permitidas pelo público norte-americano.(35)
\end{abstract}

Strong se refere a avaliação das consequências de um ato para caracterizá-lo como quebra admissível ou não de uma regra moral, algo que será analisado a seguir, mas sua ponderação acerca das diferenças culturais vale também para o sistema moral como um todo.

\title{
2.1.3.3 Violando as Regras Justificadamente
}

É claro, e Gert não pretende negar, que todas e cada uma das regras morais podem ser violadas sem, necessariamente, que se esteja sendo imoral ao fazê-lo. Quais serão as justificativas aceitáveis? 
Em primeiro lugar, Gert enfatiza a importância que a racionalidade tem para sua teoria moral. Racional será tudo aquilo que não for irracional. Define-se, então, primeiro, o que seja irracional, o que sobrar será racional. Será objetivamente irracional (irracional independente de um julgamento individual, subjetivo), o ato intencional de causar (ou aumentar o risco de causar) morte, dor, incapacidade, etc, sem que haja uma razão objetiva adequada para tal ação (36). E será razão objetiva adequada qualquer razão que for considerada como tal por um grupo significativo de pessoas. Gert é explícito quanto a esse detalhe quantitativo de sua teoria:

Se somente uma pessoa advoga aos que lhe importam que eles devem
fazer algumas ações que provoquem danos a elas mesmas, esta pessoa
não será considerada uma pessoa racional. Se somente um número
pequeno de pessoas defender ações que provoquem danos nelas mesmas
às pessoas que Ihes importam pelas razões que apresentar, este pequeno
número de pessoas também não será considerado racional. Entretanto,
qualquer razão que qualquer número significativo de pessoas racionais
determinar que é adequada, será objetivamente adequada.(37)

Interessante notar que a leitura deste trecho remete imediatamente a exemplos históricos de ações profundamente imorais que foram endossadas por um número significativo de pessoas, como o caso do Estudo de Tuekegee(38) e, claro, do nazismo. Foi a partir do nazismo, mais especificamente da análise do "Caso Eichman", que Hannah Arendt fez uma observação acertada e pertinente também aqui:

A moralidade desmoronou e transformou-se num mero conjunto de costumes - maneiras, usos, convenções a serem trocados à vontade - não entre os criminosos, mas entre as pessoas comuns, desde que os padrões morais fossem socialmente aceitos [...].(39)

Gert também faz referência ao nazismo, porém por outra perspectiva. Não propriamente ao nazismo, mas ao nacionalismo, para exemplificar que não necessariamente os piores atos morais vêm do egoísmo, mas, sim, de ações justificadas por racismo, religião e nacionalismo. Tais ações seriam, sim, racionalmente permitidas. Estamos aqui diante de um paradoxo. Gert está sendo coerente quando considera tais situações como "racionais", afinal, são endossadas "por um número significativo de pessoas". No entanto, são ações indubitavelmente erradas moralmente. Como pode ser?

A saída arquitetada por Gert é o teste da imparcialidade. Não basta ser racional, nem mesmo objetivamente racional (como vimos), é preciso ser imparcial: 
A maneira como uma pessoa demonstra sua imparcialidade é violando uma regra apenas se ela puder desejar que todos possam violar essa mesma regra, dadas as mesmas circunstâncias. Ela estaria disposta a permitir que todas as pessoas soubessem de sua violação apenas se estimasse que melhores consequências resultariam se todos soubessem do que se todos soubessem que [eles próprios] não teriam permissão de violar a regra em tais circunstâncias.(40)

Chama a atenção a semelhança com o imperativo categórico kantiano "Age de tal modo que a máxima da tua vontade possa valer sempre e ao mesmo tempo como princípio de uma legislação universal" (41). Mas não exatamente, pois Gert é explícito com relação às consequências do ato. Que uma condição universalizante seja aplicada a uma proposta moral também universalizante, como a moralidade comum, não é propriamente uma surpresa. Trata-se, de certa maneira, de uma inversão da estória do anel de Giges, narrada por Glauco no Livro II d'A República de Platão(42), usada para demonstrar que as pessoas só agirão de forma ética se forem flagradas.

À primeira vista, faz sentido. Se não me importo que todos saibam, então é porque minha violação da regra é justificada. Basta uma reflexão mais atenta, entretanto, para se descobrir as várias possibilidades de falha desse critério. Em primeiro lugar, quem são todos? Já sabemos, e o próprio Gert se dá conta, que não tem como ser todos no sentido literal. Ele lembra, oportunamente, que nunca se é simples e isoladamente imparcial, mas, sim, é-se imparcial em relação a algo ou alguém. Não existe "imparcialidade universal". Em segundo lugar, sempre há a possibilidade de se ter alguém que seja racional e, mesmo assim, não se importe que todos tomem conhecimento de seus malfeitos, por se encontrarem em posição privilegiada, como, recorrendo novamente a Platão, vimos Trasímaco, no Livro I d'A República de Platão (43) ponderar e o próprio Gert reconhecer.(44)

Outro problema, também reconhecido por Gert, é o da diferença na atribuição de um valor para os males e danos causados por determinada violação de regra, assim como na estimativa dos possíveis danos. Alguém pode quebrar uma regra, por exemplo, não causar dor, prevendo que a consequência desta violação será menos pior do que obedecê-la. O que nos traz de volta à crítica de Carson Strong, citada anteriormente. Este se vale de alguns casos para demonstrar como a teoria da moralidade comum de Gert é falha quando aplicada à ética biomédica. Na avaliação de Gert, por exemplo, se um fisioterapeuta forçar um paciente a levar a 
cabo todas as sessões de reabilitação pós-derrame, estará errado por violar a regra de "não causar dor", ao assumir tal atitude paternalista. Na opinião de Strong, essa atitude pode ser considerada eticamente justificável, entre outros motivos, por estar o paciente com sua autonomia prejudicada, e, se não for estimulado (até forçado) a terminar o tratamento poderá sofrer maior dano do que se lhe for permitida a interrupção.(45)

Beauchamp e Childress fazem crítica semelhante, exemplificando com um caso de um paciente que, após um acidente, quando ainda consciente, manifesta desejo de não ser submetido à transfusão de sangue. Em seguida perde a consciência. Suas chances de manter a vida são pequenas, mas maiores, se for submetido à transfusão. Se o médico fizer estará quebrando a regra "não causar dor" (neste caso psicológica) da moralidade comum de Gert. O médico faz, salvando a vida do paciente. E aí há duas possibilidades: se o médico contar que fez causará a dor psicológica no paciente; se não contar, o estará enganando. Mas, se o paciente morrer de toda forma, o médico nada fez de errado, a seguir o raciocínio de Gert, pois não terá nem causado dor, nem enganado o paciente. Uma situação problemática, de acordo com Beauchamp e Childress, para os quais o médico terá violado o princípio do respeito à autonomia, independente do paciente morrer ou viver.(46)

\subsection{A TEORIA MORAL DE ALAN DONAGAN}

Na última edição de seu Principles of Biomedical Ethics, citam a teoria moral de Alan Donagan (6) como uma das propostas teóricas de moralidade comum. Esta será apresentada a seguir.

\subsubsection{Uma teoria moral é uma teoria de quê?}

A abordagem de Alan Donagan é, diferentemente da de Beauchamp \& Childress (4) (1) e de Bernard Gert (5), sistemática. Donagan começa procurando clarear o terreno para galgá-lo aos poucos. Pergunta-se: Uma teoria moral (ou, como ele prefere, teoria da moralidade) será uma teoria exatamente do quê? Uma primeira resposta possível seria dada pela tradição judaico-cristã: é a teoria de um sistema de 
leis ou preceitos que ligam todas as criaturas racionais, cujo conteúdo é averiguável pela razão humana.(47)

Começando pelos estoicos e seguindo com os judeus e cristãos, a ideia de que uma lei divina válida para todos a partir da característica comum que é sua racionalidade, é a base para a moralidade comum. O fato de ser 'divina', no entanto, não deve levar a pensar que se trata de uma moral necessariamente religiosa. Pois há um pressuposto - a razão humana. Trata-se de um código universal que, embora endossado por Deus (ou pelos deuses), não necessita que se acredite n'Ele para ter acesso ao código. Tal acesso é garantido pela razão (48). Uma tal lei será, portanto, natural.

\subsubsection{A lei Natural de Tomás de Aquino}

Alan Donagan não se vale da teoria das virtudes aristotélico-tomista, pelo contrário, critica a teoria ética de Aristóteles, que teria antecipado os estoicos se tivesse desenhado suas virtudes como de caráter universal (49). Por outro lado, a concepção tomista da Lei Natural tem importância chave em sua teoria moral.

Em sua obra Suma Teológica, estruturada em perguntas, a pergunta de número 94 trata da Lei Natural em seis artigos (50). O primeiro artigo pretende responder à pergunta - O que é a Lei natural? A Lei Natural é um hábito, no sentido de, ao mesmo tempo, ser algo inato e cultivado pelo hábito da razão prática. Como sindéresis, será a lei de nossa mente, um hábito contendo os preceitos da Lei Natural, que são os primeiros princípios das ações humanas.(51)

O Segundo artigo responde à pergunta: Quais são os preceitos da lei natural? Mas primeiro é preciso decidir: há apenas um preceito ou há vários? Se vários, então várias serão as leis naturais. Não é o caso. Há um princípio fundamental fazer o bem e evitar o mal - a partir do qual todos os preceitos derivam. Há vários preceitos, mas uma raiz comum, portanto apenas uma Lei Natural.(52)

O Terceiro artigo trata das virtudes. Serão elas prescritas pela Lei Natural? Sim, se considerarmos as virtudes em termos gerais. Sendo as virtudes uma consequência natural da deliberação racional de seres racionais, estas serão 
prescritas pela Lei natural. Por outro lado, se considerarmos os atos virtuosos propriamente ditos, considerados em sua particularidade, nem sempre serão consequência de uma inclinação natural, portanto não prescritos pela Lei natural.(53)

Quarto artigo: Será a lei natural a mesma para todos os homens? Neste ponto Thomás de Aquino nos faz lembrar das ponderações de Beauchamp \& Childress acerca das especificações de normas abstratas e regras, que permitem, ao mesmo tempo, uma aplicabilidade de tais normas (por sua vez derivadas da moralidade comum), mas também a possibilidade de um distanciamento destas a ponto de as distorcer. Para Beauchamp \& Childress, a especificação progressiva pode acontecer, desde que mantenha uma conexão com a norma geral que a originou (54). Tomás de Aquino propõe uma solução diferente, mais realista. O princípio geral - a Lei Natural - seria o mesmo, mas, à medida que a razão prática descesse a detalhes, enroscando-se em contingências, poderiam aparecer conflitos. Por exemplo, devolver a outrem o que lhe é de direito seria um princípio geral que poderia não valer em casos específicos, como por exemplo, se a devolução resultará em prejuízo numa guerra contra o país de quem está devolvendo. Tomás de Aquino acrescenta, então, a condição "maioria". Um princípio geral caberia na maioria dos casos, mas exceções seriam possíveis. A Lei Natural teria um princípio fundamental e vários princípios gerais dele originados, sempre como consequência de uma deliberação racional a que estamos naturalmente inclinados. Tais princípios não estariam imunes à contingência.(55)

A Lei Natural pode ser mudada? Com o artigo quinto, Tomás de Aquino apresenta mais uma característica da Lei natural, a saber, sua imutabilidade quanto aos princípios fundamentais, mas mutabilidade quanto aos derivados. Pode ser tanto por adição quanto por subtração. O processo de adição nada mais seria do que as especificações ditadas pelas circunstâncias mencionadas no quarto artigo. $O$ de subtração poderia acontecer em relação aos princípios derivados, mas não nos fundamentais. Uma especificação motivada por uma contingência pode mudar, retirando a validade de um princípio secundário. Nesse ponto cabe citar, ainda que se leve em consideração a época em que foi escrita a obra, que o processo de adição justificaria a posse de coisas e mesmo pessoas (escravos).(56) 
Por fim, o artigo sexto questiona se a Lei Natural pode ser abolida do coração humano. Os princípios gerais não têm como ser apagados do coração humano, mas não estão imunes à não utilização em caso de concupiscência ou alguma outra paixão contaminando a razão prática do indivíduo. Os princípios secundários podem ser abolidos do coração humano por meio de hábitos corruptos ou costumes viciosos.(57)

Voltando a Donagan, este acredita que a contribuição do judaísmo e do cristianismo para a construção de uma teoria moral é sua concepção comum do que vem a ser uma teoria moral: é uma teoria de um sistema de leis e preceitos que interliga criaturas racionais como tais, cujo conteúdo é acessível pela razão humana (47). Mas tal contribuição não seria completamente satisfatória se não tivesse sido traduzida fora do terreno da teologia e dentro da filosofia. Tal tarefa coube a Kant.

Sendo a moralidade comum um sistema de preceitos sobre as ações humanas, a forma mais comum de sua expressão será a proibição. As ações que forem contrárias à razão não serão permitidas (58). Assim, um 'preceito' será toda e qualquer proposição universal da moralidade comum que diga respeito à permissibilidade de uma ação (59). Por serem anteriores a qualquer julgamento de culpabilidade, questões morais de permissibilidade serão "de primeira ordem", enquanto de culpabilidade, "de segunda ordem", seguindo, assim, a tradição judaicocristã.(60)

\subsubsection{O Princípio Fundamental}

Também seguindo a tradição judaico-cristã, o princípio fundamental terá sua origem no Talmud, a partir de um dizer de Hillel: "Não faça a seu próximo o que não gostaria que fosse feito a você". Ou na Bíblia, pela boca de Jesus: "Tudo o que quiser que os homens façam a você, faça você a eles". Embora uma seja negativa e outra, positiva, as duas dizem a mesma coisa, que ficou conhecida como "a Regra de Ouro" (61). Donagan reconhece algumas objeções à Regra de Ouro. A primeira e mais óbvia, que não será necessariamente condenável que se faça a outrem algo que não se gostaria fosse feito a nós. Um juiz condenará à cadeia um assassino e certamente tal juiz não gostaria de ir, ele próprio, para a cadeia. A segunda é menos óbvia, mas é cara a Donagan. A Regra de Ouro não prevê a condenação moral de 
qualquer ação que prejudique apenas quem a pratica, sendo um exemplo clássico, o suicídio.(62)

Mas a principal crítica à adequação da Regra de Ouro como princípio fundamental é posta pelo próprio Donagan. O que alguém considera aceitável fazer a outrem estará diretamente relacionado aos costumes da comunidade em que vive, portanto, mau candidato a uma formulação que se pretenda universal. Nesse sentido, o primeiro imperativo categórico kantiano carrega ônus semelhante: "Age de tal forma que tua ação possa se transformar, por tua vontade, em lei universal”. Ao aplicar sua ação ao crivo de seu julgamento se pode se transformar em "lei universal", o sujeito da ação estará contaminado pelos costumes de sua comunidade.(63)

É necessário, portanto, buscar outro candidato a princípio fundamental dentro da tradição judaico-cristã e, a partir deste, um correspondente na tradição filosófica. Tal será o caso da parábola do Bom Samaritano, no Evangelho de Lucas: "Tu deverás amar o Senhor teu Deus com todo teu coração, e toda tua força e toda sua mente; e deverás amar teu vizinho como a ti próprio". Também aqui cabe uma ponderação crítica. O mesmo ensinamento está presente em Leviticus, e nesse caso "vizinho" é tomado em sentido mais estrito (seu vizinho judeu), enquanto no Evangelho de Lucas, mais amplo (vizinho como "o outro", qualquer outro).(64)

Thomas de Aquino, lembra Donagan, considerou tal princípio como principium communissimum. E Kant, acredita Donagan, o formulou filosoficamente em seu segundo imperativo categórico: "Age de tal maneira que uses a humanidade, tanto na tua pessoa como na pessoa de qualquer outro, sempre e simultaneamente como fim e nunca simplesmente como meio" (65). Donagan, por sua vez, propõe a seguinte formulação: Aja sempre de tal forma que você respeite cada ser humano, seja você mesmo ou outro, como sendo uma criatura racional. Temos aí o princípio fundamental da moralidade comum de Alan Donagan.(66)

\subsubsection{A Classificação dos Preceitos de Primeira Ordem}

Os preceitos de primeira ordem dizem respeito ao que é permitido. Donagan divide tais preceitos, tendo como ponto de partida o princípio fundamental da 
moralidade comum, em três: 1- Deveres de cada ser humano para consigo mesmo; 2- Deveres de cada ser humano para outros seres humanos e 3- Deveres surgidos com a participação em instituições humanas.(67)

1- Deveres de cada ser humano para consigo mesmo. Aqui Donagan segue Kant e sua Metafísica dos Costumes (68), para quem tirar simplesmente a própria vida fere centralmente seu segundo imperativo categórico. Admitindo-se o suicídio como o pior dano físico que um ser humano pode fazer contra si, o preceito de primeira ordem da moralidade comum seria: Não é permitido para nenhum ser humano tirar sua própria vida por mero querer (69). Tal preceito admite exceções. Por exemplo, no caso em que o sacrifício de alguns é mandatório para que muitos sobrevivam. Ou ainda em casos em que alguém terá sua vida desumanizada antes de sua morte. Donagan aproveita o exemplo de Kant, de alguém com hidrofobia. $O$ que leva a pensar em casos mais contemporâneos (não citados por Donagan), como demência por doenças neurodegenerativas.

O primeiro preceito deve ser ainda estendido para planejamento de vida. Não apenas não é permissível que alguém cometa dano contra si, como também não é permissível que alguém não planeje que seu potencial físico e mental seja desenvolvido.(70)

2- Deveres não institucionais a outros seres humanos. Este preceito de primeira ordem seria formulado da seguinte maneira: não é permissível para ninguém usar força sobre outrem sem uma justificativa aceitável. Autodefesa é uma exceção legítima que vem logo à mente. Assim como usar de violência contra alguém que ameaça outrem.

Tal preceito não se aplica somente a seres humanos adultos e autônomos, mas a qualquer ser humano. O que leva à pergunta: e quando começamos a ser humanos? De acordo com Donagan, já a partir da concepção. Não faz sentido e chega a ser desonesto considerar um ser humano apenas quando pode viver fora da barriga da mãe, pois isso está na dependência direta da tecnologia médica disponível no momento. Não é descabido que no futuro um zigoto seja viável.(71)

Desse preceito também derivará a proibição à escravidão. Derivará ainda o que Donagan chama de "Princípio da Beneficência": Não é permissível não 
promover o bem-estar de outros por ações, elas próprias permissíveis, desde que se o faça sem inconveniência proporcional. Os detalhes das ações elas próprias permissíveis é importante, pois, se para promover o bem-estar de outros eu tiver causar dano a alguém, isso não será beneficência. Por exemplo, se eu matar alguém e com a herança eu construir um hospital filantrópico.(72)

Também seguirá deste preceito a proibição para mentir. Donagan, entretanto, opta por uma formulação que, acredita ele, evita os questionamentos usualmente postos a Kant (73): não é permissível para ninguém, ainda que para um bom fim, em condições de comunicação livre, entre pessoas responsáveis, expressar uma opinião que não tem(69). Dizer a verdade a um assassino que pergunta onde está a pessoa que você está escondendo justamente dele, não se enquadra nesse preceito. Abre-se, assim, uma janela para uma mentira legítima. Entretanto, persistem várias outras situações em que mentir pode não ser apenas permissível, como moralmente desejável, ou até mesmo mandatório, para as quais, nem Kant, nem Donagan têm uma saída.

3- Deveres surgidos com a participação em instituições humanas.

Donagan divide o que ele chama de deveres institucionais em contratos, propriedade, família e sociedade civil.

Contratos. São os contratos, de acordo com Donagan, a instituição humana mais elementar. Por contrato ele entende as promessas. Portanto não (necessariamente) contratos escritos. A formulação ficaria assim: Não é permissível a ninguém quebrar uma promessa livremente acordada para fazer algo que seja moralmente permissível (74). Posta dessa forma, a promessa, acredita Donagan, evita algumas armadilhas possíveis como dever moral, a saber, a promessa de fazer algo moralmente condenável (prometer matar alguém por vingança, por exemplo). Escapa ainda da armadilha de ser obrigado a cumprir uma promessa forçada, por exemplo, no caso de ser solto por sequestradores e prometer pagar o resgate. Não evita, porém, a situação de se ter de quebrar uma promessa por um dever maior. Por exemplo, não comparecer a um encontro por ter tido de ajudar vítimas de um acidente. Este não chega a ser um problema, acredita Donagan, por causa de sua obviedade. Não se espera que alguém mantenha uma promessa se confrontado 
com algo moralmente mais importante.(74)

Propriedade. Seguindo a tradição judaico-cristã, a segunda instituição moral, como Donagan a chama, seria o dever moral de respeito à propriedade. Entretanto, não se trata de um dever (e/ou direito) moral absoluto, podendo haver, assim como no caso da promessa, exceções, quando colidirem com "moralmente permissível". Outra ressalva é que o termo propriedade não deve ser associado automaticamente com "propriedade privada", lembrando que há, naturalmente, propriedade pública. Esta seria o caso de ser uma propriedade (tangível ou não) de uma coletividade, enquanto aquela, de um indivíduo ou grupo de indivíduos. Faz parte do dever moral de respeito à propriedade não apenas o presente, mas o futuro. Ou seja, qualquer que seja o "dono" (coletividade ou indivíduo), este não pode dispor sem limites de sua propriedade, em detrimento das gerações futuras, particularmente no que diga respeito a recursos naturais. Os limites e regras de estabelecimento de propriedade pública ou privada serão determinados pelo tipo de sociedade em questão, mas será parte da moralidade comum não ser permissível roubar, seja com ou sem violência.(75)

Família. A primeira formulação para o dever moral relacionado à família diz respeito a tema sem muita controvérsia, ficando, por isso, fácil: Não será permissível ter filhos voluntariamente quem não tiver como mantê-los (76). O mesmo não pode ser dito, entretanto, no que diga respeito à manutenção de um casamento, assim como ao tipo de família. Buscando a resposta na tradição judaico-cristã, Donagan reconhece não haver consenso, por exemplo, quanto à obrigação de se manter um casamento ou ser legítimo um divórcio. Católicos romanos, por exemplo, diferem de outros cristãos, adotando uma postura mais conservadora. Reconhece ainda que um outro possível critério, a saber, a possibilidade de maior sofrimento aos membros da família (não só o casal, mas também os filhos), novamente não haverá consenso. Isso força Donagan a adotar como permissível à moralidade comum tanto uma coisa como outra (é permissível manter um casamento a despeito de não estar funcionando, assim como é permissível o divórcio em tal situação). Quanto à prática sexual em si, Donagan repele a abordagem tanto da tradição judaico-cristã, quanto de filósofos caros a ele, como Tomás de Aquino e Kant. Para Donagan, será moralmente permissível o ato sexual que não for física ou psicologicamente danoso 
a qualquer dos participantes de tal ato, ou que não seja degradante e explorador. Sado-masoquismo, prostituição e algumas formas de "sexo casual" seriam, portanto, não permissíveis. Homossexualismo seria moralmente permissível. Traição não seria não permissível pelo ato em si, mas pelo fato de ter havido uma "quebra de contrato".(77)

Sociedade civil. Desde que nem o sistema político, nem as regras de propriedade violem seriamente direitos morais, não será permissível aos integrantes de uma dada sociedade civil que desobedeçam a suas leis. Tal será a formulação a partir da moralidade comum, de acordo com Alan Donagan (78). Nota-se logo um problema, a saber, em que medida se considera direitos morais "seriamente violados"? Em que ponto se traça a linha que não pode ser ultrapassada? Admitindo-se que haja resposta satisfatória (em uma situação específica), chega-se inescapavelmente a outro problema: O que fazer nesse caso? Rebelião será permissível nesse caso, responde Donagan, desde que (e aqui outro problema praticamente insolúvel) saiba-se previamente se tal rebelião não corre o risco de causar mais mal do que bem, mais dano moral do que o aceitável. Quanto a servir numa guerra, será permissível, desde que a guerra seja "justa”. Se não for, será permissível recusar-se a servir.(79)

\subsubsection{Os Preceitos de Segunda Ordem}

Serão aqueles relativos a julgamentos morais. Para que um ato humano seja passível de elogio ou condenação, a primeira coisa a fazer é esclarecer o que se entende por "ato" e se há diferença entre esse termo e "ação". Donagan se vale de uma ilustração para distingui-los: Se alguém tosse de propósito para atrair atenção, isso será uma ação, pois se trata de ato voluntário. Se tosse como reação corporal, será ato não voluntário. Se tosse como consequência de uma reação incontrolável a uma irritação na garganta, será ato involuntário (80). Outra distinção importante diz respeito a ação como omissão. Desde que o agente racional esteja ciente do que está fazendo, omissão também será uma forma de ação (81). O preceito fica, então, assim redigido: Não é permissível culpar alguém por uma ação, exceto quando essa for voluntária.(82) 
Uma segunda questão se apresenta como dificuldade, de acordo com Donagan, para a coerência de sua teoria da moralidade comum - a intenção para uma ação. Se alguém executa um ato de justiça, por exemplo, a punição de um bandido por algo ruim que este realmente fez, pode fazê-lo munido apenas de seu dever de justiça, mas também pode fazê-lo por maldade, sadismo, vingança. No primeiro caso trata-se de algo coerente com os demais preceitos da moralidade comum, no segundo, não. Tal situação poderia ser formulada assim: Não é permissível fazer aquilo que não é permissível planejar, assim como não é permissível planejar o que não é permissível fazer. Do que se conclui não ser permissível fazer mesmo o que for correto, se pela razão errada.(83)

A atribuição de culpa a uma ação também dependerá da ignorância do agente moral quanto a seu ato ser permissível ou não pela moralidade comum. Ao contrário da abordagem legal, portanto, que desconsidera a ignorância de uma lei como justificativa aceitável para seu descumprimento, a moralidade admite tal possibilidade, desde que tal ignorância seja genuína e não voluntária.(84)

No que diga respeito à consciência, se a definirmos seguindo Tomás de Aquino, a saber, como derivada de uma disposição de razão humana ordinária, teremos o seguinte preceito de segunda ordem: será moralmente condenável aquele que agir contra sua própria consciência, assim como quem coagir outrem a agir contra sua própria consciência (85). Donagan reconhece alguns problemas com esse preceito de segunda ordem. Primeiro, o exemplo de negar-se a participar de uma guerra "justa". E ainda a 'consciência corrompida', que pode tanto ser individual, quanto coletiva (86). Embora Donagan não considere tais problemas insolúveis, é fácil perceber que o são. Se a "consciência corrompida" pode ser coletiva, quem decide que é corrompida? Quem aplica o preceito de segunda ordem julgando a todo resto como moralmente condenável? $\mathrm{E}$, obviamente, quem decide que uma guerra é "justa"?

\subsubsection{Consistência da Proposta Para uma Teoria Moral de Alan Donagan}

Donagan aceita o desafio de submeter sua proposta de uma teoria moral ao crivo de testes de consistência. Tais testes consistem em quatro abordagens críticas possíveis a qualquer teoria moral, acredita Donagan: 1- Perplexidade moral; 2- Fazer 
o mal para alcançar o bem; 3- A teoria do duplo efeito; 4- Problemas malthusianos.

\subsubsection{Perplexidade Moral}

De acordo com Donagan, a consistência de um sistema moral pode ser posta à prova por meio de um artifício de argumentação desenvolvido por Tomás de Aquino, por sua vez derivado do conceito de "perplexidade moral" desenvolvido por São Gregório, que pondera que um sistema moral estará em cheque caso permita acontecer que uma pessoa só possa corrigir um pecado por meio de outro. A saída proposta para a moralidade comum cristã encontrada por Tomás de Aquino, de acordo com Donagan, seria diferenciar a perplexidade moral primária ( simpliciter) da perplexidade moral secundária (secundum quid). (87)

Nesse ponto vale fazer um esclarecimento. Embora Alan Donagan credite o argumento a Tomás de Aquino, a forma como ele é desenvolvido por ele (Donagan) não é exatamente a forma como Tomás de Aquino a aborda, se considerarmos as passagens do texto escolástico citadas por Donagan como dando suporte à sua própria argumentação, a saber: Summa Theologie I-II, 19, 6; II-II, 62, 2 obj 2; III, 646 ad 3, e De Veritae, 17, 4 ad 8.(88)

Entretanto, é digno de nota que a fórmula aquiniana usada por Donagan faz todo sentido, embora preste-se justamente para provar a inconsistência do sistema moral de Donagan, a despeito dele considerar o contrário. A "perplexidade" (que doravante trataremos como inconsistência) moral primária diferenciar-se-ia da secundária na medida em que esta se origina de uma ação moral condenável, por sua vez originada de outra ação moral condenável, enquanto aquela se origina de uma ação moral condenável causada por uma ação moral correta. Para ilustrar, se eu sou obrigado a mentir que não dei "cola" a um colega para não o prejudicar, estou colocado nessa posição porque originalmente pratiquei um ato condenável de fornecer a "cola". Tal situação, ainda que conflitante, não põe em cheque um sistema moral que condene tanto o ato de enganar ("colar" em prova) quanto causar dano a outro (ambos tiraremos zero, mas a mim a nota baixa não fará falta, enquanto para meu colega as consequências serão desastrosas), pois feriu-se a ambos os princípios. Trata-se, portanto, de uma inconsistência secundária 
(secundum quid).

O exemplo acima usado para ilustrar inconsistência secundária ( secundum quid) não é de Donagan, mas para ilustrar a inconsistência primária (simpliciter), será bastante útil o exemplo dado por ele mesmo, por causa de sua semelhança com outro, por sua vez ilustrativo da polêmica entre Kant e Benjamin Constant, sendo que tanto Kant quanto Donagan julgaram-se satisfeitos com suas refutações.

Na obra "Sobre um suposto direito de mentir por amor à humanidade", Kant refuta uma afirmação a ele dirigida pelo filósofo francês Benjamin Constant, em sua obra "A França de 1797". Diz Constant, citado por Kant(73):

O princípio moral que declara ser um dever dizer a verdade, se alguém o
tornasse incondicional e isoladamente, tornaria impossível qualquer
sociedade. Temos a prova disso nas consequências muito imediatas que
um filósofo alemão tirou desse princípio, indo até o ponto de afirmar que
uma mentira dita a um assassino que nos perguntasse se um amigo nosso
perseguido por ele não se refugiou em nossa casa seria crime.

Kant mantem sua posição de não aceitar as circunstâncias nem as consequências como relativizadoras do imperativo categórico 'não mentir'.(73)

Donagan segue caminho semelhante. Um sistema moral que tivesse dois princípios primários como 'não matar' e 'não mentir' não teria como incorrer em inconsistência primária. "É inconcebível que $X$ mate $Y$ em reação a $Z$ não mentir", sustenta Donagan. Entretanto, é fácil perceber que é, sim, concebível. Basta usar o mesmo exemplo usado por Constant, retirado de uma afirmação do próprio Kant. Se alguém for à casa de Alan Donagan com a intenção de matar uma pessoa que ele mantém escondida, e ele sabe que a pessoa que está à sua frente perguntando pelo paradeiro da outra tem a intenção de matá-la assim que a encontrar, se ele não mentir será responsável pela morte de quem estava justamente protegendo.(89)

Mesmo não sendo possível apresentar uma prova formal da consistência de sua teoria da moralidade comum, admite Donagan, é possível defendê-la a partir de suas duas principais fundamentações, acredita ele - a kantiana e a cristã (tradição judaico-cristã, porém com fundamentação teórica preponderantemente cristã, particularmente os textos de Tomás de Aquino).

No que diga respeito à fundamentação kantiana (90), além de desenvolver 
raciocínio semelhante ao filósofo alemão como exposto acima, Donagan cita uma passagem da "Metafísica dos costumes" para sustentar a impossibilidade de inconsistência primária em sua proposta moral:

Um conflito de deveres (collisio officiorum, s. obligationum) seria uma
relação entre eles pela qual um suprimiria o outro (total ou parcialmente). No
entanto, é absolutamente impensável uma colisão de deveres e obrigações
(obligationes non colliduntur) pois dever e obrigação são em geral conceitos
que expressam a necessidade prática objetiva de certas ações, e duas
regras opostas não podem ser simultaneamente necessárias, visto que,
quando agir conforme a uma é dever, então agir seg undo a contrária não
apenas não é dever algum, mas algo contrário ao dever. (91)

No que diga respeito à fundamentação cristã, Donagan se vale de dois conceitos, o princípio paulino e a teoria do duplo efeito. O primeiro é retirado da Bíblia (Romanos 3:8): "Não é permissível que se faça o mal, ainda que um bem advenha disso" (92). O segundo tem sua origem traçada por Donagan na formulação de um jesuíta do século XIX, J.P. Gury:

É legítimo perpetrar uma causa moralmente boa ou indiferente a partir da qual se seguem dois efeitos, um bom e um ruim, se houver uma razão proporcionalmente séria, e se o fim último do agente for bom, e o efeito ruim não for um meio para se alcançar o efeito bom. (93)

\subsubsection{Fazer o Mal para Alcançar o Bem}

Donagan rechaça o raciocínio consequencialista de se admitir como moralmente aceitável, e até mesmo desejável, a depender da situação, que se faça algo moralmente condenável como forma inevitável para se alcançar um bem maior. E o faz como base no que chama de princípio paulino. Mas isso não bastaria, admite Donagan, se a moralidade comum permitisse a possibilidade de uma inconsistência primária, o que não acontece, acredita ele, como exposto anteriormente.

Estar numa posição de escolher entre dois males, o menor, será sempre consequência de um conflito do tipo secundum quid, ou seja, se estou numa situação de erro, é porque me coloquei assim a partir de um outro erro. Donagan admite que em tais situações é desejável que se escolha o mal menor, já que há erros mais e menos graves. Roubar é menos grave do que matar, por exemplo. Mas disso não se depreende a inconsistência da teoria da moralidade comum, já que os princípios de primeira ordem permanecem intactos. 
Novamente, Donagan recorre a Kant. Os preceitos de primeira ordem de sua teoria equivaleriam aos deveres perfeitos kantianos, "que não admitem exceção aos interesses da inclinação" (94). E, voltando ao princípio paulino, seu verdadeiro sentido, pela perspectiva da moralidade comum, é o de não admitir que um mal seja perpetrado para se atingir um bem, sendo que esse 'mal' é a violação de um dever perfeito, ou preceito fundamental de primeira ordem, ainda que o bem seja um bem desejado pela própria teoria da moralidade comum, como o bem estar da própria pessoa ou de outros.(95)

\subsubsection{A Teoria do Duplo Efeito}

A teoria (ou doutrina) do duplo efeito seria uma forma de "salvar" a proposta de se fazer um mal para se atingir um bem? De certa forma, sim. Se considerarmos que aquela acrescenta a essa um detalhe: que o mal não seja, ele próprio, instrumento para se atingir um bem, mas, sim, um acidente. Donagan concordará com essa assertiva, desde que o mal em questão não seja um mal mesmo se considerado isoladamente. Tal situação é exemplificada da seguinte forma: Imaginese que um médico se coloque em risco de adquirir uma infecção ao se dispor a tratar doentes infectados. Tal exemplo é incontroverso, de acordo com Donagan, porque tornar-se exposto a uma infecção não é em si uma ação não permissível pela moralidade comum.(96)

A teoria do duplo efeito passa a ser problemática quando aplicada a casos quando o mal for não permissível quando considerado por si mesmo. Matar é errado. Matar em autodefesa não será errado em acordo com a teoria original (do jesuíta Gury) do duplo efeito pois o ato de se defender seria um, e o de matar, outro. Matar teria sido acidental, defender é que teria sido o ato original. Tal abordagem não faz muito sentido, e Donagan apresenta outra forma de se apresentar a teoria do duplo efeito, de Germain Grisez, que acrescenta a intenção no ato. Se o mal acontecido não foi instrumento (Gury) nem intenção (Grisez), e o bem é proporcionalmente sério, então está moralmente justificado. Entretanto, nenhuma dessas abordagens é necessária, acredita Donagan, pois nem faz sentido separar um ato em duas partes, nem também levar em consideração a intenção, pois basta, para a moralidade comum, que o ato tenha sido voluntário justifique-se por si mesmo. Matar em 
autodefesa é moralmente justificável não porque não houve intenção de matar para se defender, mas porque, mesmo tendo havido tal intenção, se foi em ato de autodefesa, com o objetivo de autodefesa, está moralmente justificável na medida em que o preceito fundamental respeitar o ser humano como ser racional aplica-se até o momento em que estamos diante de alguém que nos aplica violência e que por isso perde o "direito" a tal respeito. Do ponto de vista da moralidade comum, portanto, não há necessidade de se recorrer à teoria do duplo efeito para situações em que o efeito ruim (o mal) é em si mesmo justificável para se alcançar o efeito bom (o bem). Porque são uma e a mesma coisa, e esta será justificável se o for originalmente, ou seja, se for de acordo com um preceito fundamental da moralidade comum.(97)

\subsubsection{Consequencialismo}

Outra possível fonte de crítica à teoria da moralidade de Donagan seria a abordagem consequencialista. Sendo o princípio fundamental de sua teoria (Aja sempre de tal forma que você respeite cada ser humano, seja você mesmo ou outro, como sendo uma criatura racional) um dever absoluto, com pretensão incondicional e universal, é natural, ele reconhece, que haja conflitos com qualquer outra proposta que seja condicionada ao cálculo de possíveis consequências da decisão a tomar.

Donagan divide em duas as principais situações de conflito para sua teoria, a partir de abordagens consequencialistas, que ele chama de 1- Casos de necessidade e 2- O problema das mãos sujas (98). As situações que configuram "casos de necessidade" seriam as que tipicamente afloram em extremos de dilemas morais, tais como os populares experimentos mentais em que uma decisão dramática precisa ser tomada, cujas consequências podem ser a morte de poucos ou de muitos. A seguir a lógica de tais argumentos, a teoria da moralidade de Donagan (ou qualquer outra que se pretenda absoluta e incondicional) cairia por terra. Donagan, entretanto, refuta tais argumentos com uma afirmação no mínimo instigante. Além do fato de se tratar de situações teóricas raramente existentes na prática, quando for o caso, sendo a consequência (de se tomar a decisão baseado em sua teoria da moralidade) uma tragédia, e tragédias fazem parte da vida. 
Quanto às "mãos sujas", Donagan não considera pertinente o argumento de que pessoas que ocupam funções públicas tenham a prerrogativa de fazer seja lá o que for necessário, inclusive "sujar as mãos", para trazer algum benefício a sua comunidade. Entre os exemplos, o mais extremo seria o de poder torturar alguém para evitar a morte de muitos. E aqui ele entra em contradição. Embora julgando a tortura "abominável", aceita a hipótese dentro da moralidade comum, desde que se tenha certeza de que o prisioneiro a ser torturado detém a informação para se salvar as muitas vidas que serão perdidas caso o plano terrorista seja levado a termo (99). Ora, pois sua conclusão final acerca do consequencialismo (em suas diferentes versões de utilitarismo) é de que não é apenas um erro, mas também fútil, justamente por acreditar ser impossível realizar os cálculos necessários de todas as consequências possíveis de um ato (100). Da mesma forma que jamais será possível calcular todas as possibilidades de um ato, também jamais será possível ter certeza de que alguém detém uma informação e, a partir disso, tornar moralmente justificável uma tortura.

\subsubsection{Pode a Razão Ser Prática?}

Após percorrer e refutar as possíveis abordagens críticas à sua teoria da moralidade comum, Alan Donagan decide enfrentar aquela que pode ser a decisiva, a saber, se o princípio fundamental da moralidade pressupõe que a razão, se funcionar sem erro, prescreverá ações de determinada natureza (respeitar todas as criaturas racionais) de forma incondicional. Tal princípio, por sua vez, pressupõe que a razão seja prática, ou seja, se funcionar sem erro tomará as decisões corretas quanto ao que deve ou não deve ser feito.

A base da fundamentação de Donagan (101) é declaradamente kantiana:

As considerações tradicionais a partir das quais Kant aceitou o princípio fundamental [da moralidade comum], que estão implícitas nos escritos anteriores tanto hebreus quanto estoicos, têm raramente falhado em mover as mentes dos que estão dispostos a refletirem acerca delas.

Aqui vale recorrer diretamente a Kant (102):

Ora, todos os imperativos ordenam ou hipotética ou categoricamente. Os hipotéticos representam a necessidade prática de uma ação possível como meio de alcançar qualquer outra coisa que se quer (ou que é possível que 
se queira). O imperativo categórico seria aquele que nos representasse uma ação como objetivamente necessária por si mesma, sem relação com outra finalidade.

Os imperativos hipotéticos seriam, então, condicionados, os categóricos, não. Os hipotéticos, por sua vez, poderiam ser "de destreza (ou habilidade)" e "de prudência". De destreza quando se referem aos meios necessários para se alcançar um fim, independente de que fim seja. O exemplo escolhido por Kant ilustra bem isso. Ao escolher os meios necessários para alcançar a cura (um médico) ou a morte (um envenenador), um e outro estão obedecendo ao imperativo hipotético de destreza. Se o fim almejado é a própria felicidade, ao escolher os meios necessários para isso, obedecemos o imperativo hipotético de prudência.(103)

O imperativo categórico, ao contrário do hipotético, não é condicionado a coisa alguma, deve-se "buscar totalmente a prior" sua possibilidade (104). "O imperativo categórico é portanto só um único, que é este: Age apenas segundo uma máxima tal que possas ao mesmo tempo querer que ela se torne lei universal".(105)

Os imperativos hipotéticos não têm conteúdo moral, o categórico, sim. Um ponto chave para Kant (e Donagan) é a consideração dos seres racionais como fins em si mesmos, nunca como meios. Do que se depreende um "princípio prático supremo" (próximo do princípio fundamental de Donagan): "Age de tal maneira que uses a humanidade, tanto na tua pessoa como na pessoa de qualquer outro, sempre e simultaneamente como fim e nunca simplesmente como meio". (106)

Voltando a Donagan e sua questão-chave. Existe de fato uma razão prática, no sentido de chegar forçosamente ao princípio fundamental da moralidade comum, se "funcionar corretamente"? Mas o que é "funcionar corretamente"? É ser logicamente coerente, de acordo com Donagan, para quem a consistência de qualquer teoria moral (e certamente a sua própria) é cara. Interessantemente, é o próprio Donagan quem fornece a arma contra si, ao apresentar o argumento simples, porém agudo da filósofa Philipa Foot, para quem o fato de alguém rejeitar a moralidade não pode ser considerado como um ato irracional. Pode até ser acusado de vilania, mas não (necessariamente) de irracionalidade (107). Foot (108), em seu artigo original, vai além. Para a filósofa, considerar imperativos morais como categóricos e fundamentados na razão é ilusório, pois, na verdade, o que dá força a imperativos morais é o sentimento de que tais imperativos têm força, e não a razão. 
Diante do exposto, pode-se concluir que a teoria da moralidade comum de Alan Donagan, apesar de sua inspiração simples (tradição judaico-cristã) e fundamentação cuidadosa (essencialmente kantiana), não se sustenta como pretende, a saber, uma proposta ética universalista sólida.

\subsection{A TEORIA MORAL DE WILLIAM DAVID ROSS}

Embora tenha sido citado por Beauchamp e Childress (6), ao lado de Bernard Gert e Alan Donagan, como autor de uma proposta teórica de moralidade comum, W.D. Ross, um conhecido tradutor de Aristóteles para a língua inglesa, não tem, em sentido estrito, tal proposta. Sua principal obra de filosofia moral, Foundations of Ethics (3), em nenhum momento sequer usa o termo. Apesar disso, há, de fato, várias semelhanças entre as propostas de Ross e de Beauchamp e Childress.

Ross inicia sua abordagem declarando seu ponto de partida: a consciência moral. Por consciência moral ele entende as crenças e convicções das pessoas a respeito do que tem de ser feito e de coisas que precisam existir, desde que se tenha a capacidade para tal. Defendendo-se de possíveis estranhamentos pelo ponto de partida escolhido, Ross cita Aristóteles e Kant, que também lançaram mão desse artifício.(109)

De Aristóteles (110), o livro VII (1145 b) de "Ética a Nicômaco":

A exemplo do que fizemos em todos os outros casos, passaremos em revista os fatos observados e, após discutir as dificuldades, trataremos de provar, se possível, a verdade de todas as opiniões comuns a respeito desses afetos da mente - senão de todas, pelo menos do maior número e das mais autorizadas; porque, se refutarmos as objeções e deixarmos intatas as opiniões comuns, teremos provado suficientemente a tese.

De Kant (111), o prefácio da "Fundamentação da metafísica dos costumes":

O método que adotei neste escrito é o que creio mais conveniente, uma vez que se queira percorrer o caminho analiticamente do conhecimento vulgar para a determinação do princípio supremo desse conhecimento, e em seguida e em sentido inverso, sinteticamente, do exame deste princípio e das suas fontes para o conhecimento vulgar onde se encontra a sua aplicação.

A Ross não passa despercebido o detalhe "senão de todas, pelo menos do maior número e das mais autorizadas". Seriam as mais autorizadas as opiniões de 
sábios, enfim, de filósofos. Ross (109) acredita que as teorias filosóficas não estão completamente erradas, mas todas apresentam algum tipo de distorção da verdade por conta das diferentes perspectivas assumidas.

A ética de Ross será baseada na construção da opinião comum acerca do que é bom e correto. E a opinião do que é bom e correto pode se formar tanto a partir de considerações de dever, quanto de considerações de fins a serem almejados. Embora se trate de considerações diversas e até mesmo antagônicas, não se pode dizer, acredita Ross, que uma não se vale eventualmente de instrumentos da outra, assim como não é possível decretar uma ou outra como a válida e isenta de falhas. (109)

Uma outra forma de se classificar as abordagens à ética é, seguindo G.E.Moore, em naturalísticas e não naturalísticas. Ross sustenta que tanto as considerações de dever quanto as de fim podem ser naturalísticas e nãonaturalísticas. As palavras associadas às abordagens a partir de considerações de dever são, principalmente, 'correto', 'obrigatório', além de 'dever'. As palavras associadas às abordagens a partir de considerações de fim seriam, por sua vez, 'bom', 'nobre' e 'valoroso', principalmente. Ross admite que é possível que se considere 'bom' e 'correto' como a mesma coisa, moralmente falando, mas ele considera que elas definem características diferentes. (109)

\subsubsection{Definições Naturalísticas de "Correto"}

A primeira tarefa que Ross (112) se impõe é analisar (e refutar) algumas definições do que seja moralmente correto. A abordagem evolucionista, que considera correto aquilo que é evoluído é equivocada, acredita Ross (112), pois ainda que se considere características típicas de "ser evoluído" tais como "mais complexo" ou "mais recente" como positivas, nada as liga, necessariamente, ao conceito do que vem a ser correto no sentido moral. $O$ que não significa dizer que o fato do ser humano ter ficado mais altruísta e menos egoísta e, consequentemente, uma característica moral positiva (a saber, preocupar-se com o bem estar dos outros) não possa ser tomado como moralmente louvável. Entretanto, disso não decorre que moralmente correto seja o que é evoluído. 
Outro aspecto a que as teorias evolutivas da moralidade podem levar, de acordo com Ross (112) é a crença de que não há uma verdade moral. O que é correto variará de acordo com as diferentes culturas e até mesmo dentro de uma mesma cultura. Ross defende que as comunidades (ou as pessoas) não divergem acerca de princípios fundamentais, mas, sim, acerca de sua interpretação e/ou a partir de seu conhecimento das particularidades de cada situação. Entre os exemplos dados por Ross (apropriados do filósofo inglês Alfred Edward Taylor) um é até bem pertinente e sustenta seu ponto com sucesso. Trata-se da vacinação de crianças. Pais podem ser contra ou a favor, não porque divergem do princípio fundamental "é dever dos pais proteger a saúde dos filhos", mas por considerar, por conhecimento ou falta dele, que a vacina fará mal (os contra) e não bem (os a favor).

Aqui vale fazer pequena pausa na análise da proposta de Ross, para comentar rapidamente acerca das propostas de moralidade comum em geral. Um dos maiores problemas enfrentados por todas elas são sua crença (na falta de melhor termo) na existência de princípios fundamentais universais imunes e não condicionados a diferenças geográficas, culturais, históricas. Cada uma apresenta sua saída para esse labirinto. A de Beauchamp e Childress será analisada mais adiante. A de Ross, com o exemplo da vacina, parece, à primeira vista, satisfatória. Mas será ele próprio, com seus outros exemplos, que a jogará por terra.

Voltando, então, à Ross (112), punição com morte é outro exemplo fornecido por ele (também a partir de A. E. Taylor) como tendo o princípio fundamental intacto e apenas a particularidade em conflito. Em sociedades menos desenvolvidas, punição com morte, por vingança, pode ser (ter sido) a única forma de se garantir o princípio fundamental de respeito à vida. Não é difícil perceber como tal exemplo é problemático. Até porque, ainda hoje se pune com morte, e não é de forma alguma aceitável o argumento de que se o faz por ser a única maneira de se garantir o princípio fundamental de respeito à vida. Menos difícil ainda será imaginar várias outras situações. Por exemplo, que princípio fundamental está sendo obedecido quando se considera moralmente correto apedrejar mulheres que praticam adultério? Ou quando se condena moral e/ou legalmente uniões homoafetivas? Ou quando se declara uma guerra?

O próximo alvo de Ross (112) são as fundamentações naturalísticas do que 
seja moralmente correto a partir do que ele chama de "teorias de atitudes mentais". Tais teorias defendem que correto é o que provoca no agente a sensação de aprovação. Entretanto, aprovação é um termo muito vago, lembra Ross, não servindo, pois, de baliza para a determinação do que seja moralmente correto. que não exclui que de fato se tenha a sensação aprazível de autoaprovação quando se realiza algo moralmente correto, mas disso não se depreende que uma a primeira defina o segundo.

Tal consideração valeria ainda para a aprovação pública. Não apenas não se pode definir como correto aquilo que o próprio agente aprova, como também aquilo que os demais aprovam. Pelo menos não necessariamente. De fato, pode até ser o caso do contrário. Ross lembra bem o caso da escravatura. As primeiras vozes que ousaram se levantar contra foram ouvidas pela maioria com indiferença, espanto ou até reprovação. Tratava-se de uma ruptura com o pensamento preponderante da época, consequentemente, o que gozava do status de aprovação era a escravatura, e não seu contrário. Aprovação, privada ou pública, não servirá, portanto, como critério de definição para o que seja moralmente correto.

Em seguida, Ross (3) analisa as propostas de representantes da "escola positivista de Viena", os filósofos Carnap e Ayer, concluindo que sua abordagem a partir do empiricismo (será moralmente correto o que puder ser empiricamente observado como tal) também carece de sustentação:

Sua objeção a reconhecer julgamentos éticos como asserções genuínas vem do fato, há muito conhecido dos filósofos morais, que julgamentos éticos não podem ser verificados pela experiência dos sentidos, associada a visão dos positivistas de que os únicos julgamentos sintéticos que têm significado, ou seja, que são genuínos, são aqueles verificáveis (posição 840).

\subsubsection{Definições Não Naturalísticas de 'Correto'}

Para uma definição não naturalística do 'moralmente correto', Ross se vale da proposta do filósofo inglês Charlie Dunbar Broad, particularmente sua obra Five Types of Ethical Theory, de 1930. Concordando com Broad, Ross apresenta as diferentes possibilidades de significado da palavra 'deve' (ought). Esta poderia assumir um sentido estrito e um sentido amplo. Em seu sentido estrito se aplicaria apenas a ações as quais o agente poderia fazer se quisesse. Já em seu sentido 
amplo tal condição ("se quisesse") não se aplica. O exemplo de ambos, Ross e Broad, é de alguém que 'deve' sentir tristeza pela morte de um parente, sendo que não está em seu poder querer sentir ou não. Está claro que tal sentido amplo à palavra "deve", ainda que utilizado vulgarmente, é inapropriado.(113)

Broad apresenta ainda, de acordo com Ross, outra divisão da palavra "dever", com três possibilidades de sentido: deontológico, teleológico e lógico (114). A primeira aplicação da palavra "dever", deontológica, seria o caso quando se considera que a ação que deve ser feita deve sê-lo independente de suas consequências serem potencialmente boas ou más. A aplicação teleológica será aquela em que o deve ser feito deve sê-lo tendo sempre em vista um determinado fim almejado. A aplicação lógica, por sua vez, seria aquela em que a ação a ser feita deve ser tal que seja consistente com o fim almejado. Essa última guarda semelhança com o imperativo hipotético kantiano, citado por Alan Donagan.Broad (e Ross) considera que a aplicação teleológica de "dever" tem sentido amplo, e as aplicações deontológica e lógica, sentido estrito (115). Disso se segue que a aplicação teleológica para dever é inapropriada, e também a lógica, pois esta, embora tenha sentido estrito, não traz em si um sentido moral. Ficamos, então, com a aplicação deontológica de dever como sendo a única apropriada. Novamente, pode-se tração uma semelhança com a proposta kantiana, se considerarmos a aplicação lógica como imperativo hipotético, e a aplicação deontológica, imperativo categórico.

Há certa relação entre as palavras "dever" e "correto", embora não se deva esquecer a possibilidade de mais de uma ação ser correta e nenhuma delas ser propriamente obrigatória (116). Correto seria algo que é apropriado para determinada situação. Aqui Ross enfatiza uma diferença entre "correto" e "bom", a partir da analogia com uma estrada. Uma estrada pode ser boa e não necessariamente correta, e vice-versa (117). Assim também pode ocorrer com emoções, como "benevolência" e "tristeza". A primeira, intrinsecamente boa, será sempre correta, enquanto a segunda será a emoção moralmente correta for o caso, por exemplo de tristeza pelo infortúnio de alguém, mas moralmente errada, quando for tristeza motivada pelo sucesso de um inimigo, por exemplo.

A analogia da estrada traz, porém, um problema, na visão de Ross, pois tem 
como consequência inevitável uma associação com o utilitarismo. "Ser correto" como "ser apropriado" não pode ter conotação utilitarista, defende Ross. Outra associação possível é a estética: seria moralmente apropriado o que é esteticamente apropriado. Para Ross (e Broad) tal associação é mais pertinente do que a utilitarista, pois remete ao conceito de harmonia. O que é correto é harmônico (118). Ross, por fim, conclui ser o termo "correto" usado de forma bastante fluida (embora sempre envolvendo o sentido de "apropriado"), mas também frequentemente associado a um sentido de dever, de obrigação (como em sentenças "O correto a fazer é isso").

Com relação a considerar as teorias utilitaristas como propostas não naturalistas, vale esclarecer que Ross considera o utilitarismo clássico, a partir de Bentham e Mill, que associa o "bem" a algo externo a ele (como "prazer") como naturalistas. O utilitarismo não naturalista que Ross tem em mente é o de Moore, um utilitarismo idealista.

Ross refuta as abordagens utilitaristas, mas não completamente. Considerando que todas carregam consigo alguma forma de intuicionismo, e sendo o intuicionismo a abordagem considerada por ele a que mais se aproxima da correta, sempre haverá certas características do utilitarismo aproveitáveis, desde que não se perca de vista suas deficiências (discutidas anteriormente e a seguir). Por intuicionismo, Ross entende "entre as características de uma situação que tendem a fazem de um ato o correto, há algumas que independem da tendência desse ato de produzir o máximo de bem". (119)

Ao discutir as possíveis objeções ao intuicionismo, Ross novamente aponta falhas do utilitarismo e, mais importante, introduz um conceito-chave de sua teoria, e que guarda íntima relação com a abordagem bioética de Beauchamp e Childress as obrigações prima facie.

\subsubsection{Obrigações Prima Facie}

As objeções que existem ao intuicionismo adviriam essencialmente do estranhamento que causa o fato de admitir, de acordo com Ross, que haja várias possíveis intuições morais, inclusive agindo simultaneamente. Existir uma única 
intuição moral, tal como a proposta pelo utilitarismo (seja hedonista, seja idealista), satisfaria nossa angústia de ter uma única e simples proposta moral, à qual toda correção ou incorreção de um ato pudesse ser reduzida (120). Entretanto, sustenta Ross, é mais importante que uma teoria moral seja verdadeira do que simples. $\mathrm{E}$ definir o que seja correto apenas pelo cálculo do que gere mais bem é incompleto e insatisfatório.

$\mathrm{Na}$ mesma linha, outra objeção seria a de que o fato de serem possíveis várias intuições morais diferentes e estas poderem coexistir leva à inevitável consequência de que entrem em conflito. Ross admite essa possibilidade, mas é aqui que entra o conceito de obrigações prima facie. Sim, é possível que em determinada circunstância obrigações colidam, mas a decisão quanto à correta a seguir advirá da avaliação da totalidade dos aspectos envolvidos nessa dada circunstância.(121)

Para tornar sua abordagem mais clara, Ross (3) faz uma analogia com as leis da física:

\begin{abstract}
Quando tentamos formular uma lei da natureza, consideramos que, para formulá-las de maneira que não admitam nenhuma exceção, devemos formulá-las não como leis de operação real, mas como leis de tendência. Não podemos dizer, por exemplo, que uma certa força impingida num certo corpo de certa massa, sempre fará com que este se mova com certa velocidade na direção da linha de força; pois se o corpo sofrer ação oposta de mesma força, permanecerá em repouso; e se sofrer uma ação de força em uma terceira direção, mover-se-á numa linha oblíqua à linhas das duas outras forças. $O$ que podemos dizer então é apenas que qualquer força tende a fazer um corpo se mover na linha da força. [Destaque de Ross]. Dessa forma temos uma perfeita lei natural. Da mesma forma, se quisermos formular leis morais universais, só as poderemos formular como leis de obrigação prima facie, [ou seja], leis que afirmam as tendências das ações como sendo obrigatórias em virtude dessa ou daquela característica. É a desconsideração da diferença entre obrigações e responsabilidades, [ou seja] entre obrigatoriedades reais e a tendência a ser obrigatório, que leva ao problema de conflito de deveres, e é pela distinção [entre obrigatório e tendência a ser obrigatório] que resolvemos o problema, ou melhor, que demonstramo-lo inexistente. Pois, enquanto um ato pode ser prima facie obrigatório, em respeito a um aspecto e prima facie proibido em virtude de outro, torna-se obrigatório ou proibido apenas em virtude da totalidade de suas características eticamente relevantes. Nós estamos perfeitamente familiarizados como essa forma de pensar quando nos deparamos com problemas reais de conduta, mas em teorias éticas as responsabilidades tem sido frequentemente hiperestimadas como sendo obrigações absolutas que não admitem exceção, e dessa forma o problema irreal de conflito de deveres tem sido suposto existir. (122)
\end{abstract}

Os deveres prima facie seriam, de acordo com Ross (123): 
1- Fidelidade (não quebrar promessas).

2- Reparação (quando fazemos mal a alguém).

3- Gratidão.

4- Não-maleficência (evitar causar danos a outros, sejam físicos ou psicológicos).

5- Beneficência (devemos ser gentis com os outros e tentar contribuir para seu melhoramento (saúde, sabedoria, segurança, felicidade, bem-estar).

\section{6- Automelhoramento.}

7- Justiça.

Nota-se aqui que três dos princípios de Beauchamp e Childress estão entre os deveres prima facie de Ross, faltando apenas respeito à autonomia, embora a forma como beneficência é colocada poderia abarcar respeito à autonomia. E, assim como Beauchamp e Childress alegam não haver uma hierarquia de princípios, também Ross.

Assim como Alan Donagan fez referência a Kant no que se refere à possibilidade de conflito de deveres, também Ross. Donagan concorda com Kant (124), quando este afirma:

\footnotetext{
Um conflito de deveres (collisio officiorum, s. obligationum) seria uma relação entre eles pela qual um suprimiria o outro (total ou parcialmente). No entanto, é absolutamente impensável uma colisão de deveres e obrigações (obligationes non colliduntur) pois dever e obrigação são em geral conceitos que expressam a necessidade prática objetiva de certas ações, e duas regras opostas não podem ser simultaneamente necessárias, visto que, quando agir conforme a uma é dever, então agir segundo a contrária não apenas não é dever algum, mas algo contrário ao dever. (125)
}

Já Ross discorda. Para ele, é bastante natural que deveres, quando se contradigam, um prevaleça sobre o outro, considerados todos os aspectos moralmente relevantes. Assim como também o será se, em outra situação, prevalecer o que antes havia sucumbido. Dessa forma, a posição de Ross é diametralmente oposta a de Donagan (e, consequentemente, Kant), pois aquele não considera que a pluralidade de princípios morais provoque uma inconsistência do 
sistema moral proposto (126), desde que se compreenda sua natureza prima facie. Princípios absolutos caem no inevitável labirinto do conflito de obrigações. Como posso manter minha promessa se, ao levá-la a cabo, provocarei uma morte? Não é difícil ao senso comum enxergar que o princípio (dever) "não quebrar promessas" nesse caso sucumbe ao princípio "não causar dano".

Ross (126) também apela ao senso comum, dessa vez tomado como bom senso, para a interpretação das circunstâncias que envolvem um dever. Uma promessa, por exemplo, pode ter diversas nuances que podem provocar diferentes interpretações. Se alguém promete a outrem que irá à sua casa em tal dia e hora, mas, nesse dia e hora cai doente, certamente não está obrigado a cumprir sua promessa. Para Ross, então, a consideração da totalidade dos aspectos que envolvem um dever abarca não só a eventual contraposição de um dever a outro, como as circunstâncias alheias à vontade do agente, não necessariamente com relevância moral, como é o caso do exemplo de cair doente e por isso não ter como cumprir o dever de realizar o ato prometido. Como se vê, Ross dá grande valor ao senso comum na construção de sua teoria moral, o que não é propriamente a mesma coisa de uma moralidade comum, embora também não sejam coisas distantes.

Tal característica da proposta de Ross (126) é importante por distingui-la de outras propostas deontológicas. É deontológica na medida em que considera o dever como seu ponto central, em contraposição a propostas teleológicas, particularmente o utilitarismo, que tem na maximização do bem seu ponto central. Mas é importante frisar que não se trata de um deontologismo no sentido kantiano, adotando princípios absolutos, pois não só admite a natureza prima facie dos deveres, como leva em consideração a totalidade dos aspectos envolvidos num dever, tal como os homens comuns praticam em seu dia a dia.

Nesse ponto vale discutir uma interpretação da proposta de Ross para ajudar a clareá-la. William Frankena, em sua obra Ethics, propõe uma classificação para as teorias deontológicas como "de ato" e "de regra". As de ato seriam as que dizem que como "Nessa situação eu devo fazer tal coisa", e que [julgamentos] gerais tais como "Nós devemos sempre manter nossas promessas" são inúteis, ou, na melhor das hipóteses, derivados de julgamentos particulares. (127) 
O julgamento final caberia, pois, à intuição. Uma variante seria o julgamento delegado a uma escolha, nesse caso a posição típica dos existencialistas. Estranhamente, Frankena não inclui Ross entre os intuicionistas, classificando-o a seguir no segundo tipo de teoria deontológica, a "de regra", onde também inclui Kant.

Frankena comete um equívoco, pois a teoria deontológica de Ross tem características que Frankena atribui a ambas as divisões propostas por ele. Nesse sentido, Canto-Sperber e Ogien (128) foram mais felizes. Incluem Ross dentro da categoria das "Teorias do dever", ao lado de Kant, mas distinguem-no deste justamente por seu intuicionismo, além, claro, do caráter prima facie de seus deveres. Frankena reconhece e até concorda com o caráter prima facie de deveres da proposta de Ross (embora propondo sua própria teoria), mas desconsidera essa outra característica importante, a saber, de onde vêm os deveres prima facie - da intuição dos homens comuns.

Para Ross, as obrigações morais não são inferidas nem deduzidas, são intuídas, pré-teóricas (embora nada impeça sua racionalização a posteriori). O homem comum, colocado diante de situação em que precisa tomar uma decisão, já sabe o que deve fazer. $\mathrm{E}$ o fato de poder haver mais de uma coisa cabível a fazer não é problema para Ross, pois o homem comum pesará os aspectos abarcados pela situação e, entre esta e aquela obrigação (em potencial), escolherá a que prepondera para aquela situação. Não incomoda de forma alguma a Ross, uma crítica frequente à sua proposta, a saber, que ele não fornece uma hierarquia para os deveres, como um guia norteador. Além de não fazer sentido dentro de seu sistema prima facie, não coincide com a realidade do dia a dia do homem comum, na construção do senso comum. No dia a dia, o homem comum se depara com situações diferentes que, a cada vez, podem levar a decisões morais diferentes.

Ao discutir as críticas ao seu intuicionismo, Ross pondera:

Agora, o intuicionismo, tal como eu o concebo, não condena, de forma alguma, a vida moral à rotina. Tal acusação poderia ser imposta ao intuicionismo de Kant, que sustenta que a correção ou incorreção [moral] de um ato pode ser inferida com certeza a partir de sua obediência ou não a uma regra capaz de ser universalizada. Minha crítica dessa visão é que injustificadamente simplifica a vida moral. Ignora o fato de que em muitas situações há mais de uma exigência sobre nossa ação, que tais exigências frequentemente conflitam, e que, enquanto podemos ver com clareza que 
tais exigências existem, torna-se matéria de julgamento individual e falível o dizer qual exigência em tais circunstâncias deve preponderar. Em várias situações, homens igualmente bons formam julgamentos diferentes sobre qual é seu dever. Eles não podem estar todos certos, mas é frequentemente impossível dizer qual está certo; mas cada pessoa deve julgar de acordo com seu senso individual da força comparativa das diferentes exigências. (129)

Tais afirmações remetem à reflexão dostoievskiana em Os irmãos Karamazov - se Deus não existe, tudo é permitido. Parafraseando, se não existe um princípio absoluto, tudo é permitido. De toda forma, resta claro que, a despeito de em nenhum momento Ross utilizar o termo "moralidade comum", sua proposta é bastante parecida com a de Beauchamp e Childress, já que suas duas características principais (o apelo ao senso comum e o caráter prima facie de suas obrigações morais) são também as de Beauchamp e Childress. Estranho que Ross seja muito pouco citado por estes.(3) 


\section{A TEORIA DA MORALIDADE COMUM DE BEAUCHAMP E CHILDRESS}

A partir da quarta edição de Principles of Biomedical Ethics, publicada em 1994, Beauchamp e Childress passaram a lançar mão de uma teoria moral para fundamentar seus princípios de ética biomédica - a moralidade comum. A edição seguinte, publicada em 2001, caracterizou-se por uma incorporação substancial do conceito de moralidade comum como a fonte última de normas morais (130), fundamentação esta mantida na mais recente edição.(1)

\subsubsection{Moralidade comum como moralidade universal}

Os autores fazem logo questão de explicitar suas pretensões com um subtítulo de capítulo tal como posto aqui: "Moralidade comum como moralidade universal". Partindo do termo 'moralidade' compreendido como "normas sobre a conduta humana certa e errada que são tão amplamente compartilhadas que formam um compacto social estável", Beauchamp e Childress definem como 'moralidade comum' exatamente tais normas (2). Note-se que, embora os autores afirmem que o termo 'moralidade' seja mais amplo do que 'moralidade comum', não nos diferenciam ao definir o último. A ressalva é que o 'comum' diz respeito a "todas as pessoas moralmente comprometidas". Uma ponderação à primeira vista circular, mas que tem o objetivo de eliminar da equação as pessoas "amorais, imorais ou seletivamente morais". (131)

A pretendida universalidade seria uma consequência natural de todas as pessoas (moralmente comprometidas) adotarem as mesmas regras de conduta para si e os outros. Seriam estas, por exemplo, não mate, não cause dor ou sofrimento, evite que danos sejam causados a outros, ajude pessoas em perigo, diga a verdade, proveja pessoas dependentes de você, diga a verdade, mantenha suas promessas, não roube, não puna inocentes, obedeça às leis, entre outras.

Também fazem parte do núcleo da moralidade comum certos traços de caráter, ou seja, certas virtudes. Sendo a moralidade comum o conjunto de normas 
tacitamente aceitas por todos, também o serão as virtudes consideradas desejáveis para possibilitar que tais normas sejam cumpridas. Assim, benevolência, honestidade, integridade, conscienciosidade, confiabilidade, fidelidade, gratidão, amorosidade, gentileza, entre outras (132), são características tidas como desejáveis no contexto da moralidade comum.

Uma característica importante citada pelos autores é a natureza afetiva da moralidade comum. A não-observância das normas gerará "sentimento de remorso e provocará censura" (132). Aqui vale fazer breve pausa para apresentar uma proposta semelhante - de Ernst Tugendhat.

Em "Reflexões sobre o que significa justificar juízos morais" (133), Tugendhat defende não ser necessário contrapor razão e sentimento para justificar juízos morais. Será considerado moralmente correto aquilo que despertar em nós aprovação, e moralmente errado, irritação - uma "irritação moral". O que ocorre quando alguém fere uma norma reciprocamente aceita é o sentimento de culpa por parte de quem feriu, e indignação, por parte dos demais. E isso é possível porque há um acordo tácito entre todos, que formam uma 'autonomia coletiva'. Tugendhat, como Beauchamp e Childress, rechaça outras alternativas que não a universalidade como o alcance do acordo. Para Tugendhat, o conceito de autonomia coletiva não é compatível nem com uma concepção contratualista, nem comunitarista. Tal se dá porque a justificação é sempre justificação 'para', e na concepção contratualista o 'para' se refere a cada um, na comunitarista para um grupo. Somente a universalista é aceitável, pois é para todos, portanto não excludente. A proposta de Tugendhat recebeu críticas que caberiam também a Beauchamp e Childress. Voltaremos a elas oportunamente.

Beauchamp e Childress também sustentam que moralidades particulares não são a moralidade comum. Por trás destas há um núcleo, que tem autoridade sobre as moralidades das diferentes comunidades. Eles aceitam, então, o pluralismo de moralidades particulares, mas não na moralidade comum, que é universal. E é desta que derivam as normas morais da ética biomédica. Que se trata, portanto de uma fundamentação para uma ética no contexto biomédico (e não uma fundamentação bioética) é algo explicitado desde o início de Principles of biomedical ethics, assim como em momentos diferentes, ao discorrer sobre os princípios, culminando no 
último capítulo: "[...] nenhum outro conteúdo moral central existe como ponto de partida para a ética biomédica, que não os tipos de normas a partir das quais formulamos os quatro grupos de princípios" (134). O que não significa dizer que os princípios são a moralidade comum, mas, sim, que são derivados dela. Beneficência, não-maleficência, justiça e respeito à autonomia têm sua origem na moralidade comum. "Nossa tese é meramente que os princípios e as regras são uma formulação razoável de algumas normas vitais da moralidade comum, e que os princípios que analisamos são particularmente adequados à ética biomédica". (134)

\subsubsection{Especificação e ponderação}

As normas de conduta prescritas pela moralidade comum têm a característica de serem inespecíficas e abstratas. Para que sejam postas em prática precisam, portanto, de especificação e ponderação. Deste processo sairão os princípios para a ética biomédica, que, por sua vez, precisarão passar um processo de ponderação de pesos e forças que serão determinados pelas circunstâncias. Assim, a norma moral comum "diga a verdade" pode dar origem ao princípio "respeite a autonomia", que poderá ser especificado numa regra de consentimento informado.

O conflito inevitável entre os princípios, normas e regras derivados da moralidade comum para as situações de decisão (ou julgamento) em ética biomédica será resolvido pela via prima facie. Beauchamp e Childress seguem W.D. Ross em sua distinção de obrigação real e obrigação prima facie (135). Aquilo que deve ser feito (obrigação moral) será determinado pelo princípio (norma, regra) que prevalecer, após levadas em consideração todas as ponderações cabíveis.

Um elemento importante do processo de especificação é que este não pode perder de vista a norma moral comum que Ihe deu origem. "Moralidades particulares distinguem-se pela especificidade de suas normas, mas estas normas não serão moralmente justificadas se violarem as normas da moralidade comum". (131)

\subsubsection{Pluralismo}

Como mencionado anteriormente, Beauchamp e Childress aceitam o 
pluralismo de moralidades particulares, mas não na moralidade comum, que é universal. Nesse sentido, pluralismo seria entendido como relativismo. E também nesse sentido vai a constatação dos autores de que sua teoria da moralidade comum, assim como a de Bernard Gert, deve ser entendida como "uma moralidade universal, que não é relativa a culturas, indivíduos, religiões ou associações profissionais" (8). Entretanto, quando enumeram as características de teorias da moralidade comum, citam o fato de todas serem pluralistas, pois contêm princípios morais não absolutos (136). Mais adiante, já no final do último capítulo (137) referem-se ao "pluralismo conceitual", criticando-o. Este seria cometeria o erro de imaginar-se num contexto normativo, enquanto na verdade estaria inserido num contexto descritivo. Da constatação de que há várias possibilidades de conduta dependendo das diferentes culturas em que se está inserido, sairiam normas de conduta, o que seria um erro, acreditam os autores, pois levaria a normas conflitantes. Mas não seriam os princípios da moralidade comum conflitantes? E não seria justamente esta característica de não-hierarquização e possibilidade de conflito, a ser decidido prima facie, o motivo de os autores considerarem a moralidade comum uma teoria pluralista?

\subsubsection{De onde vem a moralidade comum}

A moralidade comum é pré-teórica. Baseia-se em crenças simples compartilhadas por todas as pessoas moralmente comprometidas. A teoria que se seguir daí, terá de levar isso em consideração. Uma teoria da moralidade comum, então, partirá da constatação do que já é partilhado pelas pessoas e tido como certo, desejável, bom, elogiável (ou seu contrário). Isso leva a pensar em moralidade como hábito, costume. As crenças tidas como moralmente elogiáveis/condenáveis seriam aquelas com que as pessoas estão acostumadas. Mas não é essa a visão de Beauchamp e Childress:

Nossa teoria da moralidade comum não vê moralidades costumeiras como parte da moralidade comum, ainda que possam incorporar elementos da moralidade comum. Que haja códigos costumeiros de conduta, e que estes podem diferir em crenças e práticas, são fatos indiscutíveis, mas as normas gerais na moralidade comum fornecem uma base para se avaliar e criticar pontos de vista morais costumeiros que são em certa medida deficientes. (136) 


\subsubsection{Equilíbrio reflexivo}

O que diferencia a moralidade comum da moral como simples é a incorporação do método do equilíbrio reflexivo. Termo cunhado pelo filósofo John Rawls, lembram os autores, (138) o equilíbrio reflexivo consiste na tentativa de harmonizar princípios, julgamentos e teorias de base de tal forma a torna-los coerentes. Uma forma mais ampla de equilíbrio reflexivo levaria em consideração todas as forças e fraquezas de todos os princípios, julgamentos e postulados teóricos, atingindo, idealmente, um máximo equilíbrio e coerência. Beauchamp e Childress reconhecem que isso bastante difícil, mas negam que seja impossível, e por isso deve ser sempre tentado.

Mas coerência não é uma virtude a ser considerada isoladamente. O clássico caso do código de conduta de piratas do século XVII é citado pelos autores. (139) A coerência interna desse código era grande, com regras prevendo ajuda mútua, punições para atos proibidos, forma de distribuição do butim, e assim por diante. Mas pode-se considerar um código de condutas de uma classe de pessoas cuja atividade mesma é uma conduta não aceitável para a moralidade comum? Certamente que não, o que leva à conclusão de que coerência não basta. A outra peça que falta é a moralidade comum. $O$ ponto de partida são as crenças morais bem estabelecidas, e que sejam consideradas legítimas representantes da moralidade comum, e só então é que se busca a coerência por meio do método do equilíbrio reflexivo.

O equilíbrio reflexivo, entretanto, tem problemas, reconhecem os autores. Além da já mencionada dificuldade em se atingir o ideal, há ainda a ambiguidade de foco e a decisão sobre o sucesso alcançado. Deve ser dirigido primariamente a uma construção teórica, ou ao fortalecimento de crenças morais? Quando se sabe que se chegou ao objetivo desejado?

\subsubsection{Existe mesmo uma moralidade comum?}

Beauchamp e Childress respondem a uma crítica recorrente à sua teoria da moralidade comum, a saber, que não há provas observáveis de sua real existência 
e, até pelo contrário, o que há são abundantes provas de sua impossibilidade de existência. Tais provas, argumentam eles, não são cientificamente adequadas. Para se testar experimentalmente se existe uma moralidade comum universal, seria necessário seguir um método rigoroso, e não apenas valer-se de observações empíricas. Este consistiria, em primeiro lugar, na seleção rigorosa da amostra a ser estudada. Teria obrigatoriamente de ser formada por pessoas que passam em um teste inicial rigoroso para avaliar se suas crenças estão em conformidade com algum julgamento crítico, a ser designado pelo desenho do estudo. E ainda que estas pessoas tenham a habilidade de assumir pontos de vista imparciais. (34) O método prevê incluir apenas pessoas que, num rastreamento prévio, já demonstraram ser adeptas de pelo menos uma norma da moralidade comum, e o candidato ideal seria o princípio de não-maleficência. Um desenho de pesquisa com tais características, reconhecem os próprios autores, não é somente difícil de ser executado, mas contém um enorme viés de seleção. Não teria validade científica alguma.

Independente do resultado de um estudo experimental, ou mesmo de fatos históricos ou sociais que contradigam ou reforcem a existência de normas morais universais de uma moralidade comum compartilhada, nada de normativo se seguiria. Embora Beauchamp e Childress não se valham do termo, trata-se aqui de uma referência à "falácia naturalista" (do ser não se deriva o deve ser). Por tal perspectiva, tanto faz que se prove que pessoas tenham de fato um núcleo de crenças morais compartilhadas ao qual se dará o nome de moralidade comum para que se construa um sistema de normas a partir de tais crenças. Mas então cabe a pergunta: como criar todo um sistema de normas, regras e princípios a partir de algo que não existe? Ou tal sistema não precisava se fundamentar em teoria alguma, ou sua fundamentação é extremamente frágil. Ambas as hipóteses são bastante problemáticas. A primeira é o caso de um sistema completamente arbitrário, cuja legitimidade se daria por meio de uma autoridade normativa como proposta para um conjunto de normas de conduta em contexto biomédico. A segunda teria sua legitimidade constantemente questionada. E é precisamente esse o caso da teria da moralidade comum como fundamentação da ética biomédica de Beauchamp e Childress. 


\subsection{Beneficência}

O capítulo sobre o princípio da beneficência abre com a afirmação: "Moralidade requer não somente que tratemos as pessoas autônomas e não lhes causemos mal, como também que contribuamos para seu bem-estar" (140). Profissionais de saúde têm o dever moral não somente de não causar mal, mas contribuir ativamente para o bem daqueles sob seus cuidados. Tal função seria exercida, no nível coletivo, pela medicina preventiva, saúde pública e pesquisa biomédica.

Beauchamp e Childress apresentam duas possibilidades para o princípio de beneficência, a saber, beneficência positiva e utilidade. A positiva requer do agente que ativamente promova o bem de outros. Já a utilidade deve primeiro fazer seus cálculos para chegar ao melhor resultado em potencial. (140)

Os autores esclarecem que beneficência, benevolência e princípio de beneficência não são a mesma coisa. O primeiro termo aplicar-se-ia de forma mais geral a atos com a intenção de beneficiar outros. O segundo equivaleria a um traço de caráter, uma virtude. Nenhum dos dois primeiros, portanto, seriam obrigações morais. Apenas o princípio de beneficência poderia ser considerado como tal. Porém, não com o mesmo peso dado pelos utilitaristas, entre os quais Beauchamp e Childress citam especificamente Hutcheson e Hume, cujas "teorias de moralidade comum" fundamentam-se na beneficência. O princípio de utilidade que dá sustentação ao princípio de beneficência de Beauchamp e Childress, portanto, não é o mesmo que o utilitarismo, particularmente porque é um entre outros, a se impor (ou não) prima facie, e não como fundamentação última. (141)

Admitindo a premissa de que atos de beneficência não constituem dever moral, Beauchamp e Childress enumeram algumas obrigações prima facie que dariam suporte ao princípio de beneficência que chamam de "positiva". Estes seriam: 1- Proteger e defender os direitos dos outros. 2- Evitar que danos ocorram a outros.

3- Remover condições que causem danos a outros. 4- Ajudar outros com deficiências. 5- Resgatar pessoas em perigo.

Beachamp e Childress distinguem regras de beneficência e não-maleficência. 
As últimas seriam proibições negativas, que devem ser seguidas imparcialmente e têm força para fundamentar punições legais. As primeiras seriam exigências positivas de ações, embora não necessariamente imparciais, que de forma geral não têm força para fundamentar punições legais. Aqui Beauchamp e Childress dialogam com Clouser e Gert sem citá-los. Estes, ao criticarem a segunda edição de Principles of Biomedical Ethics, alertam para a impossibilidade de o princípio de beneficência ser um dever moral, pois um dever moral é imparcial por natureza, e a beneficência não teria como sê-lo (142). Curiosamente, tal é a crítica que os próprios Beauchamp e Childress fazem a outro autor, W.D. Ross: "A noção de que temos as mesmas obrigações imparciais de beneficência a pessoas que não conhecemos e às que conhecemos é bastante romântica e impraticável". A solução para o problema seria, de acordo com os autores, a distinção entre beneficência geral e específica. Esta, típica das relações entre profissionais de saúde e seus pacientes (entre outras), enquanto aquela seria uma beneficência de forma ampla, sem alvos préestabelecidos. A específica seria um dever, a geral, um ideal.

Mas não apenas as relações profissionais na área da saúde que configuram o princípio da beneficência como dever moral. Beauchamp e Childress estabelecem cinco condições que, uma vez presentes, fazem com que um ato de beneficência deixe de ser um simples ideal e passe a ser uma obrigação. Seriam elas:

1- Y está em risco de perda significativa ou dano à vida, saúde, ou algum interesse básico. 2- A ação de $X$ é necessária (individualmente ou em conjunto com outros) para prevenir a perda ou dano. 3- A ação de X (individualmente ou em conjunto com outros) provavelmente evitará a perda ou dano. 4- $A$ ação de $X$ não apresenta riscos significativos, custos ou fardo pesado. 5- $O$ benefício que se espera para $Y$ sobrepuja qualquer dano, custo ou fardo que provavelmente recairá sobre X. (143)

\subsubsection{O princípio da beneficência aplicado à pesquisa biomédica}

Beauchamp e Childress abordam duas situações em pesquisa biomédica às quais o princípio da beneficência poderia vir a ter o peso de dever moral. A primeira seria o acesso expandido, que poderia, ou não, preencher todas as cinco condições propostas para se configurar em uma obrigação. Neste caso, lembram que a condição número 3 pode não ser alcançada por se tratar de pesquisa de drogas cuja eficácia e segurança não estão ainda plenamente comprovadas. A segunda situação 
é o caso do acesso à droga em estudo após finalizada pesquisa (ou a participação do sujeito na pesquisa). Vale lembrar que tal situação é alvo de controvérsia entre países ricos e países periféricos. A posição hegemônica, ilustrada pela última versão da Declaração de Helsinki, é a de que não se configura uma obrigação moral. A posição contra-hegemônica, adotada inclusive oficialmente pelo Brasil, por meio da resolução CNS 466/12, é de ser, sim, uma obrigação moral. Por sua vez, Beauchamp e Childress não adotam uma posição definitiva nem para um lado, nem para outro. Embora iniciem dizendo que "o problema do acesso contínuo é como identificar as condições sob as quais é moralmente obrigatório" (144), seguem concordando que há base suficiente para que o seja. Entretanto, não seria o princípio da beneficência isoladamente suficiente, sendo necessário recorrer também ao de não-maleficência, pois privar um participante de pesquisa de uma droga que está fazendo efeito benéfico, equivaleria a causar-lhe dano (144). Finalmente, porém, enfraquecem a possibilidade de o fornecimento da droga pósestudo ser um dever, dando a entender que tudo se resolve com um bom termo de consentimento, que pode esclarecer ao participante as condições para o fornecimento pós-estudo, que podem ser restritivas, desde que isso seja explicitado.(145)

\subsubsection{Beneficência e paternalismo}

Beauchamp e Childress definem paternalismo como

a desconsideração intencional das preferências ou ações de alguém por outrem, sendo que aquele que o faz, justifica suas ações com um apelo ao objetivo de beneficiar ou evitar ou mitigar danos à pessoa cujas preferências estão sendo desconsideradas. (146)

A relação médico-paciente foi tradicionalmente paternalista, e a justificativa invocada eram os princípios de não-maleficência e beneficência. Algo que ainda acontece, embora em menor escala.

Haveria dois tipos de paternalismo, o "mole" e o "duro". O que os diferencia é a capacidade de exercitar a autonomia do indivíduo cujas preferências estão sendo desconsideradas. Seria o caso no tipo mole, por exemplo, de alguém profundamente deprimido ou afetado por algum vício incapacitante. O paternalismo duro, para 
acontecer, pressupõe que a pessoa tenha plena capacidade de tomar decisões, que serão desconsideradas quer por omissão de informação, quer por ativamente contrariadas. Uma situação que se encaixaria no tipo duro seria, por exemplo, alguém que esteja plenamente consciente e capaz de tomar uma decisão e decide sair de um hospital, mas que se o fizer corre risco de morrer, e a equipe médica se recusa a liberá-la.

Posto dessa forma, tem-se a impressão de que o paternalismo mole seja menos problemático do que o paternalismo duro. Entretanto, aquele tem uma dificuldade que este não tem, a saber, a decisão sobre o quão autônoma uma pessoa está.

O paternalismo pode estar presente também em situações de saúde pública. Exemplos seriam a obrigatoriedade de receita para alguns medicamentos, e as vacinações. Ambos questionados por alguns por privarem os cidadãos de livre escolha, ou seja, sua autonomia. Outro bom exemplo são as campanhas contra tabagismo. Nesse caso, alertam Beauchamp e Childress, corre-se o risco de estigmatização e discriminação, pelo fenômeno de a pecha negativa transferir-se do ato (tabagismo) para a pessoa (tabagista).

Os autores propõem cinco condições que justificariam o paternalismo duro:

1- Um paciente está sob risco de dano significativo e evitável. 2- A ação paternalista provavelmente evitará 0 dano. 3- A prevenção do dano sobrepuja os riscos ao paciente da ação realizada. 4- Não há alternativa moralmente mais adequada à proposta limitação de autonomia. 5- A ação menos restritiva da autonomia que assegura o benefício almejado é adotada. (147)

Uma sexta condição seria a de não ferir interesses autônomos substanciais, como seria o caso de transfundir sangue em Testemunhas de Jeová. Entretanto, como na prática, se o dano potencial for muito grande a tendência é que se fira, sim, preferências profundas de autonomia, uma tal sexta regra não se sustentaria, acreditam os autores.

Uma outra modalidade de paternalismo também pode acontecer, e é menos problemática, acreditam Beauchamp e Childress. Trata-se do paternalismo passivo, quando o profissional de saúde se recusa a realizar algum ato solicitado pelo paciente por acreditar que causará mais mal do que bem, ou ainda por objeção de 
consciência. No caso desta última, os autores não consideram a possibilidade de quem se recusa a realizar algum ato ser a única pessoa em condições de o realizar. Em tal circunstância, a objeção de consciência é, sim, bastante problemática e questionável.

Não realizar uma ação por ter evidências que suportem a crença de que causará mais mal do que bem será o caso, por exemplo, de não tomar medidas fúteis de prolongamento de vida. Nesses casos, porém, os autores recomendam, acertadamente, que se evite o termo "fúteis", trocando-o por "intervenções clinicamente não benéficas". (148)

\subsubsection{Beneficência versus autonomia delegada}

Assim como o princípio de beneficência pode entrar em conflito com o da autonomia em casos em que esta pode ser plena ou incompletamente exercida, também há os casos em que ela não tem como ser exercida pelo próprio agente. Nestes casos, levar-se-á em consideração a autonomia delegada, que pode ser mais ou menos problemática. Será menos problemática quando um paciente deixou sua vontade explícita em documento escrito, e nesse caso o princípio da beneficência será sobrepujado pelo do respeito à autonomia mais facilmente. Já quando não há como acessar a vontade de um paciente a não ser por meio de uma pessoa que lhe é mais próxima, configura-se uma situação mais difícil. A pergunta a ser feita é "O que o paciente quereria em tal situação?", e não "O que você quer para seu pai (filho, amigo)?" (149). Se não há segurança quanto ao desejo do paciente, o princípio de beneficência deve prevalecer.

\subsubsection{Benefício versus custo}

As análises de custo $\mathrm{x}$ benefício, típicas das tomadas de decisão em saúde pública têm a desvantagem de monetarizar vidas humanas. O princípio de beneficência nestes casos precisa prevalecer sobre contas de quanto custa para se alcançar o benefício almejado, se vale ou não o gasto. Uma das análises possíveis e aceitáveis, a depender das circunstâncias, é a que configura o benefício não apenas 
em termos quantitativos, mas principalmente qualitativos - os QALY quality-adjusted life years - anos de vida ajustados por qualidade. Ao considerar não simplesmente quanto mais o sujeito viverá, mas a qualidade desse tempo de vida, os QALY refletiriam melhor a intenção do princípio de beneficência em situações de saúde pública. Entretanto, Beauchamp e Childress reconhecem, permanece o problema do que vem a ser adequadamente interpretado como "qualidade de vida". Outra questão é que os QALY teriam como base filosófica o utilitarismo, herdando dele também os problemas, notadamente o risco de se deixar de fora parcela importante, que mereceria ser igualmente considerada (por exemplo, privilegiando jovens em detrimento de mais velhos). (140)

\subsection{Não-maleficência}

O ponto de partida para o princípio de não-maleficência seria a máxima "Acima de tudo, não faça mal (não cause dano)". Que pode ser reescrito desta forma: "Não se deve infligir mal ou dano". Beauchamp e Childress não consideram normas que podem ser derivadas deste princípio como sendo de não-maleficência. Estas seriam: 1- Deve-se prevenir o mal ou o dano. 2- Deve-se remover o mal ou o dano. 3- Deve-se fazer ou promover o bem. Tais normas, consideradas por alguns autores como abarcadas pelo princípio de não-maleficência, seriam, na concepção de Beauchamp e Childress, pertencentes ao campo do princípio da beneficência. (151)

Nesse momento os autores acenam para a direção que tomarão, pois afirmam que o princípio de não-maleficência "tipicamente sobrepuja os demais" (151), para, em seguida, restringi-lo ao mínimo. Prevenir dano, remover dano e fazer o bem requerem uma tomada de posição ativa por parte do sujeito moral, algo que os autores não estão dispostos a considerar um dever. Louvável, portanto, um ideal, mas não um dever. As regras de não-maleficência terão a forma "Não faça X". (151)

Um primeiro conceito a ser clareado é o de dano. Nem tudo o que à primeira vista é dano de fato o será, uma vez pesadas as consequências. Um exemplo clássico é dado por Beauchamp e Childress - amputação de um membro. A perda de um membro é algo sempre indesejável, mas, se o tiver de ser para evitar um mal 
maior (gangrena, por exemplo), não será propriamente um dano. Ou, pelo menos, um "dano" aceitável em vista da alternativa pior.

O princípio de não - maleficência abarca algumas regras para sua especificação, tais como: 1- Não mate. 2- Não cause dor ou sofrimento. 3- Não cause incapacidade. 4- Não cause ofensa. 5- Não prive os outros dos bens da vida. (152)

\subsubsection{Negligência}

Não sendo Principles of Biomedical Ethics um livro de bioética, mas, sim, de ética biomédica, seus autores concentram-se nas possibilidades de danos físicos, e, entre estes, particularmente a morte em circunstâncias de serviços de saúde.

De acordo com Beauchamp e Childress, há duas possibilidades de negligência, intencional e não intencional (153). Quando um profissional de saúde deixa deliberadamente de realizar um ato que faz parte dos cuidados de um paciente, está sendo intencionalmente negligente. Será não intencional mais o caso de uma desatenção, em que o profissional sabe o que tem de fazer, mas deixa de fazê-lo não deliberadamente, por esquecimento, entre outros motivos possíveis.

Os autores propõem uma espécie de "check list" para que se configure negligência: 1- $O$ profissional tem deveres em relação à parte afetada. 2- $O$ profissional deve descumprir tais deveres. 3- A parte afetada sofreu algum dano e 4este dano foi em decorrência do dever não cumprido.

\subsubsection{Não-maleficência e ética em pesquisa}

Ética em pesquisa é pouco explorada em Principles of Biomedical Ethics. O capítulo de não-maleficência refere-se a "subproteção" e "sobreproteção". Os autores reconhecem que "historicamente, os riscos de danos a sujeitos de pesquisa têm sido colocados majoritariamente nos mais vulneráveis, mais doentes e economicamente desprotegidos, dada a sua pronta disponibilidade" (154). Reconhecem ainda a necessidade de proteção aos mais vulneráveis contra a 
possibilidade de exploração utilitarista. Entretanto, em seguida ponderam que tais preocupações podem criar atrasos importantes no progresso das pesquisas, o que caracterizaria uma "sobreproteção".

O caso citado pelos autores para dar suporte à sua ponderação acerca de "sobreproteção" é o de uma pesquisa de diagnóstico de eficácia de medidas preventivas de infecção em unidades de cuidados intensivos. Embora, da forma como apresentado, pareça de fato ter se tratado de um exagero por parte da comissão de ética no nível nacional (cuja interpretação inicial foi diferente da do CEP local), há dois problemas com este exemplo. Primeiro, a justificativa dos autores é inadequada: "Mas esta pesquisa tinha, em seu desenho, uma tentativa de melhorar os cuidados médicos" (155). Ora, que pesquisa na área biomédica não tem este mesmo objetivo? E segundo, e mais importante, os autores contentam-se apenas com este exemplo para concluir que o problema de "sobreproteção" merece mais nossa atenção do que o da "subproteção", o que certamente não é o caso.

\subsubsection{Deixar de fazer e retirar (interromper) tratamento}

A distinção entre não iniciar um tratamento e interrompê-lo tem implicações importantes na maneira como as pessoas julgam moralmente o ato. Há uma facilidade maior em aceitar que um tratamento não seja iniciado, do que, uma vez iniciado, que seja interrompido (156). Isso diz respeito principalmente a tratamentos que mantenham um paciente vivo, em situações nas quais as chances de sucesso são mínimas ou mesmo nulas. Um risco que tal situação traz é tanto de "sobretratamento" quanto de "subtratamento". A primeira situação seria a de se ter iniciado uma intervenção que se revela fútil e não se tenha a coragem de interrompê-la. Mas pode também ser o caso da segunda, que é justamente o receio de se entrar numa situação de "sobretratamento", de difícil saída, nem se dar chance (considerando-se que há chance). Os autores concluem que esta distinção entre não iniciar e interromper mais atrapalha do que ajuda, e a decisão deve-se basear em outros critérios, que não esta distinção. 


\subsubsection{A regra (doutrina, princípio, teoria) do duplo efeito}

O duplo efeito caracteriza-se por uma ação que tem ao mesmo tempo um efeito bom e um ruim. Para que tal ação seja considerada moralmente aceitável, mesmo com o efeito ruim, são necessárias algumas condições, tais como a natureza do ato, a intenção do agente, a distinção entre meios e efeitos e a proporcionalidade entre o efeito bom e o ruim (157). Beauchamp e Childress, acertadamente, ponderam que todas estas condições são problemáticas, o que torna o julgamento de um ato (se moralmente correto ou não) pela doutrina do duplo efeito, consequentemente, problemática.

Assim como Alan Donagan (158), Beauchamp e Childress avaliam que o peso dado à intenção é equivocado. Diferenciar intenção de previsão é muitas vezes difícil, e, mais ainda, inútil. O caso do aborto é emblemático. Os autores elencam quatro possibilidades: 1 - Câncer cervical da mulher grávida cuja cura requer histerectomia que matará o feto. 2- Gravidez ectópica, cujo tratamento resultará na morte de um feto de toda forma inviável. 3- A mãe tem uma cardiopatia grave, com grande chance de morrer se levar a gravidez até o fim. 4- Trabalho de parto complicado, com grande risco de morte para a mãe caso uma craniotomia não seja realizada no feto, levando à sua morte. As duas primeiras situações poderiam ser toleradas pela doutrina católica, pois preencheriam os requisitos de ser 0 ato (histerectomia e correção cirúrgica da gravidez ectópica) moralmente não condenável, a intenção do agente não é a morte do feto, o efeito não é o meio para se alcançar o objetivo e o objetivo é suficientemente nobre em contraposição ao efeito ruim.

Beauchamp e Childress ponderam que não faz muito sentido distinguir a morte de um feto como consequência de uma histerectomia ou de uma craniotomia (159). Ainda que se aceite a distinção de que na primeira trata-se de um efeito ruim previsto, mas não pretendido, e na segunda, previsto e pretendido, a consequência é a mesma. Os autores rejeitam, portanto, a regra do duplo efeito como especificação satisfatória do princípio de não-maleficência, particularmente no caso do aborto. Mas não oferecem uma saída. Afinal, matamos o feto ou a mãe? Interessante notar que a moralidade comum não é sequer lembrada aqui, diferentemente do que fez Donagan, que a usou para fundamentar a ponderação de 
que não faz sentido separar o ato em intenção e efeito, pois, para a moralidade comum, são uma coisa só, indissociável (160). Matar um inocente para salvar outro inocente é tido como moralmente condenável de forma geral, sê-lo-á também no caso do aborto. Conclusão a que chega também a filósofa Philipa Foot no clássico artigo The problem of abortion and the doctrine of the double effect (161), embora com a ressalva de que possivelmente as pessoas mudariam de ideia se se tratasse de matar um inocente para salvar vários.

A regra do duplo efeito teria mais chance de funcionar em casos de pacientes moribundos. Um médico que fornecesse medicação forte para aliviar dor e sofrimento poderia prever, mas não pretender a morte do paciente que desejasse pôr fim a este sofrimento com a própria morte. De toda forma permanece a dificuldade da tênue fronteira entre o que é meramente previsto e o que é pretendido. (162)

\subsubsection{Matar e deixar morrer}

Outra distinção nem sempre fácil de se estabelecer é entre matar e deixar morrer. Vulgarmente, matar envolveria um ato intencional e causal para que a morte aconteça, enquanto deixar morrer envolve também intenção, mas não ativamente, mas, sim, passivamente (deixar de fazer algo). Beauchamp e Childress acreditam que esta distinção não chega a ser satisfatória. (163)

A próxima dificuldade é atrelar julgamentos morais a uma e outra possibilidade. Deixar morrer será aceitável, defendem os autores, sob uma de duas condições: 1- A tecnologia médica é inútil para o caso em questão. 2- O paciente (ou seu responsável autorizado) recusa uma tecnologia médica. Se nenhuma destas duas condições está presente, não será o caso de deixar morrer, mas, sim, de matar, portanto moralmente condenável.

A posição assumida pelos autores é que deixar morrer, pela perspectiva da ética biomédica, será aceitável e, mesmo, preferível, se as condições acima forem respeitadas, considerando então como preponderante o respeito à vontade autônoma de um paciente para quem toda tecnologia médica será fútil. Caso o profissional de saúde não se sinta confortável em ceder à vontade do paciente, não 
deverá recusar o acesso a quem possa satisfazê-la (164). Os autores acreditam que, nesses casos, o que está em jogo são, além dos princípios de beneficência e respeito à autonomia, também as virtudes da compaixão e do cuidado. (165)

\subsubsection{Dano à coletividade}

Fugindo um pouco do traçado de sua obra, Beauchamp e Childress abordam rapidamente a possibilidade de dano à coletividade, mas apenas no contexto de uma pesquisa. Para tanto, citam o caso dos índios Havasupai (166). A partir de uma intenção inicial de investigar a alta prevalência de diabetes neste grupo, pesquisadores valeram-se de um consentimento amplo para se debruçar sobre vários outros aspectos, completamente diferentes, como por exemplo esquizofrenia, e até sua origem geográfica. Neste último caso, o estabelecimento da hipótese de que eles não eram originários da região em que viviam (Grand Canyon), mas, sim, da Ásia, tinha até implicações legais, pois sua origem, além de importância religiosa, era a base de sua alegação de direito de posse da terra onde viviam. A maleficência, nesse caso, foi claramente coletiva, social, ainda que no contexto de uma pesquisa.

\subsection{Justiça}

Beauchamp e Childress iniciam o capítulo sobre o princípio da justiça admitindo que "nenhum princípio moral isoladamente é capaz de dar conta de todos os problemas de justiça". E ainda: "Neste capítulo discutiremos vários princípios e consideraremos como eles podem ser balanceados e especificados em contextos de cuidados de saúde e saúde pública" (167). É emblemática a escolha dos autores, no sentido de dar razão à crítica de Clouser e Gert (1990). E problemática no sentido de não apenas não se decidirem por uma das teorias de justiça, como, principalmente, não fazerem referência uma única vez à sua própria teoria pretensamente unificadora - a moralidade comum.

Uma primeira abordagem à justiça seria o princípio formal atribuído a Aristóteles que determinaria que iguais sejam tratados igualmente, e diferentes, diferentemente (167). Tal princípio seria por demais abstrato, carecendo de 
substância, e, portanto, carecendo de especificações concretas.

Uma primeira especificação possível seria a da distribuição ponderada pela necessidade. Por necessidade deve-se entender necessidade básica, sem a qual há dano para a integridade do sujeito. Embora se trate de uma especificação aparentemente óbvia, os autores ponderam que não será unanimemente aceita, pois dependerá da perspectiva a partir da qual será analisada.

Seriam seis, de acordo com Beauchamp e Childress, as perspectivas possíveis, originadas em quatro teorias tradicionais de justiça e mais duas que seriam recentes. Cada teoria articula um princípio geral material para a justiça distributiva (168):

1- Para cada pessoa de acordo com regras que maximizem a utilidade social (utilitarismo). 2- Para cada um o máximo de liberdade e propriedade resultante do exercício dos direitos de liberdade e participação em trocas justas de livre-mercado (libertária). 3- Para cada um de acordo com princípios de distribuição justa derivados de concepções do bem desenvolvidas em comunidade morais (comunitária). 4- Para cada um uma medida igual de liberdade e acesso igual aos bens na vida que cada pessoa racional valoriza (igualitária). 5- Para cada um os meios necessários para o exercício das capacidades essenciais para uma vida produtiva (de capacidades). 6- Para cada um os meios necessários para a realização de dimensões essenciais de bem-estar (de bem-estar).

Embora não haja impedimentos a que se use mais de uma ou mesmo todas as teorias de justiça acima apresentadas, não raramente elas competem entre si, ponderam os autores, o que faz com que seja necessário um procedimento similar ao proposto aos próprios princípios bioéticos proposto pelos autores, uma hierarquização circunstancial prima facie.

Após avaliar cada uma das teorias citadas, Beauchamp e Childress concluem que cada uma é apenas parcialmente adequada como proposta de princípio de justiça na concepção de justiça social. Mas os autores se declaram mais propensos à utilização do igualitarismo, no que diga respeito à distribuição de cuidados de saúde e recursos em saúde pública. (169)

\subsubsection{Oportunidades iguais, discriminação injusta}

O ponto de partida escolhido por Beauchamp e Childress é a teoria da justiça 
de Rawls. O que é coerente com a citação da abertura do capítulo, a "A loteria em Babilônia", do escritor Jorge Luís Borges. Categorias que tradicionalmente serviram como distribuidoras automáticas de benefícios, tais como gênero, raça, QI, sotaque, etnicidade, nacionalidade e classe social, são produto de uma loteria e, portanto, inadequados como norteadores de uma distribuição justa.

A regra que estabelece oportunidades iguais, com origem na teoria rawlsiana, corrigiria distorções tais como pessoas com deficiências funcionais não terem oportunidade iguais na vida por causa dessas deficiências. (170)

Beauchamp e Childress acenam para uma concordância com Rawls, acompanhando-o na linha de raciocínio de que não apenas loterias biológicas sejam injustas, mas também as sociais. Mas rapidamente o abandonam por considerar que a consequência prática disso seria "exigente demais". Nesse momento valem-se da teoria libertária que aponta que os recursos limitados impõem limites à aplicação da regra rawlsiana, mas discordam da posição libertária quanto a diferenciação entre o que seja apenas um infortúnio, e o que seja de fato injusto. (171)

Não pode ser creditado apenas a "infortúnio", por exemplo, que classes menos favorecidas da sociedade norte-americana tenham menos acesso a "produtos" de cuidados em saúde e estejam mais submetidos a riscos por participação em pesquisas. Não deve passar despercebido que nesta passagem, como em várias outras deste capítulo, os autores utilizem o termo "produtos" (goods) para se referir aos cuidados de saúde (171). Trata-se de um detalhe que merece atenção. Embora os autores eventualmente se valham do vocabulário de direitos humanos, fica evidente a perspectiva a partir da qual enfrentam o problema da justiça em saúde. Sendo esta uma mercadoria, e não um direito, será a abordagem de livre-mercado que acaba prevalecendo, a despeito das tentativas dos autores de conciliação com as demais teorias de justiça. O que até é coerente com sua teoria da moralidade comum, se por 'moralidade comum' se entender 'moralidade do senso comum norte-americano'. 


\subsubsection{Justiça em pesquisa}

Os autores abordam dois problemas que identificam como sendo importantes no que diga respeito à justiça em pesquisa científica em saúde. A indução indevida e - lucro indevido. A primeira equivaleria a induzir (em tese, involuntariamente) indevidamente pessoas em situação economicamente desfavorável por meio de um pagamento que as façam participar sendo que, em situações normais não o fariam, o que tem implicações no risco a que se propõem a se submeter. Por outro lado, esse pagamento não pode ser de tal forma pequeno, cuja consequência seria o oposto, um lucro indevido por parte da indústria farmacêutica. Entretanto, os próprios autores reconhecem, "lucro indevido" é algo intrínseco à atividade da indústria farmacêutica. Uma das possibilidades de correção dessa distorção seria a regra (que o Brasil já adota) de disponibilizar os benefícios da pesquisa para os participantes desta enquanto eles necessitarem, mesmo após o término da pesquisa. Beauchamp e Childress mencionam tal possibilidade no capítulo do princípio de beneficência, até de forma positiva, mas não assertiva. Não chegam à conclusão de que seja um dever moral. (144 e 145)

Por fim, a posição dos autores quanto à possibilidade de exploração de países pobres por parte da indústria farmacêutica é questionável, para dizer o mínimo. Sendo a participação dos cidadãos desses países uma sua fonte de renda importante, estaria justificado que a indústria faça pesquisas nesses países, pagando pela participação. De acordo com Beauchamp e Childress seria paternalista e nocivo negar esta oportunidade de renda a esta população. (172) 


\subsubsection{Política Nacional de Saúde}

Dois argumentos principais dariam suporte a um sistema de saúde financiado pelo governo - uma proteção social coletiva e igualdade de oportunidade.

A proteção social coletiva encontra, nos EUA, a resistência de muitos, notadamente libertários, que não consideram obrigação do governo prover saúde (ou qualquer coisa). Uma saída seria o princípio da reciprocidade. Como a sociedade coletivamente contribuiu para a formação de profissionais de saúde e a realização de pesquisas biomédicas, os profissionais de tais áreas deveriam devolver o que receberam em bens e serviços. Tal proposta não seria consistente nem suficiente. $O$ argumento da igualdade de oportunidades se sustentaria pelo menos no que dissesse respeito a deficiências biológicas, pois, nesse caso, desvantagens acontecem e têm como consequência um desequilíbrio de oportunidades na vida. (173)

Beauchamp e Childress declaram-se dispostos a defender pelo menos um objetivo igualitário, ainda que moderadamente igualitário, que seria o "mínimo decente" de cuidados em saúde. Mas o que seria esse "mínimo decente". A concepção-padrão seria composta de duas partes, sendo a primeira uma cobertura social compulsória para casos básicos e catastróficos, e a segunda uma cobertura voluntária para outras necessidades e desejos. Os autores acreditam que dessa forma conseguem uma rede de proteção social satisfatória que, ao mesmo tempo, admite não ser ilimitada. Tal concepção de um "mínimo decente" teria a virtude de conseguir conciliar as diversas teorias de justiça, já que uma única proposta de teoria de justiça é pouco provável de ser alcançada, acreditam eles.

O problema com o "mínimo decente", todavia, não tarda a aparecer, e é mesmo óbvio. O que é o "mínimo" de que se fala aqui? O que podem ser consideradas necessidades minimamente básicas, notadamente numa nação em que o ponto de partida é a saúde como produto, numa situação de livre mercado? Considerando que as leis de mercado determinam o valor de um produto, entre outras coisas, pela demanda, quanto mais básico, mais se necessita e, portanto, mais valioso. Acrescente-se a isso a possibilidade de uma necessidade básica de saúde estar relacionada a hábitos de vida que propiciaram que tal necessidade 
ocorra. Medicações anti-virais para indivíduos que contraíram AIDS por terem praticado sexo inseguro ou usado drogas sem cuidado, tratamento para alcoólatras, de câncer para fumantes e assim por diante (174). Beauchamp e Childress admitem a possibilidade de que seria justo cobrar-se mais dos seguros-saúde ou cobrar impostos de pessoas que deliberadamente assumem hábitos de vida mais arriscados.

Quando se referem às políticas de saúde global, Beauchamp e Childress até assumem uma posição interessante, reconhecendo a importância e mesmo acenando com um tratamento prioritário a países mais pobres: "Se o alcance da justiça social é global, esse tipo de iniquidade a partir de condições de desvantagem estaria no topo da lista de condições a serem remediadas" (175). Lembram ainda que não se trata apenas de saúde no sentido estrito, mas, sim, amplo, incluindo aí determinantes sociais de saúde. Entretanto, não chegam a propor algo de concreto nesse sentido.

\subsubsection{Alocando, priorizando e racionando recursos}

A alocação de recursos para a saúde ocorrerá a partir do orçamento geral. Este primeiro momento deve ser suficiente para o "mínimo decente". Uma vez separados os recursos para a saúde, deve se proceder à alocação entre as diferentes situações em saúde, levando-se sempre em consideração que não existe somente medicina terapêutica, mas também preventiva e proteção ambiental, auxílio à pobreza, enfim, levando em consideração que os recursos gerais, uma vez alocados à saúde, não se deve esquecer dos determinantes sociais de saúde. $\mathrm{O}$ próximo passo é, dentro de cada categoria destinar para diferentes focos de atenção. Finalmente, lidar com os recursos escassos, já que as demandas podem ser ilimitadas. (176)

Estabelecer prioridades é sabidamente difícil, e os autores citam um caso concreto de tentativa nesse sentido, ocorrido no estado do Oregon, que teve como resultado algumas distorções bizarras. Por exemplo, em seu sistema de prioridades, tratamento dentário menor estaria acima de uma apendicectomia. Propõem, então, algumas estratégias para estabelecer prioridades em saúde. Uma primeira seria a 
utilitarista, seriam prioridades as ações em saúde que alcançassem o maior benefício com o menor custo. Bastante justa e racional à primeira vista, também pode provocar distorções, discriminando contra grupos mais vulneráveis que, mesmo precisando mais, não pontuariam bem numa tabela de custo/benefício. Outra possibilidade seria a que levaria em conta a opinião de algumas pessoas ao estabelecer as prioridades, por exemplo, a opinião pública. Tal abordagem carrega em si o perigo de a opinião se formar por vias completamente estranhas às que realmente importam à questão posta. Beauchamp e Childress não se decidem por uma abordagem para resolver o dilema da priorização.

Ao tratar do racionamento de recursos, os autores lembram: "Numa economia de mercado, todos os tipos de mercadorias - incluindo cuidados em saúde - são em certa medida racionados pela capacidade de pagar" (177). Duas abordagens seriam possíveis para a tomada de decisão em situação de racionamento de tratamentos escassos para pacientes. De novo, a utilitária, e a igualitária. Os autores acreditam que estas podem ser combinadas. Por outro lado, em sua conclusão final ao capítulo, admitem que eficiência (utilidade) e justiça (igualitarismo) geralmente entram em conflito. "Inevitavelmente, negociações entre equidade e eficiência ocorrerão". 


\subsection{RESPEITO À AUTONOMIA}

\subsubsection{Sobre autonomia}

Beauchamp e Childress abrem o capítulo dedicado ao princípio do respeito à autonomia abordando as críticas que lhe são dirigidas particularmente quanto a este princípio. Os autores acreditam que "o respeito às decisões autônomas das pessoas está tão profundamente enraizado na moralidade comum como qualquer outro", mas "não tem sempre prioridade sobre todas as outras considerações morais" (178). Interessante e reveladora a escolha de palavras aqui - sempre. Dá a entender que tem, de forma geral, prioridade, mas não sempre. Outro ponto reforçado pelos autores é de que tratam da autonomia no contexto biomédico, e não bioético. Interessa a eles apenas a autonomia de pacientes e participantes de pesquisa.

Seriam três as condições que necessitam ser preenchidas para que um ato seja considerado fruto de um sujeito autônomo: 1- Intencionalidade. 2Compreensão. 3- Controle (não-coerção) (179). A intencionalidade não elimina a possibilidade de ocorrência de um resultado indesejável. Ter a intenção de fazer algo pode incluir prever meios desagradáveis ou mesmo resultados indesejados (como a discussão da regra duplo efeito, no princípio de não-maleficência, demonstra). Por sua vez, a compreensão não implica, necessariamente, compreensão absoluta e completa de algo. Coerentes com sua proposta de uma autonomia "real" e não "ideal", os autores acreditam que seja possível ser autônomo sem compreensão total, desde que esta seja suficiente para proporcionar subsídios ao sujeito. Dificuldades cognitivas, problemas na comunicação, imaturidade podem comprometer a compreensão substancialmente e, consequentemente, a autonomia. Quanto ao controle, diz respeito ao autocontrole, a ausência de pressões, sejam externas ou internas (este seria o caso em algumas doenças).

Embora a primeira das condições - intencionalidade - não tenha espaço para gradações (ou um ato é intencional, ou não é), as duas seguintes têm. Tanto a compreensão quanto a coerção podem sem mais ou menos significativas. Em linguagem estatística, a intencionalidade seria uma variável nominal, enquanto compreensão e controle, variáveis contínuas. A consequência disto é que o próprio 
conceito de autonomia equivaleria a uma variável contínua, e é preciso estabelecer um ponto a partir do qual classifica-se uma ação como autônoma ou não-autônoma.

O próximo ponto abordado pelos autores diz respeito ao conceito de 'autoridade' em sua relação com a autonomia. Não é todo tipo de autoridade que será coercitivo. Por exemplo, a autoridade religiosa não o será se o sujeito a tiver abraçado espontaneamente. Assim também o caso da autoridade médica, em que o sujeito se submete ao que se lhe é prescrito. Nesse sentido vale lembrar uma diferença da qual os autores não lançam mão. Hans-Georg Gadamer chama de autoritário aquele que exerce sua autoridade de forma impositiva, e de autoritativo aquele que a exerce de forma humilde, abrindo espaço para a possibilidade de crítica (180) autoritativa seria o caso de uma relação plenamente (ou pelo menos satisfatoriamente) autônoma, enquanto autoritária, não.

\subsubsection{O princípio do respeito à autonomia}

O princípio do respeito à autonomia comportaria duas modalidades, sendo uma negativa (fraca) e outro positiva (forte). A negativa seria mais fraca pois requereria do agente moral apenas que não interferisse na decisão do paciente moral. Já a positiva é mais exigente, já que um dos requisitos para o exercício da plena autonomia está em direta correlação com a compreensão do paciente moral, por sua vez relacionado com o acesso à informação. É dever do agente, então, prover o paciente de toda informação pertinente à possibilidade de uma decisão autônoma, portanto, uma posição ativa, mais forte do que simplesmente não interferir. De fato, o que acontece é mesmo uma interferência, mas positiva, necessária à compreensão do paciente.

Como todo princípio, defendem Beachamp e Childress, também o do respeito à autonomia precisa de ser especificado por meio de regras morais práticas. Estas seriam, por exemplo: 1- Diga a verdade. 2- Respeite a privacidade dos outros. 3Proteja informações confidenciais. 4- Obtenha consentimento para intervenções. 5Quando instado, ajude outros a chegar a suas decisões.

Sendo a preponderância de cada princípio apenas prima facie, também o será o do respeito à autonomia. Entretanto, novamente aqui a escolha de palavras não 
deixa de ser intrigante e de certa forma reveladora: "considerações morais concorrentes às vezes se sobrepõem a este princípio" (181). Cabe a pergunta: Se outras considerações morais somente "às vezes" preponderam sobre o princípio de respeito à autonomia, então é a regra que este prevaleça?

Algumas de tais situações são enumeradas pelos autores. Seriam os casos de colocar em perigo a saúde pública, demandar recursos escassos, ou ainda pôr em risco pessoas inocentes, por exemplo. Outras situações seriam exemplos de impossibilidade de exercício de autonomia, como em pessoas imaturas, mentalmente incapacitadas, etc. Mas nestes casos os autores alertam que não se trata de despeitar tais pessoas, mas, sim, de protege-las por não terem como exercer elas próprias sua autonomia.

Uma crítica que se faz ao princípio do respeito à autonomia é rebatida por Beauchamp e Childress. Citando dois estudos realizados em pessoas de culturas diferentes, que demonstraram (um deles) que americanos de origem coreana e mexicana, e (o outro) que índios navajos tinham uma percepção de autonomia bastante diferente do americano de origem europeia ou africana, os autores discordam da conclusão dos estudos, que seria negativa à abordagem principialista. O fato de pessoas delegarem a decisão a outros e não desejarem eles próprios terem acesso a informações a respeito de sua saúde, ponderam Beauchamp e Childress seria, por si só, uma manifestação de sua autonomia. (182)

\subsubsection{Consentimento}

Consentimento é elemento chave ao respeito à autonomia. Beauchamp e Childress reconhecem possibilidades diferentes para sua obtenção em contexto de cuidados de saúde. Idealmente, será explícito, fruto de um exercício pleno, bem informado, da autonomia. Mas há situações em que pode ser implícito, inferido. Tais situações, entretanto, facilmente se configuram bastante questionáveis. Como no caso de um consentimento presumido por parte de pacientes que dão entrada em hospitais-escola, particularmente se em situação bastante vulnerável, como quando se encontram anestesiados.

Uma outra forma de consentimento presumido e também por isso 
problemática, seria a que pode ser encontrada em situações de saúde pública. A política de se inverter a opção no caso de doação de órgãos, por exemplo. Em vez de exigir que os doadores manifestem seu desejo, exigir que os não-doadores manifestem sua recusa. Por trás dessa estratégia, além da consideração de beneficência aos receptores sem maleficência aos doadores, está o fato de se contar com a inércia. Nos EUA não é assim e Beauchamp e Childress perguntam-se como se daria se assim fosse (183), alertando que uma tal medida teria de vir acompanhada de uma vigorosa campanha de informação. A recente e malfadada experiência do Brasil lhes dá razão.

O consentimento será sempre do paciente ou participante de pesquisa. Beauchamp e Childress rechaçam as abordagens que propõem um "consentimento compartilhado", pois abre a possibilidade de um retorno ao paternalismo nas relações entre profissional de saúde (ou de pesquisa) e o paciente (ou participante). Para que possa ser dado de forma satisfatoriamente autônoma, é necessário que o paciente/participante de pesquisa tenha compreendido, senão completamente, pelo menos substancialmente seu conteúdo (se formal) ou a circunstância (se informal). Para tanto, é necessária a disponibilização efetiva das informações pertinentes. A realização de procedimentos médicos ou pesquisas biomédicas sem a obtenção de um satisfatório consentimento, obtido a partir da disponibilização efetiva das informações não será, na maioria das vezes, moralmente aceitável.

É interessante notar que Beauchamp e Childress, ao tratarem das diferentes formas de justificação para disponibilizar (ou não) informações, fazem considerações que podem ser consideradas como pertinentes à própria teoria da moralidade comum. De acordo com eles, duas dessas formas, os padrões de prática profissional, e o padrão da pessoa razoável possuem grandes dificuldades para serem adotadas. A primeira, por que "é incerto que em muitas situações haja de fato um padrão costumeiro para a comunicação em medicina" (184). A segunda, pela dificuldade de se definir o que seja uma "pessoa razoável". Ora, se moralidade comum se refere a "normas sobre o certo e o errado amplamente compartilhadas" (132), ou seja, se é certo e errado aquilo com que estamos acostumados, e se tais normas são compartilhadas "por pessoas moralmente comprometidas" (132), portanto razoáveis, não seria despropositado concluir que os próprios autores estão fornecendo aqui elementos críticos à sua fundamentação na moralidade comum. 


\section{CRÍTICAS À MORALIDADE COMUM}

Se a importância de uma obra for medida pelo volume de críticas que recebe, certamente Principles of Biomedical Ethics tem grande valor, como bem lembrou DeGrazia (185). O que não deixa de ser verdade. De maneira geral, os críticos à proposta principialista de Beauchamp e Childress sempre fazem a ressalva quanto ao inegável papel essencial que sua obra ocupa na construção de uma epistemologia bioética. E é justamente por ocupar tal posição que suas eventuais deficiências ganham destaque.

Há basicamente duas perspectivas a partir das quais partem as críticas ao Principialismo e à moralidade comum. Autores com origem em países ricos têm como alvo principal a fundamentação filosófica, enquanto os autores com origem em países periféricos têm seu alvo principal na consequência prática da proposta de Beauchamp e Childress. O que não significa que as perspectivas não se entrecruzem. Se a fundamentação filosófica é falha, as consequências práticas serão ilegítimas, ao mesmo tempo em que não há como se preocupar com as consequências práticas sem se analisar a fundamentação teórica. Não se trata de abordagens críticas mutuamente excludentes, portanto, mas, frequentemente, complementares.

Outro aspecto a ser considerado é que nem sempre as críticas são direcionadas à fundamentação teórica do Principialismo - a teoria da moralidade comum de Beauchamp e Childress - mas, sim, ao Principialismo como proposta para uma ética aplicada às situações biomédicas. Este foi o caso das primeiras críticas mais contundentes, justamente por não haver uma proposta estruturada de fundamentação nas primeiras edições de Principles of Biomedical Ethics.

Talvez a mais importante entre as críticas iniciais seja a de Clouser e Gert (186), que servem como um divisor de águas para a trajetória da obra de Beauchamp e Childress, motivando-os a construir e estruturar sua própria fundamentação. 


\subsection{Principialismo}

Clouser e Gert (186) criticam o Principialismo a partir de duas perspectivas, a de William Frankena, tal como exposta em sua obra Ethics, e a de Beauchamp e Childress, tal como exposta na segunda edição de Principles of Biomedical Ethics, que é de 1983. Logo antes de terem publicado sua crítica, saiu a terceira edição de Principles of Biomedical Ethics, em 1989. Em nota ao final do artigo, Clouser e Gert justificam ter mantido sua crítica direcionada à segunda edição para enfatizar sua posição de não criticar autores específicos, mas, sim, uma "Gestalt" que acreditam estar presente na abordagem à ética biomédica. (187)

Considerando que o centro da crítica de Clouser e Gert seja a falta de uma teoria ética que dê sustentação aos princípios propostos por Beauchamp e Childress, de fato não faz muita diferença que se use a segunda ou terceira edição, pois foi a partir da quarta edição (1994) que a teoria da moralidade comum foi introduzida, e a partir da quinta edição (2001), que ela surgiu como proposta mais consistente (185)

No que diga respeito à abordagem principialista de Beauchamp e Childress, a crítica de Clouser e Gert concentra-se no fato da inexistência de uma única teoria moral que dê sustentação aos princípios. Do que resultaria uma abordagem "de antologia", abarcando várias diferentes teorias. Desse modo, "a beneficência incorporaria Mill, autonomia, Kant, justiça, Rawls, e não-maleficência, Gert” (188). Isso enfraqueceria bastante a abordagem de Beauchamp e Childress, fazendo com que cada princípio funcionasse mais como um título de capítulo, para onde o leitor se remeteria para discutir determinadas possibilidades direcionadas a determinadas circunstâncias, sem uma unidade entre elas. Não há sequer, seguem argumentando Clouser e Gert, uma tentativa de corrigir as falhas de cada teoria ética apontada na abordagem "de antologia", ou a proposta de uma teoria unificadora (que viria a ser a moralidade comum, mais adiante). A consequência disso, acreditam eles, é um relativismo insatisfatório como fundamentação aos princípios biomédicos. A solução mais adequada seria a adoção de uma teoria moral que incluísse todas as pessoas moralmente comprometidas, cujo melhor exemplo seria justamente a proposta de um deles - Bernard Gert - tal como exposta em Morality: A New Justification of the Moral Rules, de 1988. (189) 
Como ilustração do problema criado pela falta de uma teoria consistente que dê suporte ao Principialismo, os autores citam o caso do princípio de beneficência. Tal princípio explicitamente prescreve que se previna e remova danos, assim como que se confira benefícios (190). Beneficência não tem como ser um dever moral, acreditam eles, porque deveres morais exigem imparcialidade, algo que a beneficência, por natureza, não tem. Como é possível realizar ativamente atos beneficentes para todo mundo? (142). Aqui vale mencionar que Beauchamp e Childress reconhecem tal dificuldade e propõem algumas soluções na última edição (2013) de sua obra. O princípio da justiça também é citado para ilustrar a falta de uma teoria única. De acordo com Clouser e Gert, [o princípio da justiça] é "claramente não um guia para a ação, mas sim uma lista de considerações que deve ser tida em mente quando se reflete sobre problemas morais". (191).

Beauchamp e Childress ocupam-se especificamente das críticas de Clauser e Gert. Criticam, por sua vez a proposta de normas de conduta da proposta de Bernard Gert, por considerarem tais normas pouco específicas, lembrando que os princípios precisam ser contextualizados, especificados e ponderados para serem postos em prática. Com relação ao princípio de beneficência, que Clouser e Gert consideram não um dever, mas um ideal moral, Beauchamp e Childress sustentam que esta tomada de posição vem de uma interpretação equivocada da moralidade comum. E lembram que a própria teoria de Gert prevê a beneficência como dever, se num contexto de dever de profissional da saúde, que é o contexto em que se insere sua proposta (192). Pode-se até considerar razoavelmente satisfatórias tais respostas, mas o mesmo pode ser dito quando Beauchamp e Childress se referem à crítica de não haver uma teoria que fundamente adequadamente seus princípios. Os autores reconhecem que não construíram uma teoria ética fundamentadora. O que provoca o questionamento: o que é então, a moralidade comum?

\subsection{Fragilidades de uma moral intuitiva do senso comum}

Debruçando-se sobre a quinta edição (2001) de Principles of Biomedical Ethics, L. Turner (193) questiona o que considera as três pressuposições recorrentes da teoria bioética contemporânea, particularmente evidentes no principialismo de Beauchamp e Childress (mas também em outros teóricos da moralidade comum). 
Seriam elas a pressuposição de que exista uma moralidade comum universal, transhistórica, que serviria de base normativa para julgar várias ações, que tal moralidade comum encontra-se num estado de "equilíbrio reflexivo amplo", e, finalmente, que este equilíbrio no nível das intuições morais, máximas e princípios é importante como compreensão compartilhada das normas gerais por fornecer a introdução necessária ao engajamento na articulação de normas mais específicas.

Os defensores das teorias da moralidade comum não fornecem qualquer evidência sociológica, antropológica, histórica ou de qualquer tipo para suas pressuposições. E nem teriam como, pois, o que acontece é justamente o contrário, acredita Turner. Até mesmo se considerarmos apenas os Estados Unidos, afirma ele, e aceitando que há um núcleo moral enraizado no conceito de liberdade, até essa pressuposição, além de não universal, também carece de fundamento, pois, ao se deter o olhar mais profundamente sobre o país, percebe-se que a liberdade é privilégio dos mais ricos.

Turner caracteriza sua crítica à moralidade comum que dá suporte às teorias principialistas como simples e direta. Ele acusa os teóricos da bioética contemporâneos como Beauchamp e Childress de simplesmente não fornecerem qualquer evidência de qualquer natureza para sua afirmação. A plasticidade das formas de compreensão da moralidade nas diferentes culturas fornece, na verdade, a prova contrária. Isso vale até mesmo para um recurso utilizado por alguns teóricos da moralidade comum, que é o de recorrer à noção de direitos humanos como universal. Pois, além do fato de se tratar de algo recente na história, há várias percepções locais desse conceito, nas diferentes partes do mundo.

Também no que concerne ao equilíbrio reflexivo Turner alerta que, mesmo em países de cultura anglo-saxã, onde pode parecer haver um certo equilíbrio, que funciona como um solo comum de onde saem liberações legais e morais semelhantes, mesmo nestes, há conflitos morais profundos e eventualmente insolúveis. Dois exemplos seriam a filosofia para o sistema de saúde pública e a legalização ou criminalização do suicídio assistido por médico. Em ambos os casos não há concordância nem entre os diferentes países, nem dentro de cada país, ainda que momentaneamente prevaleça uma ou outra posição. 
Os princípios que seguem como consequência natural da moralidade comum não são, eles próprios, tranquilos, continua Turner. O significado que cada palavra tem será bem diferente a depender de quem a pronuncia. Um libertário entenderá a palavra autonomia de forma completamente diferente de um social democrata, por exemplo. Tomando o caso dos sistemas de saúde pública como exemplo, o princípio do respeito à autonomia pode ser contemplado de formas diferentes a depender da perspectiva que se adota, mesmo considerando-se apenas países anglo-saxões. Pessoas que abraçam a filosofia libertária defenderão que a saúde é um bem a ser adquirido, e os impostos devem se reduzir ao mínimo para possibilitar a máxima liberdade de consumo, respeitando-se, assim, a autonomia de cada um. Social democratas, por seu turno, defenderão a taxação progressiva, que distribuirá melhor os meios disponíveis, possibilitando a cada cidadão a liberdade para alcançar o sistema de saúde, já não mais um produto, mas, sim, um direito básico. No primeiro caso, predominante nos Estados Unidos, o conceito de autonomia está isolado dos demais. Já no segundo, predominante no Canadá, por exemplo, o conceito de autonomia está vinculado ao de justiça.

Um problema grave na tentativa de Beauchamp e Childress de escapar de uma prova empírica para sua teoria é bem apontado por Turner. A universalidade da moralidade comum valeria apenas para pessoas moralmente superiores. Pessoas imorais não teriam mesmo como aceitar a moralidade comum. Ora, de fato não se trata de excluir apenas psicopatas. Se fosse esse o caso, nem seria preciso mencionar a possibilidade. É claro que para esses nem a moralidade comum, nem qualquer outra tem sentido. Mas, ao mencionar essa possibilidade, fica implícito que quem não aceita a moralidade comum é amoral. É questionável e mesmo perigoso estabelecer um "nós" e um "eles", sendo "nós" os que aceitam os pressupostos da moralidade comum, e "eles" os amorais.

Ou a moralidade comum que Beauchamp e Childress propõem é uma versão de um universalismo moral fundamentado em conceitos morais apriorísticos, como uma abordagem neo-kantiana à deliberação moral, para a qual contraexemplos empíricos são irrelevantes, pondera Turner, ou seu núcleo moral é encontrado através do tempo e em diferentes sociedades. Beauchamp e Childress defendem ser o segundo caso, mas não apresentam evidências suficientes para tanto. 
Turner identifica a moralidade comum ao longo de seu artigo, o tempo todo como moralidade do senso comum, portanto intuitiva. $O$ que parece ser à primeira vista $\circ$ forte da proposta de Beauchamp e Childress vem a ser sua grande deficiência. Se é intuitivo, é autoevidente (como vimos em outras propostas de moralidade comum), portanto sem necessidade de uma fundamentação sólida.

É curioso notar que o mesmo Leigh Turner, em artigo anterior ao supracitado, faz uma crítica a algumas propostas de moralidade comum, sempre nominando como 'moralidade do senso comum', mas propondo a sua própria (194). A pluralidade de compreensões morais, mesmo dentro dos Estados Unidos, pondera Turner, torna bastante difícil que abordagens a partir da moralidade comum dos principialistas (assim dos casuístas) tenham sucesso. Apesar disso, a possibilidade de que indivíduos mudem de opinião quando suas crenças de base são eficazmente confrontadas, forneceria um vislumbre de uma possibilidade para uma moralidade do senso comum. A diferença entre esta sua proposta e a de outros, como Beauchamp e Childress, seria que a sua é bem mais modesta, resumindo-se a apenas um ponto - tolerância. Percebe-se aqui grande semelhança com a proposta de Engelhardt, iniciada com sua obra Bioehtics and Secular Humanism. The search for a common morality, de 1991, reforçada em The Foudations of Bioethics, de 1996. O mais curioso, porém, é o fato de Turner não fazer qualquer referência a si mesmo e sua própria proposta de moralidade comum quando elaborou sua crítica no artigo de 2003.

\subsection{Questões para o método do equilíbrio reflexivo}

DeGrazia (185) não chega a ser um crítico contundente de Beauchamp e Childress, reconhecendo, inclusive que estes deram ênfase numa espécie de pluralismo de forma crescente nas diferentes edições de seu Principles of Biomedical Ethics, culminando, na quinta edição, com uma enfática assimilação da moralidade comum como fonte das normas morais.

A aplicação dos princípios propostos por Beauchamp e Childress requer o exercício do equilíbrio reflexivo, também chamado de modelo de coerência para a justificação ética, por meio do qual aplica-se geralmente normas gerais para casos 
específicos, assim como utilizar a reflexão a partir de casos concretos para se revisar ou rejeitar uma norma geral. De Grazia considera que os autores não lançam mão, como deveriam, do recurso da justificação ética pela coerência, cujo elemento principal seria a plausibilidade. E identifica dois sentidos diversos para a moralidade comum. Moralidade comum 1 seria o grupo de crenças morais amplamente aceitas. Moralidade comum 2 seria o grupo de crenças morais alcançadas por meio do equilíbrio reflexivo, ou seja, o grupo de crenças morais que provavelmente seriam compartilhadas amplamente entre pessoas moralmente sérias que se utilizam de argumentos consistentes para ponderar acerca de seus julgamentos morais. Em outras palavras, a moralidade comum 1 seria a moral compreendida como simplesmente como costume, de forma acrítica. A moralidade comum 2 seria alcançada por meio de ponderações que se esforçariam por por estabelecer um equilíbrio reflexivo.

A moralidade comum do tipo 1 pode ser parecer intuitiva e óbvia, mas está sempre à mercê de costumes enviesados e francamente errados. DeGrazia menciona o pensamento socrático, que nos lembra que é sempre possível que $90 \%$ das pessoas estejam completamente equivocadas com relação a alguma crença moral. O fato de $90 \%$ das pessoas acreditarem que algo é certo não torna, forçosamente algo em moralmente certo. DeGrazia cita vários exemplos:

- Homossexualidade é moralmente problemática.

- As mulheres é que devem mudar seus nomes ao casar e desistir de sua carreira.

- A propriedade privada é sagrada.

- Se um casal rico mandar seu filho para a escola privada mesmo que a pública de seu bairro seja boa (portanto não tirando a vaga de uma criança pobre), e não contribui com nenhuma obra de caridade, ainda assim não falhou com sua obrigação de beneficência.

- Comer carne de animais é moralmente não problemático, assim como ir a um circo que tem animais.

- Animais existem para uso humano. 
Embora todos os exemplos dados sejam amplamente compartilhados, DeGrazia discorda de todos. Estão contaminados, respectivamente, por tradições religiosas, ideologia capitalista ou especismo. São todos preconceitos cristalizados em crenças morais amplamente compartilhadas. São características da moralidade comum tipo 1, a errada, de acordo com DeGrazia. Questionar tais preconceitos faz parte da moralidade comum tipo 2, acredita DeGrazia. Mas parece ser esta a privilegiada por Beauchamp e Childress, quando apresentam uma surpreendente capitulação, ao final do livro, afirmando que

talvez princípios gerais, análises de virtudes morais e declarações de direitos humanos é tudo a que podemos aspirar, em vez de uma teoria que se ajuste aos critérios delineados no capítulo 9. Talvez uma "teoria ética" está tão diluída em significado no caso de "teorias de moralidade comum" que deveríamos abandonar de vez o objetivo de uma teoria. (195 e 196)

Brand-Ballard (197) divide o debate bioético entre o que chama de descritivistas e principialistas, e questiona a pressuposição de ambas as propostas, de que a moralidade comum se constitui de um sistema normativo amplamente consistente.

Brand-Ballard considera que uma das vantagens do principialismo sobre o descritivismo é a opção do primeiro por uma epistemologia simétrica, enquanto o segundo opta por uma assimétrica. Esta daria preferência para normas gerais em detrimento de normas mais específicas, mesmo quando o resultado pode ser desastroso. Por exemplo, a norma geral "médicos não devem prescrever drogas que promovam o vício" conflitará com a necessidade de dar morfina a um paciente com dor extrema para qual somente a morfina resolve. Já a epistemologia simétrica conhecida como coerentismo permitirá que o médico revise seus conceitos baseados na norma geral para aquela situação específica, na qual a quebra da norma geral parece bem mais razoável. Brand-Ballard pondera que a posição dos principialistas, por aceitar tal possibilidade, aproxima-se mais do equilíbrio reflexivo ideal.

A epistemologia simétrica absoluta, diferentemente da qualificada, não apenas permite, mas exige que se dê preferência à norma mais razoável (de maior índice de confiança). O compromisso tácito dos principialistas com a epistemologia absolutamente simétrica, combinado com uma inconsistência das convicções das pessoas, levaria os principialistas a endossarem o pluralismo (que seria, então, uma 
forma "respeitável" de tolerar as inconsistências). Brand Ballard aponta exemplos de inconsistências prima facie na moralidade comum:

O povo americano, como um grupo, tem grande confiança de que é
impermissível matar uma pessoa para evitar a dor de cabeça leve de
milhões, e ainda assim, recusamo-nos a reduzir o limite de velocidade das
autoestradas. [...] Acreditamos que não aceitar abrir mão de nossos luxos
para salvar uma criança que agoniza é imoral, mas, ainda assim, nos
recusamos a sacrificar valores econômicos similares para prover cuidado
médico a crianças do terceiro mundo. (198)

De fato, se Brand-Ballard desenvolvesse um pouco mais essa linha de argumentação, fatalmente chegaria à conclusão de que a moralidade comum não só não é "comum" no sentido pretensamente universal do termo, mas, mesmo restrita à população dos EUA, carrega consigo profunda inconsistência.

O equilíbrio reflexivo proposto por Brand-Ballard é do tipo amplo, leva em consideração não apenas a coerência interna do grupo de normas morais em diferentes níveis de generalidade (equilíbrio reflexivo restrito), mas também toda uma gama de crenças não morais do indivíduo, tais como sobre a ciência, ciências sociais, metafísica, epistemologia, etc. Coerentistas valem-se do equilíbrio reflexivo amplo quando descartam convicções morais que até podem ser sincera e fortemente sentidas, mas não universalmente compartilhadas. Por exemplo, a oposição a casamento inter-racial não se sustenta como convicção moral séria, e deve ser encarada como uma idiossincrasia psicológica, consequentemente, desconsiderada. Esse é um caso típico em que o que se deve fazer é revisar a convicção interna em vez de generalizá-la. Outro exemplo mais contemporâneo é a instituição da obrigatoriedade de doação de órgãos postmortem independente do desejo manifesto previamente do doador, quando ainda vivo. Novamente, a oposição convicta a essa ação não se sustentaria a partir do momento em que se tivesse a segurança de que não ocorreriam abusos.

A conclusão de Brand-Ballard é que seria um erro imaginar que as teorias que se valem da moralidade comum, quer sejam descritivistas, quer sejam principialistas, deem conta tanto dos casos fáceis da ética clínica, quanto dos mais difíceis. Para tanto é preciso reconhecer que a moralidade comum carrega consigo uma incoerência, que deve ser corrigida adotando-se um equilíbrio reflexivo do tipo amplo. 
Outra crítica à forma com que o equilíbrio reflexivo é posto na estrutura da teoria da moralidade comum de Beauchamp e Childress parte de dentro do próprio grupo de Georgetown - a filósofa Rebecca Kukla. Num artigo recente (199), Kukla arrisca sua própria teoria de moralidade comum a partir de uma ponderação acerca do método de equilíbrio reflexivo e sua relação com a teoria da moralidade comum. Seu ponto de partida é o exemplo dado por Beauchamp e Childress sobre o código dos piratas, que teve o papel de mostrar que o equilíbrio reflexivo, por si só, não sustenta a moralidade comum. Sendo o código dos piratas ao mesmo tempo coerente e, portanto, passando pelo crivo do equilíbrio reflexivo, e moralmente condenável, coloca um problema à moralidade comum. Kukla discorda da solução encontrada por Beauchamp e Childress. Em primeiro lugar (e nesse caso Kukla tem razão), por que temos de assumir que o código dos piratas tem "coerência interna"? Seria preciso estar dentro do sistema dos piratas da época para admitir tal premissa. Mas, ainda que seja o caso, não se trata de analisar separadamente um código de condutas interno aparentemente coerente e em seguida contrapô-lo a um sistema externo, maior, que seria a moralidade comum. Isso porque, defende Kukla, não há um sistema interno inteiramente isolado. O que há são sistemas locais que frequentemente se entrecruzam. Piratas convivem com não-piratas. E os piratas não ficam surpresos se os não-piratas os condenarem moral e legalmente por seus malfeitos, já que eles sabem que são mal-feitos. Porque a definição de "mal-feito" está incorporada no "habitus", no dia-a-dia das pessoas. E é desse conviver cotidiano que sai a moralidade comum. Kukla acredita que o ser humano tem em sua natureza a capacidade de, mesmo em ambientes bastante diferentes dos que está acostumado, perceber o que causa nos outros indignação e condenação moral. A moralidade comum de Rebecca Kukla é, como ela própria classifica, "naturalista transcendental", pois "nossas observações diárias de nossa capacidade básica de se engajar em transações normativas uns com os outros torna claro [o fato de] que nós participamos conjuntamente de uma vida normativa razoavelmente estável". Trata-se de uma língua universal que torna a convivência entre humanos possível, a partir de suas características biológicas. E assim como há evolução na biologia, também esta moral comum se transforma. Kukla concorda, então com Beauchamp e Childress que 1- há uma moralidade comum e 2- que seu ponto de partida é naturalista, mas discorda que 1- esta moralidade comum esteja atrelada na dependência de um coerentismo advindo de um equilíbrio reflexivo, pois ela é pré- 
reflexiva e 2- que seja imutável.

Kelly-Herissone (200), por sua vez, considera dois pontos os mais problemáticos para a teoria da moralidade comum de Beauchamp e Childress. $\mathrm{O}$ primeiro seria a fundamentação sociológica desta, já que abundam evidências de moralidades particulares, e não de uma moralidade comum universal. Considera ainda que esta crítica foi satisfatoriamente resolvida na sexta edição de Principles of Biomedical Ethics pelo fato de seus autores considerarem tais moralidades particulares apenas como "especificações" diversas de princípios gerais comuns. $\bigcirc$ outro ponto que Kelly-Herissone considera problemático seria a proposta de Beauchamp e Childress para se testar experimentalmente sua teoria da moralidade comum. Kelly-Herissone se refere à sexta edição, mas tal proposta se encontra também, da mesma forma, na última (201). Beauchamp e Childress propõem a realização de um experimento que incluiria apenas pessoas seriamente comprometidas moralmente, e o "filtro" que determinaria tal comprometimento seria que tais pessoas aceitassem o princípio da não-maleficência como inegociável. Ora, uma crítica óbvia aqui, e que é também apontada por Kelly-Herissone, é o evidente viés de seleção de participantes de pesquisa. Afinal, para se testar se as pessoas aderem aos quatro princípios, já se as escolhe pelo critério de aceitar um dos desses princípios. Kelly-Herissone imbui-se, a seguir, da tarefa de "salvar" a tentativa de proposta de prova empírica para a moralidade comum. Ao fazê-lo, acaba sendo "mais realista do que o rei", imaginando um caminho que os próprios Beauchamp e Childress não ousaram. Kelly-Herissone pergunta: o que garante que pessoas que aderem ao princípio da não-maleficência também aderirão aos demais? $\mathrm{E}$ propõe uma versão da conectibilidade das virtudes: quem adere à não-maleficência possui a virtude da não-malevolência. A virtude da não-malevolência está forçosamente conectada à da benevolência, que sua vez está conectada com a da respeitabilidade, por sua vez com a da justiça. Como a virtude da benevolência é a necessária ao princípio da beneficência, da respeitabilidade ao do respeito à autonomia, e a virtude da justiça ao princípio da justiça, fecha-se o ciclo... virtuoso. Nem é preciso aqui procurar refutar a bizarra tentativa de Kelly-Herissone de ajeitar a teoria das virtudes à da moralidade comum, basta lembrar que os próprios Beauchamp e Childress não tiveram a pretensão de propor um resultado para seu experimento. Trata-se, claramente, de um experimento mental, para o qual os 
autores aceitam, inclusive, o insucesso (202), embora, evidentemente, apostem no sucesso. A despeito de sua tentativa, Kelly-Herissone conclui ser a tentativa de prova empírica da moralidade comum inútil, pois, ao necessitar saber de antemão quais normas morais seriam aceitáveis para qualificar pessoas moralmente comprometidas, por meio de uma profunda fundamentação conceitual, o experimento passaria a ser supérfluo.

\subsection{0 princípio do respeito à autonomia como ponto frágil}

Há várias formas de se abordar criticamente a teoria da moralidade comum, sendo a mais comum delas a falta de evidências de que ela de fato exista, considerando que se trata de uma descrição da natureza humana dando suporte a normas de conduta. Karlsen e Solbakk (203) também questionaram isso, mas o fizeram a partir de um dos princípios - o respeito pela autonomia. Não há como considerar este princípio como universalmente aceito ou mesmo que o tenha sido desde sempre. Autonomia é um conceito de certa forma recente, além do fato de sua interpretação (e, portanto, alcance) poder variar bastante em diferentes culturas.

Também Soren Holm teve como ponto de partida o princípio do respeito pela autonomia (204). Mas Holm é ainda mais crítico. O peso dado à autonomia, aliado à fraqueza do princípio de beneficência, são emblemáticos da perspectiva americana, acredita ele. A moralidade comum que sustenta a proposta de Beauchamp e Childress é a moralidade do senso comum americano, daí o peso dado à autonomia. Não passa nem perto de uma moralidade comum universal.

A beneficência "à maneira americana" é uma beneficência preguiçosa, descompromissada. É uma beneficência não obrigatória, que só será feita se não custar muito ao benfeitor. A equação "autonomia forte + beneficência fraca" tem como resultado uma noção de justiça também fraca, o que explica uma característica americana de adotar as regras de mercado para o sistema de saúde, em vez de privilegiar um sistema mais igualitário.

As críticas de Holm se parecem com as de autores latino-americanos, particularmente brasileiros, às quais passaremos a seguir. 


\subsection{As críticas ao Principialismo pela persectiva latino-americana}

Sem dúvida, entre os críticos mais duros da bioética principialista está Volnei Garrafa. Não especificamente contra a moralidade comum como fundamentação teórica de Beauchamp e Childress, mas, sim, ao sistema bioético proposto por autores anglo-saxões de forma geral, e Beauchamp e Childress, em particular. Na verdade, o próprio Garrafa demonstra em alguns de seus artigos críticos certa esperança de possibilidade de um terreno moral comum. Entretanto, há uma diferença importante. A "moralidade comum" (Garrafa não usa este termo) pela sua perspectiva não é legitimadora de uma maneira hegemônica e apolítica do pensar bioético, trata-se mais de um vislumbre de possibilidade de diálogo (no que de certa forma o aproxima da proposta de Engelhardt).

Em "Bioética, Poder e Injustiça: Por uma bioética de intervenção", Garrafa e Porto (205) estabelecem as condições para uma bioética engajada, completamente diferente da proposta pretensamente neutra e apolítica de autores como Beauchamp e Childress. Dividindo a bioética em de "situações persistentes" e de "situações emergentes", sendo as primeiras relativas a problemas antigos e persistentes tanto na área social quanto na área biomédica, e as emergentes ocasionadas pelas novas tecnologias, os autores frisam a necessidade de um papel ativo, político, para a bioética:

O que está acontecendo, muitas vezes, é a utilização de justificativas bioéticas como instrumentos, como ferramentas metodológicas, que acabam servindo de modo neutral apenas para a leitura e interpretação (acríticas) dos conflitos, por mais dramáticos que sejam. Dessa maneira, é atenuada (e até mesmo anulada, apagada...) a gravidade das diferentes situações, principalmente aquelas coletivas e que, portanto, acarretam as mais profundas distorções sociais.

O trecho destacado é bastante emblemático da forma completamente diferente de abordagem crítica partindo de um país periférico contra um país central, em comparação com as que partem de países centrais contra um de seus pares (tomando emprestado aqui os termos de Garrafa e Porto para caracterizar os países ricos e os em desenvolvimento). Com exceção do caso de Soren Holm (204), que faz uma crítica mais realista à proposta de Beauchamp e Childress, um padrão observável das críticas à moralidade comum em geral, e a Beauchamp e Childress em particular, é certa despreocupação com os aspectos globalmente práticos que 
são consequência natural da abordagem por eles criticada. No máximo há cuidado em se aplicar à realidade clínica, biomédica.

Mesmo reconhecendo a dificuldade de se transpor barreiras morais diversas, Garrafa e Porto defendem sua própria noção de moralidade comum (não com este termo), pois há "necessidade de estabelecer padrões universais para orientar o comportamento" (206). Tal necessidade advém por sua vez da necessidade de se estabelecer um diálogo entre os "com poder" e os "sem poder" que seja simétrico e anule o peso da hegemonia. Algo, reconhecem os autores, bastante difícil, já que tal necessidade será obviamente sentida de forma diferente por cada lado. Uma saída entrevista pelos autores é a diferenciação entre os conceitos de ética e moral, ficando a primeira como algo transcendental, acima das idiossincrasias, e a segunda, completamente exposta a tais idiossincrasias. Entretanto, tal solução podese mostrar não apenas inadequada, mas também potencialmente antiética. Como ilustração, imagine-se o caso de um padre com ativa atuação em favor dos socialmente vulneráveis, é procurado por uma adolescente já envolvida com drogas e prostituição para realizar 0 aborto. Imagine-se ainda que ela manifesta determinação em realizar o pretendido, mesmo se o religioso não a ajudar. Caso isso aconteça, as chances de tudo acabar mal são grandes. O padre respeita sua moral religiosa, mas uma ética superior paira acima desta moral, e ele decide ajudar a mocinha indicando alguém de sua confiança. Pronto, está resolvido o problema de consciência de nosso padre, que foi fiel tanto à sua moral particular, quanto a uma ética superior. Ou não. Aqui cabe recorrer aos existencialistas e sua noção ética de escolha. A atitude ética é a de assumir integralmente a responsabilidade por sua escolha, seja ela qual for. Se a ética (ou moral) mandava que ele ajudasse a mocinha em seu intento, que o fizesse a despeito do que a outra ética (ou moral) prescrevia. Ou que fizesse tudo a seu alcance para impedi-la de abortar. Note-se que tanto faz que se dê o nome de ética ou de moral, o que importa é a escolha. $E$ que se responda pelas consequências de tal escolha. De acordo com os próprios autores, a "ética não é quantitativa. Não se pode ser, por exemplo, 70\% ético. A ética é ou não é". (207)

Considerando-se que a proposta radical de Garrafa e Porto, a "bioética de intervenção", ainda se encontra em evolução, é interessante notar que no momento da publicação da citada obra (e ainda em algumas publicações subsequentes), a 
teoria ética que dá sustentação à bioética de intervenção é um consequencialismo do tipo utilitarista. Conceitos caros a esta proposta, tais como o balanço entre prazer e dor corporais, assim como cálculo do maior bem coletivo, são também caros à bioética de intervenção.

Com isso, por via diversa, Garrafa e Porto se aproximam de Engelhardt e até mesmo de Beauchamp e Childress quando se referem à importância de, pelo menos, não causar mal ("ao menos lutemos para que o poder de infligir a dor seja considerado abominável”, 208). Beauchamp e Childress também elegem a nãomaleficência como pré-requisito básico para determinar quem é moralmente comprometido, como visto anteriormente. Quanto a Engelhardt, em uma obra anterior à sua mais conhecida Foundations of Bioethics, propõe uma moralidade comum a partir do conceito de humanismo secular. Diferente do Humanismo Secular (com iniciais maiúsculas), o humanismo secular não seria uma forma de impor valores seculares a morais particulares com raiz religiosa (ou mesmo ideológica) (209). Ele reconhece ser muito difícil encontrar uma área comum para todas as possibilidades de morais particulares, mas também reconhece que há necessidade de se encontrar um terreno neutro. Tal posição seria ocupada pelo humanismo secular, que forneceria a desejada moralidade comum. Entretanto, dada a dificuldade de se encontrar um candidato que ocupe de forma pacífica esta posição, escolhe tão somente o respeito mútuo, ou seja, "o não-uso de outros sem seu consentimento". Mais adiante, em sua obra Foudations of Bioethics (210), ele traduzirá isso em linguagem de princípios, sendo este o "Princípio da permissão". E também nesta obra posterior ele acrescentará outro princípio, o da beneficência. Mas originalmente, quando tentou articular algo que se aproximasse de uma moralidade comum, Engelhardt limitou-se apenas ao "respeito mútuo", que nada mais seria do que o equivalente ao princípio do respeito pela autonomia, de Beauchamp e Childress. A pobreza do conteúdo da proposta de Engelhardt fica mais evidente quando ele o aplica à questão dos serviços de saúde, como se pode constatar pela sua opção pelo "livre" mercado:

O mercado é o resultado de numerosas ações consensuais entre indivíduos. Seus resultados são justificados pelo consenso entre os participantes. Em consequência, o mercado oferece uma forma de justiça em que cada um tem o que lhe cabe. (211)

Entretanto, cabe ressaltar que a proposta de Garrafa e Porto, exposta em 
mais de um momento (205, 212 e 213), a despeito da aproximação possível com a de Engelhardt, difere substancialmente desta. Para aqueles, a consequência lógica da existência de uma ética natural-transcendental, fundamentada nas características essenciais do ser humano, tem como consequência o reconhecimento de direitos básicos tais como o direito à vida e aos recursos naturais de forma justa e racional, do que se poderiam depreender categorias como libertação, responsabilidade, cuidado, solidariedade crítica, alteridade, comprometimento, transformação, tolerância, além dos "4 Ps" - prudência, prevenção, precaução e proteção. Já para Engelhardt, o mesmo ponto de partida leva a um caminho completamente diferente, a saber, o mercado como solucionador dos problemas.

Garrafa e Porto reconhecem que "quanto mais se busca por uma ética universal (sua moralidade comum), mais se depara com obstáculos aparentemente insuperáveis" (214). De fato, a busca por uma ética normativa universal fundamentada em características naturais/transcendentais do ser humano corre o risco de carecer de legitimação, configurando-se uma "falácia naturalista".

Este é o ponto de partida de Miguel Kottow, em sua crítica ao principialismo apresentada em "Bioética prescritiva. A falácia naturalista. O conceito de princípios na bioética" (215). Ele rejeita o naturalismo ético científico, mas acolhe o linguístico. Sua justificativa se parece bastante com a de Kukla (199), esta, para justificar sua própria proposta de moralidade comum. Pondera Kottow, fazendo referência a Pettit (216):

O enraizamento da linguagem moral na razão se explica porque o ser
humano não é apenas um ente intencional - que atua inconscientemente
segundo desejos e crenças que não exigiriam embasamento normativo -
mas ele também é um sujeito discursivo que expressa voluntariamente seus
estados intencionais por meio da linguagem de uso comum, possuindo
certos conceitos normativos associados ao raciocínio que permitem a
comunicação por meio do qual vivemos em um mundo de experiências
compartilhadas, utilizamos uma linguagem comum e possuímos a
competência de usar essa linguagem para indicar e compreender
significações que nos são familiares.(217)

O naturalismo ético linguístico, acredita Kottow (217), por se ancorar na razão e na linguagem comum, teria o potencial de ser universalizável sem ser absoluto, capaz de elaborar verdades morais revisáveis, ancoradas na evolução histórica. Mas o que seriam tais verdades morais universais revisáveis? Um bom candidato seria o imperativo categórico kantiano "age de tal maneira que uses a humanidade, tanto na 
tua pessoa, como na pessoa de qualquer outro, sempre e simultaneamente como fim e nunca simplesmente como meio" (218). Mas aqui Kottow dá uma interpretação própria, o que o aproxima dos autores que elegem a não-maleficência (para usar um termo principialista) como princípio básico de uma possível moralidade comum. "Usar a humanidade como meio" transforma-se em "prejudicar alguém como um fim em si" (219). Embora esta "tradução bioética" de um imperativo ético ajude a reforçar a ideia de universalidade, leva à pergunta: para que Kant? Algo mais antigo serviria (algo como "antes de tudo não causar dano", mas aí cairíamos no terreno movediço do principialismo).

Outro candidato a princípio universal de Kottow são os direitos humanos, que teriam a dupla característica para bom candidato pela sua perspectiva, a saber, "não se fundamentam na natureza antropológica" e "são de aceitação universal". A crença nessa segunda característica é a principal causa de serem os direitos humanos propostos por vários autores como o candidato ideal a uma moralidade comum, e sua principal falha, como veremos adiante.

Kottow critica a natureza prima facie dos princípios de Beauchamp e Childress, assim como sua inespecificidade. Mas o que propõem no lugar permanece sendo bastante próximo do que criticam. Por exemplo, no lugar do princípio do respeito à autonomia, propõem: "toda lesão intencional ao paciente deve contar com sua aprovação"(220). Beauchamp e Childress chamariam isso de "especificação", e é o que também propõem. É evidente que nenhum dos princípios se sustenta sozinho, todos necessitam de contextualização. Quanto ao caráter prima facie, Kottow propõe um candidato à primeira vista imbatível: "não aja sobre o meio ambiente de modo irreversivelmente destrutivo". De fato, o que poderia se sobrepor a tal assertiva? Mas não é preciso muito esforço para se imaginar uma situação emergencial em que, para salvar vidas humanas ou animais sejamos obrigados a realizar alguma ação irreversivelmente danosa ao meio ambiente. O mesmo se dá com o primeiro exemplo, se se tratar de paciente sem plena autonomia (crianças, pessoas com dificuldade momentânea ou permanente de cognição, etc), em que a não-maleficência se sobreporá ao respeito à autonomia (em linguagem intuitivamente principialista).

Uma crítica de Kottow ao principialismo é bastante pertinente. Trata-se de 
uma proposta inócua a aplicações mais abrangentes e não menos importantes do que a de uma simples ética biomédica, que é do que se trata a proposta de Beauchamp e Childress. Tentar adaptar o principialismo às inúmeras questões persistentes características dos países latino-americanos é um grande erro. Nesse sentido, o autor propõe dois postulados "sobre os quais não se pode transigir: a busca da justiça e o exercício da proteção" (221). Certamente poderíamos estender tal afirmação a todos os países periféricos.

Esta mesma crítica é apresentada de maneira um pouco diferente, quando Kottow, juntamente com Schramm (222), põem em xeque a bioética principialista, eminentemente uma bioética clínica, quando em contexto de saúde pública. Novamente recorre-se a um "princípio de proteção", que seria o resultado de uma "ética de responsabilidade" (a partir de conceitos dos filósofos Hans Jonas e Emanuel Lévinas). Schramm (223) apresenta as características dessa abordagem de uma forma que remete tanto ao princípio mínimo de Engelhardt (que chama de "nível básico" e "sofrimento evitável"), quanto à proposta da bioética de intervenção:

Devido a essas dificuldades de articulação entre o nível descritivo e o nível
normativo, a bioética de proteção acrescenta outro nível, que é justamente o
nível protetor. Mas esse não é propriamente um terceiro nível, e, sim, muito
provavelmente, o nível básico, o primeiro nível, pois se refere ao sofrimento
evitável, e que, por conseguinte, deve ser evitado, visto que esse nível pode
ser considerado aquele em que o prazer e a dor se confundem,
intuitivamente, com o bom e o mau. Com efeito, segundo Hans Jonas, essa
função protetora é bem conhecida pelos pais e mães que protegem seus
filhos até que possam desenvolver seus próprios meios para viver suas
vidas de modo responsável. Contudo, pode-se pensar a proteção não
apenas no sentido interpessoal, mas também social, por exemplo, em
medidas protetoras de um Estado social legítimo, que proteja, com
prioridade impreterível, seus cidadãos necessitados, ainda que isso levante
suspeita de "paternalismo", quase sempre considerado como um mal
porque impede que as pessoas se tornem autônomas e responsáveis por
suas vidas. (224) (Destaques nossos)

A teoria da moralidade comum é tratada como "fundamentalismo moral" por Tealdi (225). O caráter prima facie também é criticado de forma contundente por este autor, que associa esta característica à perda da primazia dos direitos humanos, estes sim, legítimos postulantes a uma "ética verdadeira", aos princípios. Isso porque seriam inalienáveis, universalizáveis, não negociáveis e absolutos (225). Trata-se, portanto, de mais um postulador dos direitos humanos como essência da moralidade comum. Há aqui, entretanto, uma diferença importante: Tealdi não fundamenta sua proposta de moralidade comum numa suposta aceitação geral dos 
direitos humanos. O que faz é propor, normativamente, os direitos humanos como o terreno por onde a moralidade comum transitará. Em outras palavras, não parte de uma suposição descritiva para uma proposta normativa, mas, sim, salta direto para esta última. O que parece mais acertado do que o que fizeram os demais autores que escolheram os direitos humanos. Partir da inferência de que são de aceitação universal é um erro no qual se perde a proposta para uma teoria de moralidade comum de seus propositores. A abordagem de Tealdi elimina esse erro. O que não significa que seja isenta, ela própria, de críticas. Stela Cerruti Basso, no comentário que faz ao citado capítulo (226), pergunta, pertinentemente: "O que seria uma 'ética verdadeira'? Ela se mostra uma proposta concreta para abordar a bioética de uma perspectiva latino-americana?" (226). E, ainda, não se comete o mesmo erro dos principialistas se não se construir a bioética para os países latino-americanos sem a ativa participação daqueles que, em teoria, queremos incluir? (226) 


\section{DISCUSSÃO}

\subsection{Existe uma moralidade comum?}

As abordagens críticas à teoria que pretende dar suporte ao principialismo têm um ponto recorrente - questionam a existência mesma de uma moralidade comum. É verdade que algumas dessas abordagens criticam o principialismo, mas propõem sua própria moralidade comum (Gert) ou não chegam a criticar o principialismo, mas as características da moralidade comum de Beauchamp e Childress (Kukla), propondo outras no lugar. Neste último caso a consequência prática acaba sendo a crítica ao principialismo, pois vai na raiz de sua fundamentação.

Esta é talvez a grande deficiência da proposta de Beauchamp e Childress. Pressionados a oferecer uma melhor fundamentação aos seus princípios de ética biomédica, particularmente pelas críticas de Clauser e Gert (186), propuseram, a partir da quarta edição, o que tomou corpo a partir da quinta edição, sua teoria de moralidade comum. Até então prevalecia algo que até a última edição ainda persiste, a saber, uma costura de retalhos das teorias éticas já existentes, algo duramente criticado por Clauser e Gert, e repetidas vezes pelo último. Entretanto, por não abraçarem a pretensão de criar uma teoria ética sólida, que mereceria uma obra a parte, Beauchamp e Childress ficaram a meio caminho entre esta tarefa e a mera proposta de um vislumbre de fundamentação. Isto fica explicitado pelos próprios autores no capítulo final da última edição de Principles of Biomedical Ethics, quando apresentam três diferentes possibilidades de comprovação de que sua teoria tem consistência - experimental (que chamam de 'empírica'), normativa e conceitual. Como nenhuma das três justificações alcança um nível decididamente satisfatório, sua inescapável conclusão é o reconhecimento de que sua teoria da moralidade comum deixa problemas sem resolver, que necessitariam de uma proposta teórica mais completa. (137)

A questão passa ser, então: uma teoria da moralidade comum melhor elaborada forneceria a prova de que ela, a moralidade comum, existe? $\mathrm{E}$, sendo este o caso, daria o suporte necessário à proposta principialista para uma ética 
biomédica? Mas o que vem a ser uma 'moralidade comum'?

\subsection{Do que falamos, quando falamos de moralidade comum?}

O primeiro ponto importante é reconhecer que a moralidade comum nem sempre leva esse nome. O que tem como consequência o fato de Beauchamp e Childress reclamarem para si a paternidade do termo, a despeito de Bernard Gert ter proposto antes, mas com outra denominação - 'moralidade como um sistema público'. Interessante notar que Beauchamp e Childress, mesmo em sua última edição, fazem questão de se referir à proposta de Gert dessa forma (7), ao criticá-la, e não como outra proposta de teoria de moralidade comum. Mas é isso que é a proposta de Gert, explicitada no título de sua obra Common Morality. Deciding What to Do, de 2004.

Moralidade comum, para Beauchamp, Childress e Gert, significa um conjunto de normas (regras, princípios, ideais) universalmente compartilhados por pessoas racionais (Gert) e moralmente comprometidas (Beauchamp e Childress), de forma natural, intuitiva. São normas óbvias demais para serem ignoradas, tais como "não mate", "não cause dano", "não engane", etc. Darão origem a regras e princípios, por sua vez com aplicação em situações biomédicas (Beauchamp e Childress).

Dois autores citados por Beauchamp e Childress não usam o termo 'moralidade comum', mas é o que propõem. No caso de um deles, é impressionante a proximidade de propostas entre aqueles e este - W.D. Ross. Embora Beauchamp e Childress não se refiram à sua própria abordagem como intuicionista (ou intuitiva), na prática é o que ocorre, pois o ponto de partida são crenças morais universalmente compartilhadas (ainda que devam ser submetidas ao processo do equilíbrio reflexivo), portanto pré-teóricas. Além disso, a noção de deveres prima facie e a própria lista destes deveres proposta por Ross é em muito semelhante à proposta de Beauchamp e Childress.

O outro autor é Alan Donagan, talvez o único a apresentar uma teoria de moralidade comum (que ele chama apenas de "teoria da moralidade") com uma 
abordagem mais sólida. Moralidade comum, para Donagan, é a aplicação da regra de ouro (Não faça com os outros o que não deseja que faça com você mesmo), traduzida filosoficamente pelo imperativo categórico kantiano - : "Age de tal maneira que uses a humanidade, tanto na tua pessoa como na pessoa de qualquer outro, sempre e simultaneamente como fim e nunca simplesmente como meio." Refutar Donagan equivalerá, basicamente, a refutar Kant e sua ética de deveres como imperativos categóricos que desconsideram os fins e as consequências.

Precedendo em um ano a publicação da quarta edição de Principles of Biomedical Ethics, a obra Prospects for a common morality (227) propôs a tarefa de responder à pergunta se seria possível uma moralidade comum a treze diferentes autores. Alan Gewirth (228.), David Little (229) e Annete C. Baier (230) propõem os direitos humanos como o candidato a ocupar o lugar de uma moralidade comum.

Gerwith (228) propõe três passos para a justificação dos direitos humanos como moralidade comum. Primeiro, o conceito de 'direitos' está intimamente relacionado à ideia de 'interesses justificados'. E a justificação não repousa, por sua vez, numa ideia de 'interesses que levem a uma maximização da utilidade social'. Repousa, unicamente, no fato de que se trata de demanda legítima: "Fulano tem direito a...". O segundo passo é enfatizar a palavra 'humanos' em 'direitos humanos', no sentido de abarcá-los todos. O terceiro e mais difícil passo seria: Como aplicar o conceito de direitos comuns a todos convincentemente? A solução encontrada por Gerwith é semelhante a outras propostas de moralidade comum, simplificar ao máximo os direitos, reduzindo-os ao básico, com isso eliminando os interesses conflitantes. Estes seriam apenas dois: liberdade e bem-estar.

Já Little (229) propõe como ponto de partida os direitos humanos dos documentos e tratados internacionais que, acredita ele, seriam uma prova de que um vocabulário minimamente acordado entre os povos é possível. O vocabulário dos direitos humanos, seria, então, a base da moralidade comum. Baier (230), por sua vez, concentra seu foco na linguagem dos direitos humanos, e no 'direito a ter voz'. Fazer-se ouvir como um direito humano básico teria como consequência, pelo menos, o direito a não ser torturado, que garantiria que a voz não fosse trocada pelo grito de dor. Também Baier, portanto, reduz sua moralidade comum a um mínimo. 
Robert Merrihew Adams (231) e Gene Outka (232), assim como Alan Donagan, que também participa desta obra com um capítulo (233), têm na religião seu candidato ideal para a moralidade comum. Quanto a Donagan, como já visto, ele associa a religião com os imperativos categóricos kantianos. Para Adams, para a moralidade comum existir, há pré-requisitos sociais e políticos. A sociedade deve ser capaz de conviver bem com o pluralismo, e, para tanto, religião e estado devem estar separados. De acordo com ele, a única religião que preenche esse requisito é a cristã, pois

o judaísmo, como a fé dominante de um grupo étnico, e profundamente conectada com seu senso de nação, não faz distinção clara entre Igreja e Estado; e o islamismo, como uma fé que começou como uma campanha militante para reconfigurar toda uma sociedade, é menos inclinada distinguir entre instituições religiosas e políticas. (234).

Outka, por seu turno, assim como Donagan, escolheu a chamada "regra de ouro" (não faça com os outros o que não deseja que seja feito com você) como base de sua moralidade comum. Entretanto, a perspectiva de Outka, diferente da de Donagan, não alia a regra religiosa com os imperativos laicos kantianos. Para Outka, é o espírito que está em jogo quando se quebra a regra.

Para Margaret A. Farley (235) o feminismo está em posição privilegiada para enxergar melhor o que há em comum entre os seres humanos, porque as mulheres, diferentemente dos homens, estiveram submetidas a estruturas determinantes da experiência de forma universal, que foi sua subordinação aos homens, assim como seu papel no ambiente doméstico e econômico. Outra contribuição do feminismo seria a noção de dano à integridade corporal, que, pela perspectiva feminista seria mais uma questão ligada à autonomia do que à não-maleficência, para usar linguagem principialista.

A proposta de John P. Reeder, Jr. (236) para uma moralidade comum é o que ele denomina "neopragmatismo". Há ilhas de moralidades no mundo, mas estas não são incomunicáveis. "Concretos universais" estabelecem a possibilidade de compreensão mútua que seria o substrato para uma moralidade comum. Um exemplo seria a categoria "opressão". Trata-se de um concreto universal (um conceito universalmente compreendido). Entretanto, oprimidos e opressores compreendem a mesma palavra de modo diferente, reconhece Reeder Jr. E, neste caso, oprimidos devem ter voz prioritária na comunicação, mas esta permaneceria 
sendo uma via dupla, em que opressores também tivessem voz.

Jeffrey Stout (237) reconhece que não existe tal coisa como uma regra moral universal e igualmente aceita por todos os povos de todos os lugares em todos os tempos. As diferenças são muitas. Mas as semelhanças também, e é isso o que permite acreditar na possibilidade de uma moralidade comum. Um elemento chave seria, então, a humildade em se reconhecer que um determinado candidato a moralidade comum se revele insatisfatório com o tempo. Outro elemento chave seria a possibilidade de que uma determinada categoria moral, ainda que não seja reconhecida pela maioria das pessoas, possa ser uma verdade moral. O que também envolve a humildade de perceber tal possibilidade. Humildade seria, então, o núcleo da moralidade comum de Stout.

Lee H. Yearley (238) escolhe o caminho da ética das virtudes como o que possibilita uma moralidade comum. Seu ponto de partida é que seja evidente que todos "concordemos que precisamos de proteger um grupo mínimo de injunções abstratas e universalmente válidas" (238). A moralidade comum nos forneceria a capacidade, mesmo através de culturas e religiões diferentes, de identificar e nos mirar na figura do "homem bom".

Richard Rorty (239) aposta nas regras de um Sistema democrático como sendo o terreno da moralidade comum. E aqui difere radicalmente de todos os autores que escolheram a religião como ponto de partida. Considera essencial o laicismo da sociedade civil democrática, não no sentido de que seja ruim que os cidadãos tenham religião e a pratiquem, mas no sentido de que seja lá qual for a religião que tiverem, sua prática deve ser de tal forma que não interfira no bom funcionamento da sociedade democrática. Em outras palavras, fanáticos não são bem-vindos, pois suas crenças e atitudes não poderão ser justificadas para a maioria. Defende ainda, e nesse ponto de certa forma até se aproxima da Bioética de Intervenção, que as muitas demandas sociais e políticas exigem que se parta para a ação, tendo a as regras da sociedade democrática como sustentação à solução dos conflitos.

Um autor que também defendeu uma proposta de moralidade comum com este nome foi Engelhardt (209), para quem esta seria alcançada por meio de um 
humanismo secular. Também Engelhardt reconhece a dificuldade de se estabelecer normas de aceitação universal, o que o força a se restringir a uma única: respeito mútuo.

\subsection{Moralidade comum com outro nome}

Embora alguns dos autores citados anteriormente não tenham usado exatamente o mesmo termo, como Donagan e Ross, estes construíram deliberadamente uma teoria com pretensão de uma moralidade comum. Um fato interessante no curso da investigação para a realização deste trabalho foi constatar que praticamente todos os autores consultados também acabaram por propor alguma forma de moralidade comum.

Uma característica evidente na abordagem dos bioeticistas latino-americanos é o viés social e político de suas propostas. Enquanto as abordagens com origem em países ricos preocupam-se essencialmente com a fundamentação filosófica, frequentemente descuidando das consequências práticas para a comunidade global, as latino-americanas concentram seu foco na capacidade de solução prática de problemas persistentes, ou mesmo os sociais causados por questões emergentes.

A despeito do foco diferente, as abordagens pela perspectiva latinoamericanas também arriscam a possibilidade de uma moralidade comum. Garrafa e Porto, por exemplo, (205, 212 e 213), ponderam que o estabelecimento de uma diferença entre as palavras 'ética' e 'moral' permitiria associar-se a última a 'morais particulares', culturalmente construídas, enquanto 'ética' seria algo transcendental que paira sobre todas estas moralidades particulares, como uma possibilidade de diálogo e compreensão mútua. A natureza corpórea do ser humano, com sua capacidade para sentir dor e prazer também seria algo universal e, consequentemente, terreno possível para uma moralidade comum. Não causar dor se colocaria como um parâmetro mínimo de aceitação universal. O que nos remete à exigência de Beauchamp e Childress para a pretensa amostra para seu experimento da moralidade comum - que seja constituído apenas por pessoas que aceitam, no mínimo, o princípio da não-maleficência como inegociável. Certamente, nem a Bioética de Intervenção se resume ao mínimo aceitável, nem também o 
Principialismo se resume à não-maleficência. $E$, se há eventuais pontos de partida semelhantes, certamente os de chegada foram bem diversos.

Miguel Kottow (215) rejeita o naturalismo ético científico, mas acolhe o linguístico, fazendo com que sua proposta - o naturalismo ético linguístico - pareçase com a de Rebecca Kukla (199). Por se ancorar na razão e na linguagem comum, o naturalismo ético linguístico (a moralidade comum de Kottow), teria o potencial de ser universalizável sem ser absoluto, capaz de elaborar verdades morais revisáveis, ancoradas na evolução histórica. Outro candidato a moralidade comum seriam os direitos humanos, que seriam "de aceitação universal". Mas essa crença (de que os direitos humanos gozam de aceitação universal) está longe da realidade encontrada nas diferentes partes do mundo.

Schramm (223), por sua vez, proporá como um "nível básico" universalizável (sua moralidade comum), o evitar o sofrimento, postulando o Estado como principal responsável pela garantia de proteção àqueles mais vulneráveis a que se aconteça o "sofrimento evitável".

A teoria da moralidade comum é tratada como "fundamentalismo moral" por Tealdi (225), mas ele propõe a sua própria, que seria, como outros autores propuseram, os direitos humanos, legítimos postulantes a uma "ética verdadeira" (sua moralidade comum). Isso porque seriam inalienáveis, universalizáveis, não negociáveis e absolutos.

A pergunta persiste teimosamente: Existe, de fato, uma moralidade comum?

Elencar as várias e díspares abordagens à possibilidade de uma moralidade comum permite enxergar que:

1- Trata-se de uma angústia generalizada.

2- Não existe.

3- É inútil e perigoso insistir em sua existência.

Não chega a ser surpresa que bioeticistas se esforcem na busca de uma teoria ética geral, que dê conta de todas as situações potencialmente conflituosas no 
vasto campo da bioética. Filósofos morais fizeram o mesmo. Mas também não é nenhuma surpresa que esta tarefa se mostre infrutífera.

Parece inevitável que, para se chegar a um destino comum, parta-se sempre de um ponto à primeira vista óbvio. Pois o que pode ser mais óbvio do que a natureza humana? O que pode ser mais natural do que inferir que ninguém quer sentir dor, ou que todos concordam com condutas básicas para uma convivência harmônica? Ou que direitos humanos sejam naturais? Ou que haja uma linguagem universal que permeia as várias diferentes culturas, fornecendo-lhes a ponte necessária para um entendimento mútuo? Ou que haja uma ética transcendental que acima das muitas morais particulares?

A questão é que, ainda que tudo isso seja verdade (no sentido experimentalmente verificável), por que disso se seguirá qualquer norma? Por que, da constatação de nossa finitude e interdependência se segue que devamos nos tratar com consideração e respeito? Posso agir com consideração e respeito, ou não, independentemente de ter consciência disso. Ou posso justificar uma falta de consideração mesmo sabendo que sou finito e dependo dos demais.

O que determinará meu comportamento moral será minha adesão voluntária a um sistema específico de normas que eu desejar para mim. Concordando com Brito (240), "não há um sentido objetivo para a justificação moral, ou seja, um sentido independente de nossas preferências subjetivas".

Vários autores se deram conta dessa dificuldade, e, embora com a esperança de propor uma moralidade comum, contentam-se com um mínimo, um item básico que pode ser o "respeito mútuo" (Engelhardt), ou "não causar dor/sofrimento" (Garrafa e Porto, Kottow e Schramm), ou, simplesmente, diálogo (Kukla). Mas fica logo evidente, e alguns autores reconhecem isso (como Garrafa e Porto, por exemplo), que este mínimo é pouco demais, insatisfatório para, efetivamente, solucionar os problemas reais que se apresentam, tanto no terreno mais restrito da ética biomédica, quanto no mais amplo, da bioética.

Voltando à proposta de Beauchamp e Childress, pode-se fazer o mesmo questionamento. Além das críticas elencadas anteriormente, cabe ainda (e principalmente) a ponderação de Brito citada acima, de que nossa adesão a 
determinada justificação moral se dará na medida em que o queiramos, movidos por nossas preferências pessoais. A aceitar a advertência de Brito, elimina-se por completo a possibilidade de uma "moralidade comum como moralidade universal".

Mas não é apenas inútil se insistir na existência de uma moralidade comum, é também perigoso. Além do risco de ser anti-ético ao usar a separação dos termos ética e moral discutido anteriormente, há o risco apontado por Tealdi (225), do "fundamentalismo moral". Um exemplo contemporâneo real serve bem à ilustração do temor de Tealdi. O movimento "Black lives matter" surgiu recentemente nos Estados Unidos, em resposta ao assassinato de jovens negros americanos em quantidade desproporcionalmente superior ao de brancos daquele país. Trata-se de uma forma de chamar a atenção da sociedade a uma estatística escandalosamente imoral de sua polícia. Sendo uma característica da direita americana o desprezo por dados estatísticos e evidências científicas (como se vê no caso do aquecimento global), seus representantes passaram a refutar o slogan do movimento negro com outro - "All lives matter".

"Todas as vidas importam" faz bastante sentido e parece irrefutável, por seu alcance pretensamente universal. Se alcança mais gente, é mais ético, segue o argumento. (Ou caberia também dizer, se é universal, é mais ético). Entretanto, "todas as vidas" não estão sendo afetadas igualmente. Há grande desproporção desfavorável para as vidas negras. Nesse sentido, o slogan que à primeira vista é "mais ético", por ser universal, acaba sendo profundamente imoral, por encobrir um fato real, que precisa de muito mais atenção e cuidado por parte da sociedade (aí sim, toda ela) e, principalmente, aqueles que têm o poder de consertar o que está errado. Sendo os Estados Unidos um país democrático, o movimento chama a atenção de cidadãos que votam, negros ou não. Diante disso, "All lives matter" serve apenas como arma de poder para tentar impedir mudanças no status quo, favorável a seus propositores. Uma arma (supostamente) democrática, contra o exercício da democracia. 


\section{CONSIDERAÇÕES FINAIS}

A aceitação e popularidade de Principles of Biomedical Ethics no meio biomédico é inegável. Já a partir das primeiras edições, com ou sem teoria de moralidade comum dando-Ihe suporte. De onde viria tamanha popularidade?

Pode-se especular, a despeito da discordância de seus propositores (136), que sua moralidade comum nada mais seja do que "hábito". Moralidade como costume. O que seria suficiente, a seguirmos o pensamento de John Dewey: "Para propósitos práticos, moral significa costume, tradições populares, hábitos coletivos estabelecidos." (241) Mas Beauchamp e Childress não só não recorreram a Dewey, como certamente o refutariam. A ironia fica por conta da previsão deste que acaba por se aplicar àqueles: "(...) o principal efeito prático de se recusar a reconhecer a conexão entre costume e padrões morais é deificar algum costume especial e tratalo como essencial, imutável e imune a críticas e revisões." Pois foi exatamente o que aconteceu com a moralidade comum de Beauchamp e Childress. Entretanto, retirando-se a moralidade comum, sobram princípios soltos e não-hierarquizados, que nada mais são do que fruto da tradição (hábitos, costumes) de um grupo de pessoas que realiza a mesma tarefa.

Os princípios de Georgetown representam não uma moralidade universal, mas, sim, particular, peculiar aos meios biomédicos. Nesse sentido, gozam de rápida e intuitiva incorporação ao vocabulário e modo de pensar biomédico, portanto na prática clínica e, em certa medida, também nas pesquisas biomédicas. São elementos de uma gramática moral assimilada desde os primeiros anos de formação de profissionais da saúde, que passam a se valer dela em seu dia-a-dia, de forma quase medular (novamente Dewey). Não-maleficência, beneficência e, mais recentemente, respeito à autonomia e justiça são levados em consideração, nem sempre "dando-se nome aos bois". Pode-se vocalizar um raciocínio para justificar uma decisão tomada em que se decidiu não tratar um paciente porque este não quis, sem pronunciar uma única vez a palavra autonomia. Ou solicitar a intervenção do poder judiciário para fazer uma transfusão de sangue numa criança filha de Testemunhas de Jeová que não querem o procedimento, sem dizer que se está colocando a não-maleficência em primeiro lugar. E assim por diante. As crenças 
compartilhadas no meio biomédico prescindem dos pressupostos da moralidade comum. Basta-Ihes a intuição dos princípios.

A teoria da moralidade comum de Beauchamp e Childress não é apenas insatisfatória para fundamentar sua proposta principialista, mas também desnecessária, se considerarmos o principialismo como uma forma de moralidade particular, do meio biomédico. Diante disso, será um grande erro qualquer forma de aproveitamento do principialismo como teoria do conhecimento bioético, pois não é disso que se trata. Particularmente em casos que envolvam questões sociais persistentes, e particularmente nos países periféricos.

Como dito antes, a força do Principialismo também é sua fraqueza. Do fato de ser extraído dos costumes das pessoas do meio biomédico, é automaticamente assimilado. Mas é só isso que é: uma descrição dos hábitos destas pessoas, não se prestando ao papel normativo necessário. É um árbitro ruim, porque também é um jogador.

A busca por uma moralidade comum, mesmo com outros nomes ("ética verdadeira", "ética natural linguística", "ética geral”, ou simplesmente "ética") mostrarse-á sempre infrutífera. Ou não será "comum", ou não será "moralidade". Em outras palavras, se se propuser uma tarefa mais ousada, apresentando candidatos com pretensa aceitação universal (direitos humanos, por exemplo), ver-se-á obrigada a recuar e enxugar ao máximo sua 'moralidade' para ser mais 'comum'. Mas aí, ficará tão esvaziada, tão mínima, que não será suficiente como 'moralidade' (diálogo, por exemplo).

Talvez caiba, então, resgatar o termo "Bioética Dura" como sinônimo de "Bioética de Intervenção" (215). O fracasso pela busca de uma moralidade comum nos ensina que: 1- Está na hora de parar de perder tempo com isso. 2- É preciso dialogar com todas as morais particulares, sem exceção. 3- Há um momento em que o diálogo deve ceder lugar à decisão. 4- A decisão final deve sempre levar em consideração o maior bem para o maior número de pessoas, exceto quando isso acarretar prejuízo significativo para uma determinada minoria particularmente vulnerável, que, neste caso, deverá receber a intervenção afirmativa do Estado. 0 papel da Bioética Dura seria o de arbitrar e intervir, sempre que necessário, para que 
o objetivo 4 seja alcançado. Seria uma bioética que, sem desconsiderar a natureza humana, não terá esta como ponto de partida para o estabelecimento de normas, que serão sempre circunstanciais em relação a um objetivo específico. Uma ética de imperativos hipotéticos, bem distantes da moralidade comum principialista. 


\section{REFERÊNCIAS}

1. Beauchamp TL, Childress JF. Principles of biomedical ethics. 7.ed. New York: Oxford University Press, 2013.

2. Ibidem; 2-3.

3. Ross WD. Foundations of ethics. London: Oxford University Press, Kindle Edition, 1939.

4. Donagan A. The theory of morality. Chicago: The University of Chicago Press, 1977.

5. Gert B. Common morality. Deciding what to do. New York: Oxford University Press, 2004.

6. Beauchamp TL, Childress JF. Op.cit. 2013; 25-6.

7. Ibidem; 393-7.

8. Ibidem; 394.

9. Ibidem; 419.

10. Gert B. Op. cit. 2004; 3-17.

11. Ibidem; 9.

12. Maclntyre A. Dependent rational animals. Why human beings need the virtues. Chicago: Open Court, 1999.

13. Paranhos FRL. Resenha de Dependent Rational Animals, de Alasdair MacIntyre. Philósophos Revista de Filosofia da Universidade Federal de Goiás. 2001;6(1/2):137-43.

14. Gert B. Op. cit. 2004; 13-5.

15. Ibidem; p. 15-6.

16. Ibidem; 19-20.

17. Ibidem; 20-1.

18. Ibidem; 22.

19. Ibidem; 22-3. 
20. Beauchamp TL, Childress JF. Op. cit. 2013; 396- 7.

21. Garrafa V, Porto D. Bioética poder e injustiça: por uma ética de intervenção. In: Garrafa V, Pessini L. Bioética: poder e Injustiça. São Paulo: Loyola; 2003; 35-44.

22. Garrafa V. Da bioética de princípios a uma bioética interventiva. Bioética. 2005;13(1):130.

23. Gert B. Op. Cit. 2004; 29-30.

24. Ibidem; $31-2$.

25. Ibidem; 34 .

26. Ibidem; 35- 8.

27. Ibidem; 38-9.

28. Ibidem; 40- 1 .

29. Ibidem; 42- 4 .

30. Ibidem; 44-5.

31. Ibidem; 47-9.

32. Ibidem; 50- 3.

33. Ibidem; 26- 9.

34. Beauchamp TL, Childress JF. Op. cit. 2013; 416- 17.

35. Strong C. Gert's moral theory and its application to bioethics cases. Kennedy Institute of Ethics Journal. 2006;16(1): 39-58.

36. Gert B. Op. cit. 2004; 97.

37. Ibidem; 113.

38. Paranhos FRL. Cobaias humanas. In: Cinema \& Filosofia, Kindle Edition, 2013.

39. Arendt H (Trad. Rosaura Eichenberg). Algumas questões de filosofia moral. In: Responsabilidade e julgamento. São Paulo: Cia das Let.; 2003; 118.

40. Gert B. Op. cit. 2004; 123.

41. Kant I. Crítica da razão prática. Lisboa: Edições 70, 1999; 42. 
42. Platão. A República, tradução e notas de Maria Helena da Rocha Pereira; 9. ed. Fundação Calouste Gulbenkian, 2001; 359 a-e, 360a-d.

43. Ibidem; 344b-c.

44. Gert B. Op. cit. 2004; 83.

45. $\quad$ Strong C. Op. cit. 2006; 46.

46. Beauchamp TL, Childress JF. Op. cit. 2013; 397.

47. Donagan A. Op. cit. 1977; 7.

48. Ibidem; 6-7.

49. Ibidem; 4.

50. Aquinas St. Thomas. Teatrise on law. Washington: Gateway Editions, Regnery Publishing, Inc. 2001; 54-72.

51. Ibidem; 56- 7 .

52. Ibidem; 57-61.

53. Ibidem; 61-3.

54. Beauchamp TL, Childress JF. Op. cit. 2013; 17.

55. Aquinas St. Thomas. Op. cit. 2001; 64- 7.

56. Ibidem; 67- 70 .

57. Ibidem; 71-2.

58. Donagan A. Op. cit. 1977; 52-3.

59. Ibidem; 54.

60. Ibidem; 56-7.

61. Ibidem; 57-8.

62. Ibidem; 58.

63. Ibidem; 59.

64. Ibidem; 59-60.

65. Ibidem; 60-3.

66. Ibidem; 65. 
67. Ibidem; 77.

68. Kant I. Metafísica dos costumes. Trad. Clélia Aparecida Vozes, 2013; 229 261.

69. Donagan A. Op. cit. 1977; 78.

70. Ibidem; 80.

71. Ibidem; 82-3.

72. Ibidem; 85-6.

73. Kant I. Fundamentação da metafísica dos costumes. Trad. Paulo Quintela. Edições 70, 1997; 72- 8.

74. Donagan A. Op. cit. 1977; 92-3.

75. Ibidem; 94- 100.

76. Ibidem; 101.

77. Ibidem; 101-8.

78. Ibidem; 109.

79. Ibidem; 108-111.

80. Ibidem; 115.

81. Ibidem; 118.

82. Ibidem; 121.

83. Ibidem; 127.

84. Ibidem; 128.

85. Ibidem; 131-8.

86. Ibidem; 138- 42 .

87. Ibidem; 144- 45.

88. Ibidem; 254.

89. Ibidem; 146- 7 .

90. Kant I. Op. cit. 2013.

91. Donagan A. Op. cit. 1977; 30. 
92. Ibidem; 149.

93. Ibidem; 158.

94. Ibidem; 154.

95. Ibidem; 155.

96. Ibidem; 159.

97. Ibidem; 160-3.

98. Ibidem; 172-209.

99. Ibidem; 187.

100. Ibidem; 209.

101. Ibidem; 238.

102. Kant I. Op. cit. 1997; 50.

103. Ibidem; 50-4.

104. Ibidem; 57.

105. Ibidem; 59.

106. Ibidem; 69.

107. Donagan A. Op. cit. 1977; 214.

108. Foot P. Morality as a system of hypothetical imperatives. The Philospphical Review. 1972;1(3): 305-16.

109. Ross WD. Op.cit. 1939; posição 283-453.

110. Aristóteles. Ética a Nicômaco. Trad. Leonel Vallandro e Gerd Bornheim, a partir da tradução para o inglês de W.D. Ross. In: Os Pensadores - Aristóteles Volume II, Nova Cultural. 1987; 117.

111. Kant I. Op. cit. 2013; 19- 20.

112. Ross WD. Op.cit. 1939; posição 454- 930.

113. Ibidem; posição 987.

114. Ibidem; posição 1003.

115. Ibidem; posição 1013- 18. 
116. Ibidem; posição 1034.

117. Ibidem; posição 1096.

118. Ibidem; posição 1137.

119. Ibidem; posição 1582.

120. Ibidem; posição 1591.

121. Ibidem; posição 1604.

122. Ibidem; posição 1638.

123. Ross WD. The right and the Good, 1930. Verbete William David Ross. Encyclopedia of Philosophy. [internet] Disponivel em http://plato.stanford.edu/entries/william-david-ross/. Acesso em 02 jan. 2015.

124. Kant I. Metafísica dos costumes. Trad. Clélia Aparecida Martins, Bruno nadai, Fernando Costa Mattos, Monique Hulshof, Nathalie Bressiane, Ricardo Terra, Diego Kosbiau. Petrópolis: Vozes; 2013.

125. Ibidem; 30.

126. Ross WD. Op.cit. 1939; posição 1716.

127. Frankena W. Ethics. 2nd. New Jersey: Prentice Hall, 1973; 16.

128. Canto-Sperber M, Ogien R. O que devo fazer? A filosofia moral. Trad. Benno Dischinger. São Leopoldo: Unisinos, 2004; .56.

129. Ross WD. Op. cit.; posição, 3366.

130. DeGrazia D. Common morality, coherence, and the principles of biomedical ethics. Kennedy Institute of Ethics Journal Vol. 13, No. 3; 2003; 220.

131. Beauchamp TL, Childress JF. Op. Cit.; 5.

132. Ibidem, 3 .

133. Brito NA. (Org). Ética. Questões de fundamentação. Brasília: UnB, 2007; 1935.

134. Beauchamp TL, Childress JF. Op. cit.; 410.

135. Ibidem; 15.

136. Ibidem; 411. 
137. Ibidem; 422.

138. Ibidem; 405.

139. Ibidem; 407.

140. Ibidem; 202.

141. Ibidem; 203.

142. Clouser KD, Gert B. A critique of principlism. The Journal of Medicine and Philosophy; 1990; 15: 228.

143. Beauchamp TL, Childress JF. Op.cit.; 207.

144. Ibidem, 211.

145. Ibidem; 212.

146. Ibidem; 215.

147. Ibidem; 222.

148. Ibidem; 226.

149. Ibidem; 227.

150. Ibidem; 240.

151. Ibidem; 152.

152. Ibidem; 154.

153. Ibidem; 155.

154. Ibidem; 156.

155. Ibidem; 157.

156. Ibidem; 158.

157. Ibidem; 165.

158. Donagan A. Op. cit.; 102-105

159. Beauchamp TL, Childress JF. Op. cit.; 166.

160. Donagan A. Op. cit.; 105.

161. Foot P. The problem of abortion and the doctrine of the double effect. Oxford Review, 1967, 5: 5-15. 
162. Beauchamp TL, Childress JF. Op. Cit.; 168.

163. Ibidem; 175.

164. Ibidem;182-183.

165. Ibidem; 185.

166. Ibidem; 187-188.

167. Ibidem; 250.

168. Ibidem; 253.

169. Ibidem; 262.

170. Ibidem; 263.

171. Ibidem; 264.

172. Ibidem; 270.

173. Ibidem; 272.

174. Ibidem; 274-276.

175. Ibidem; 279.

176. Ibidem; 279-280.

177. Ibidem; 184.

178. Ibidem; 101.

179. Ibidem; 104.

180. Gadamer H-G. Autoridade e liberdade crítica. In: Gadamer H-G. O caráter oculto da saúde. Rio de Janeiro: Vozes, 2006; 122-129

181. Beauchamp TL, Childress JF. Op. cit.; 107.

182. Ibidem; 109-110.

183. Ibidem; 113.

184. Ibidem; 126.

185. DeGrazia D. Op. cit.; 219-230.

186. Clouser KD, Gert B. Op. cit.: 219-236. 
187. Ibidem; 236.

188. Ibidem; 223.

189. Gert B. Morality: a new justification of the moral rules, 1988; 235.

190. Ibidem; 226.

191. Ibidem; 227.

192. Beauchamp TL, Childress JF. Op. cit.; 393.

193. Turner, L. Zones of consensus and zones of conflict: Questioning the "Common Morality" presumption in bioethics. Kennedy Institute of Ethics Journal Vol. 13, No.3, 2003: 193-218.

194. Turner, L. An anthropological exploration of contemporaries bioethics: the varieties of comoon sense. J Med Ethics. 1998 (24): 127-123.

195. Beauchamp TL, Childress JF. Op. cit.; 423.

196. DeGrazia D. Common morality, coherence, and the Principles of Biomedical Ethics. Kennedy Institute of Ethics Journal Vol. 13, No. 3, 2003; 407.

197. Brand-Ballard J. Consistency, common morality and reflective equilibirum. Kennedy Institute of Ethics Journal. Vol 13, No.3, 2003; 231-258.

198. Ibidem; 240.

199. Kukla R. Living with pirates. Common morality as embodied Practice, Cambridge Quaterly. 2014; 76-86.

200. Kelly-Herissone P. Determining the common morality's norms in the sixth edition of Principles of Biomedical Ethics. J of Med Ethics 2011. 37. 584-587.

201. Beauchamp TL, Childress JF. Op. cit.; 416-418.

202. Ibidem; 418.

203. Karlsen JR, Solbakk JH. A waste of time: the problem of common morality in Principles of Biomedical Ethics, J Med Ethics 2011 37; 588-591.

204. Holm S. Not just autonomy! The principles of American Bioethics. J Med Ethics 1995 21; 332-338. 
205. Garrafa V, Porto D. Bioética, poder e injustiça: por uma bioética de intervenção. In: Garrafa V, Pessini L. (Org) Bioética: poder e injustiça. 2. ed. Loyola, 2004; 35-44.

206. Ibidem; 40.

207. Ibidem; 39.

208. Ibidem; 42.

209. Engelhardt Jr, HT. Bioethics and secular humanism. The search for a common morality. Wipf and stock, Eugene Oregon. 2012; (1a ed. 1991)

210. Engelhardt Jr, HT. Foudations of Bioethics. 1996; 122-123.

211. Engelhardt Jr, HT. Op. cit.; 134.

212. Garrafa V, Porto D. Intervention Bioethics: A proposal for peripheral countries in a context of power and injustice. Bioethics 2003 (17) 5-6; 399-416.

213. Garrafa V. Porto D. Bioética de Intervención. In: Tealdi JC. (org) Diccionario latino-americano de bioética. Bogotá, RedBioética Unesco 2008; 161-164.

214. Garrafa V, Porto D. Op.cit.; 407.

215. Kottow M. Bioética prescritiva. A falácia naturalista. O conceito de princípios na bioética. In: Bases conceituais da bioética. Enfoque latino-americano. Garrafa V, Kottow M, Saada A. (Org). São Paulo: Gaia; 2006; 25-45.

216. Pettit P. Two sources of morality. Social Philosophy and Policy (18), 2001; 102-128.

217. Kottow M. Op. cit.; 29-30.

218. Kant I. Op. cit., 1997;69.

219. Kottow M. Op. cit.; 31.

220. Ibidem; 41.

221. Ibidem; 43.

222. Schramm FR, Kottow M. Principios bioéticos en salud pública: limitaciones y pro p u e s t a Cad. Saúde Pública, Rio de Janeiro, 17(4):949-956, 2001. 
223. Schramm FR. Bioética sem universalidade? Justificação de uma bioética latino-americana e caribenha de proteção. In: Bases conceituais da bioética. Enfoque latino-americano. Garrafa V, Kottow M, Saada A. (Org) São Paulo: Gaia; 2006; 143-157.

224. Ibidem; 156-157.

225. Tealdi JC. Os princípios de Georgetown: análise crítica. In: Bases conceituais da bioética. Enfoque latino-americano. Garrafa V, Kottow M, Saada A. (Org) São Paulo: Gaia; 2006; 49-63.

226. Basso SC. Comentário ao texto de Juan carlos Tealdi. In: Bases conceituais da bioética. Enfoque latino-americano. Garrafa V, Kottow M, Saada A. (Org) São Paulo: Gaia; 2006; 63-71.

227. Outka G e Reeder JP. Principles of Biomedical Ethics, In: Outka, G., Reeders, J.P. (Editors). Prospects for a Common Morality. Princeton University Press. Princeton, New Jersey, 1993.

228. Gewirth, A. Common morality and the community of rights. In: Outka, G., Reeders, J.P. (Editors). Prospects for a Common Morality. Princeton University Press. Princeton, New Jersey, 1993; 29-52.

229. Little, D. The nature and basis of human rights. In: Outka, G., Reeders, J.P. (Editors). Prospects for a Common Morality. Princeton University Press. Princeton, New Jersey, 1993; 73-92.

230. Baier, A.C. Claims, rights, responsibilities. In: Outka, G. Reeder, Jr., J.P. (Editors) Prospects for a Common Morality. Princeton University Press, Princeton, New Jersey, 1993;149-169.

231. Adams, R.M. Religious ethics in a pluralistic society. In: Outka, G., Reeders, J.P. (Editors). Prospects for a Common Morality. Princeton University Press. Princeton, New Jersey, 1993; 93-113.

232. Outka, G. Augustinianism and common morality. In: Outka, G., Reeders, J.P. (Editors). Prospects for a Common Morality. Princeton University Press. Princeton, New Jersey, 1993; 114-148. 
233. Donagan A. Common Morality and Kant's Enlightment Project. In: Outka, G., Reeders, JP. (Editors). Prospects for a Common Morality. Princeton University Press. Princeton, New Jersey, 1993; 53-72.

234. Adams, R.M. Op. cit.; 109.

235. Farley, MA. Feminism and Universal Morality. In: Outka, G., Reeders, J.P. (Editors). Prospects for a Common Morality. Princeton University Press. Princeton, New Jersey, 1993; 170-190.

236. Reeder Jr, J.P. Foundations without foudantionalism. In: Outka, G., Reeders, J.P. (Editors). Prospects for a Common Morality. Princeton University Press. Princeton, New Jersey, 1993; 191-214.

237. Stout, J. On having a morality in common. In: Outka, G., Reeders, J.P. (Editors). Prospects for a Common Morality. Princeton University Press. Princeton, New Jersey, 1993; 215-232.

238. Yearley LH. Conflicts among ideals of human flourishing. In: Outka, G., Reeders, J.P. (Editors). Prospects for a Common Morality. Princeton University Press. Princeton, New Jersey, 1993; 233-253.

239. Rorty, R. The priority of democracy to philosophy. In: Outka, G., Reeders, J.P. (Editors). Prospects for a Common Morality. Princeton University Press. Princeton, New Jersey, 1993; 254-278.

240. Brito NA. (Org) Op.cit.; 115.

241. Dewey, J. Human Nature and conduct. Barnes and Noble, New York, 2008; 43-48. 